\title{
The Arctic Summer Cloud Ocean Study (ASCOS): overview and experimental design
}

\author{
M. Tjernström ${ }^{1,2}$, C. Leck ${ }^{1,2}$, C. E. Birch ${ }^{3}$, J. W. Bottenheim ${ }^{4}$, B. J. Brooks ${ }^{3}$, I. M. Brooks ${ }^{3}$, L. Bäcklin ${ }^{1}$, R. \\ Y.-W. Chang ${ }^{5}$, G. de Leeuw ${ }^{6,7,8}$, L. Di Liberto ${ }^{9}$, S. de la Rosa ${ }^{10,11}$, E. Granath ${ }^{1}$, M. Graus ${ }^{12}$, A. Hansel ${ }^{12}$,

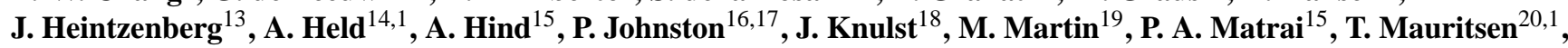 \\ M. Müller ${ }^{12}$, S. J. Norris ${ }^{3}$, M. V. Orellana ${ }^{21}$, D. A. Orsini ${ }^{13}$, J. Paatero ${ }^{6}$, P. O. G. Persson ${ }^{16,17}$, Q. Gao ${ }^{1}$, \\ C. Rauschenberg ${ }^{15}$, Z. Ristovski ${ }^{22}$, J. Sedlar ${ }^{23,1}$, M. D. Shupe ${ }^{16,17}$, B. Sierau ${ }^{19}$, A. Sirevaag ${ }^{11,24}$, S. Sjogren ${ }^{25}$, \\ O. Stetzer $^{19}$, E. Swietlicki ${ }^{25}$, M. Szczodrak ${ }^{26}$, P. Vaattovaara ${ }^{27}$, N. Wahlberg ${ }^{1}$, M. Westberg ${ }^{1}$, and C. R. Wheeler ${ }^{16}$ \\ ${ }^{1}$ Department of Meteorology, Stockholm University, Stockholm, Sweden \\ ${ }^{2}$ Bert Bolin Centre for Climate Research, Stockholm University, Stockholm, Sweden \\ ${ }^{3}$ Institute for Climate \& Atmospheric Science, School of Earth and Environment, University of Leeds, Leeds, UK \\ ${ }^{4}$ Environment Canada, Toronto, Canada \\ ${ }^{5}$ Department of Chemistry, University of Toronto, Toronto, Canada \\ ${ }^{6}$ Finnish Meteorological Institute, Helsinki, Finland \\ ${ }^{7}$ Department of Physics, University of Helsinki, Helsinki, Finland \\ ${ }^{8}$ TNO Environment and Geosciences, Dept. of Air Quality and Climate, Utrecht, the Netherlands \\ ${ }^{9}$ Institute of Atmospheric Sciences and Climate (ISAC) of the Italian National Research Council, Rome, Italy \\ ${ }^{10}$ Nansen Environmental and Remote Sensing Center, Bergen, Norway \\ ${ }^{11}$ Geophysical Institute, University of Bergen, Bergen, Norway \\ ${ }^{12}$ Institute of Ion Physics and Applied Physics, University of Innsbruck, Innsbruck, Austria \\ ${ }^{13}$ Leibniz Institute for Tropospheric Research, Leipzig, Germany \\ ${ }^{14}$ University of Bayreuth, Bayreuth Center of Ecology and Environmental Research, Bayreuth, Germany \\ ${ }^{15}$ Bigelow Laboratory for Ocean Sciences, East Boothbay, ME, USA \\ ${ }^{16}$ Cooperative Institute for Research in Environmental Science (CIRES), University of Colorado, Boulder, CO, USA \\ ${ }^{17}$ National Oceanic and Atmospheric Administration, Physical Sciences Division, Boulder, CO, USA \\ ${ }^{18}$ BNR Ecotour Consulting AB, Lammhult, Sweden \\ ${ }^{19}$ Institute for Atmospheric and Climate Science, ETH Zürich, Zürich, Switzerland \\ ${ }^{20}$ Max Planck Institute for Meteorology, Hamburg, Germany \\ ${ }^{21}$ Institute for Systems Biology, Seattle, WA, USA \\ ${ }^{22}$ School of Physical and Chemical Sciences, Queensland University of Technology, Brisbane, Australia \\ ${ }^{23}$ Swedish Meteorological and Hydrological Institute, Norrköping, Sweden \\ ${ }^{24}$ Bjerknes Centre for Climate Research, Bergen, Norway \\ ${ }^{25}$ Division of Nuclear Physics, Lund University, Lund, Sweden \\ ${ }^{26}$ Rosenstiel School of Marine and Atmospheric Sciences, University of Miami, Miami, FL, USA \\ ${ }^{27}$ Department of Applied Physics, University of Eastern Finland, Kuopio, Finland
}

Correspondence to: C. Leck (lina@misu.su.se) and M. Tjernström (michaelt@misu.su.se)

Received: 15 March 2013 - Published in Atmos. Chem. Phys. Discuss.: 23 May 2013

Revised: 14 November 2013 - Accepted: 13 January 2014 - Published: 19 March 2014 
Abstract. The climate in the Arctic is changing faster than anywhere else on earth. Poorly understood feedback processes relating to Arctic clouds and aerosol-cloud interactions contribute to a poor understanding of the present changes in the Arctic climate system, and also to a large spread in projections of future climate in the Arctic. The problem is exacerbated by the paucity of research-quality observations in the central Arctic. Improved formulations in climate models require such observations, which can only come from measurements in situ in this difficult-to-reach region with logistically demanding environmental conditions.

The Arctic Summer Cloud Ocean Study (ASCOS) was the most extensive central Arctic Ocean expedition with an atmospheric focus during the International Polar Year (IPY) 2007-2008. ASCOS focused on the study of the formation and life cycle of low-level Arctic clouds. ASCOS departed from Longyearbyen on Svalbard on 2 August and returned on 9 September 2008. In transit into and out of the pack ice, four short research stations were undertaken in the Fram Strait: two in open water and two in the marginal ice zone. After traversing the pack ice northward, an ice camp was set up on 12 August at $87^{\circ} 21^{\prime} \mathrm{N}, 01^{\circ} 29^{\prime} \mathrm{W}$ and remained in operation through 1 September, drifting with the ice. During this time, extensive measurements were taken of atmospheric gas and particle chemistry and physics, mesoscale and boundarylayer meteorology, marine biology and chemistry, and upper ocean physics.

ASCOS provides a unique interdisciplinary data set for development and testing of new hypotheses on cloud processes, their interactions with the sea ice and ocean and associated physical, chemical, and biological processes and interactions. For example, the first-ever quantitative observation of bubbles in Arctic leads, combined with the unique discovery of marine organic material, polymer gels with an origin in the ocean, inside cloud droplets suggests the possibility of primary marine organically derived cloud condensation nuclei in Arctic stratocumulus clouds. Direct observations of surface fluxes of aerosols could, however, not explain observed variability in aerosol concentrations, and the balance between local and remote aerosols sources remains open. Lack of cloud condensation nuclei (CCN) was at times a controlling factor in low-level cloud formation, and hence for the impact of clouds on the surface energy budget. ASCOS provided detailed measurements of the surface energy balance from late summer melt into the initial autumn freezeup, and documented the effects of clouds and storms on the surface energy balance during this transition. In addition to such process-level studies, the unique, independent ASCOS data set can and is being used for validation of satellite retrievals, operational models, and reanalysis data sets.

\section{Introduction}

A primary goal for the Arctic Summer Cloud Ocean Study (ASCOS) is to provide observations to facilitate a better understanding of the formation and life cycle of the summer Arctic Ocean low-level clouds, with an overarching aim to improve formulations in climate models. To achieve this, we followed the development of biological, chemical and physical processes in the ocean, ice and atmosphere during the late summer melt season, which is also the most biologically active period in the central Arctic, and into the transition to autumn freeze-up. ASCOS was deployed in the central Arctic Ocean on the Swedish icebreaker Oden during late summer 2008 as part of the International Polar Year (IPY); ASCOS was the most extensive central Arctic project with an atmospheric focus during IPY.

Climate change is faster in the Arctic than in any other region on earth (IPCC, 2007; ACIA, 2005; Richter-Menge and Jeffries, 2011). Arctic near-surface temperatures are rising at a rate at least twice that of the global average temperature, and Arctic sea ice is declining in all seasons, most dramatically in summer (e.g., Lindsay and Zhang, 2005; Serreze et al., 2007; Overland, 2009). Many other aspects of Arctic climate change show an "Arctic amplification" (Serreze and Francis 2006; Serreze and Barry, 2011). The debate over the primary processes responsible for the Arctic amplification is reflected in the scientific literature: changes in large-scale atmospheric circulation patterns (e.g., Graversen, 2006; Graversen et al., 2008; Overland et al., 2009; Zhang et al., 2008; Kapsch et al., 2013), radiative forcing due to changes in greenhouse gases (Serreze et al., 2007; Graversen and Wang., 2009), inflow of warm ocean water (e.g., Shimada, 2006; Polyakov et al., 2007) or a mixture of these. Although no consensus exists as to the primary causes, it is likely that the Arctic amplification is related to one or more of several powerful feedbacks in the Arctic climate system, for example the ice-albedo feedback (Perovich et al., 2008) and cloud-radiative characteristics (Liu et al., 2008; Kay et al., 2008; Kay and Gettelman, 2009). Attribution is further complicated by the fact that processes constituting a feedback in a global context could be considered an external forcing in a regional setting.

Climate modeling is an indispensable tool in the understanding of the complex climate system. However, state-ofthe-art global climate models have significant problems with the Arctic climate (Walsh et al., 2002; Chapman and Walsh, 2007), and the inter-model spread in climate scenarios for the end of this century in, for example, the Intergovernmental Panel on Climate Change Fourth Assessment Report (IPCCAR4) is the largest in the Arctic (Holland and Bitz, 2003). This large spread is due to a combination of a large inherent variability and modeling uncertainties due to poor understanding of feedback mechanisms within the Arctic climate system (e.g., Sorteberg et al., 2005). 
The potential effects of Arctic clouds on climate lie at the heart of this discussion (Liu et al., 2008; Kay et al., 2008; Kay and Gettelman, 2009). Clouds remain an Achilles' heel in our understanding of the climate system and consequently in climate modeling (e.g., IPCC, 2007, 2013), representing one of the largest sources of uncertainty in understanding the present and projecting the future climate (e.g., IPCC, 2007). The global climate sensitivity in different models to an altered greenhouse gas forcing is tightly linked to how they represent low-level marine clouds and their response to a warmer climate (e.g., Stephens 2005). Arctic clouds are a particular problem (Walsh et al., 2002; Tjernström et al., 2008; Karlsson and Svensson, 2011), and model evaluations show discouraging results both for global (Walsh et al., 2002; Karlsson and Svensson, 2011) and regional models (e.g., Tjernström et al., 2005, 2008). Many global models fail to obtain even the annual cycle of cloud fraction correct, not to mention more subtle factors such as altitude or amounts and phase of condensate in Arctic clouds (e.g., Karlsson and Svensson, 2011).

Low-level clouds are ubiquitous in the Arctic, especially during the summer, with cloud fractions as high as 80-90\% (Curry and Ebert, 1992; Intrieri et al., 2002a; Wang and Key, 2005; Tjernström, 2005; Shupe et al., 2011; Zygmuntowska et al., 2012). These clouds have a substantial effect on the surface energy budget (e.g., Intrieri et al., 2002b; Sedlar et al., 2011) and thus on melting and freezing of the perennial sea ice (Kay and Gettelman, 2009). In contrast to similar clouds at lower latitudes, low-level central Arctic clouds tend to warm the surface relative to clear conditions during most of the year, due to an intricate balance between cloud optical properties and the highly reflecting surface (e.g., Intrieri et al., 2002b; Shupe and Intrieri, 2004; Sedlar et al., 2011). For large parts of the year, the surface reflectivity is as high as, or higher than, the cloud albedo, and longwave radiation processes dominate. During the most intense summer ice melt, surface reflectivity is reduced when melting sea ice opens up dark ocean surfaces and melt ponds form on the ice. Lowlevel clouds may therefore cool the surface for a short time period in summer (Intrieri et al., 2002b).

Tjernström et al. (2008) documented the effects of systematic problems with the cloud representations in regional models on model surface radiation. They found deficits in incoming longwave radiation and solar radiation at the surface, in winter and summer respectively. They considered several possibilities and suggested that winter problems were due to a lack of liquid water in modeled winter clouds, whereas summer problems were due to an overestimation of optical thickness of summer clouds. In both cases, aerosol conditions in the Arctic could be responsible. While the formation of clouds primarily depends on the prevailing meteorological conditions, optical properties of clouds are determined by both micro- and macrophysical properties. The microphysical properties of clouds are strongly affected by the fraction of the aerosol particles capable of acting as cloud condensation nuclei $(\mathrm{CCN})$ or ice-forming nuclei (IN).

In winter, the large-scale atmospheric circulation facilitates an inflow into the Arctic of anthropogenic pollution from the south. When this is reinforced by photochemical oxidation at polar sunrise, the result is the well-known "Arctic haze" (Heintzenberg, 1989; Shaw et al., 1989). In contrast, summer conditions are much more pristine (e.g., Garrett et al., 2010) with low aerosol concentrations, typically $<150 \mathrm{~cm}^{-3}$ and occasionally $<1 \mathrm{~cm}^{-3}$ (Lannefors et al., 1983; Covert et al., 1996; Bigg et al., 1996; 2001; Heintzenberg and Leck, 2012). The low concentration of aerosol particles is also borne out by frequently very good subcloud visibility, with no or very little subcloud haze even with very low cloud-base heights (Tjernström et al., 2004a, 2012). The paucity of aerosol particles may be a contributing factor in the high frequency of occurrence of optically thin clouds compared to other regions. These clouds have fewer, but larger, cloud droplets and are very sensitive to changes in aerosol conditions. In shortwave radiation, optically thin clouds are less effective at reflecting solar radiation back to space (e.g., Twomey, 1977) while for longwave radiation they may become "grey" (i.e., emit less thermal radiation than a corresponding blackbody). The low concentration of $\mathrm{CCN}$ can even result in episodes when clouds do not form due to the absence of sufficient CCN (Bigg et al., 1996, 2001; Mauritsen et al., 2011).

Low concentration of $\mathrm{CCN}$ also promotes frequent light precipitation, which is often frozen. The almost constant presence of frozen precipitation is indicative of so-called mixed-phase clouds, referring to a system where a thin layer of super-cooled liquid water at the cloud top continuously precipitates ice particles (e.g., Shupe et al., 2008). This situation, where the conditions are highly super-saturated with respect to ice, is unstable because ice particles will grow at the expense of liquid water droplets. However, formation of new ice crystals is sufficiently slow to allow for continued maintenance of cloud liquid water by in-cloud processes (e.g., Morrison et al., 2012). This limited formation of cloud ice is due, in part, to low IN concentrations in the very clean Arctic air. Since regional anthropogenic impacts are limited, biologically derived $\mathrm{CCN}$ and IN sources from the open ocean in the marginal ice zone (MIZ) and in open leads may play a larger role (Leck and Bigg, 1999, 2005a, b; Leck et al., 2002; Orellana et al., 2011). If this is the case, the aerosol life cycle over the perennial Arctic pack ice will have implications for cloud formation and phase partitioning in central Arctic low-level clouds and thus for the surface energy balance and the formation of sea ice.

Cloud formation occurs on the subgrid scale in numerical models of the atmosphere. Therefore, instead of simulating clouds directly they must be modeled as functions of variables - and processes - resolved on the model grid: in other words be parameterized. Developing and improving cloud parameterizations involves theoretical considerations 
but ultimately relies on closure assumptions derived from observations, typically from ensembles of observation campaigns with detailed measurements of cloud processes. We speculate that the poor model performance in the Arctic is at least partly an effect of a deficiency in such field work: the vast majority of all cloud-process studies are conducted at lower latitudes, in very different climate regimes. It will not be possible to resolve cloud parameterization problems without an understanding of the processes involved. Moreover, testing of new cloud schemes tailored to central Arctic conditions must be conducted against data from the Arctic. The only solution to these problems must include observations of clouds and cloud-related processes taken directly from the central Arctic Ocean. To understand the effects of aerosol particles on the cloud optical properties and any possible climate feedbacks of these processes, it is also important to understand the sources and concentrations of central Arctic Ocean atmospheric aerosol particles. The utility of campaigns such as ASCOS thus primarily lies in enhancing the understanding of important processes and thereby contributing to improved modeling.

Whereas most of the dramatic temperature increase in the Arctic has been observed in the cold seasons, with no or limited solar radiation, more attention is now turning to summer. In summer the presence of melting snow and ice at the surface effectively limits near-surface warming above the melting point, although some studies indicate warming aloft (Graversen et al., 2008); in areas where ice completely melts away, however, substantial surface warming occurs. As more ice and snowmelt, more solar radiation penetrates into the ocean causing significant upper-ocean warming, which in turn affects the autumn freeze-up since all this extra heat must be returned to the atmosphere before ice freezes again. This may allow effects of the ice melt and snowmelt during summer to be carried over into following seasons (e.g., Overland et al., 2011).

This paper describes the ASCOS field campaign. ASCOS was the latest in a series of expeditions to the central Arctic Ocean on the Swedish icebreaker Oden to study Arctic summer clouds: the International Arctic Ocean Expedition in 1991 (IAOE-91, Leck et al., 1996; here Oden became the first non-nuclear powered vessel to reach the North Pole) and the Arctic Ocean Experiments in 1996 (AOE-96, Leck et al., 2001) and 2001 (AOE-2001, Leck et al., 2004; Tjernström et al., 2004a). These atmospheric studies in the central Arctic Ocean, north of $80^{\circ} \mathrm{N}$, started with a small group and limited resources in 1991 and has since grown to a large international multidisciplinary consortium. ASCOS spent over a month in the North Atlantic sector of the central Arctic Ocean in summer 2008. The main effort was a 3-week ice-drift operation around $\sim 87^{\circ} \mathrm{N}$ with the icebreaker moored to a drifting ice floe during the most biologically active period and into autumn freeze-up conditions (mid-August through early September). Figure 1 shows the track of the expedition; the inset shows the ice drift in detail.

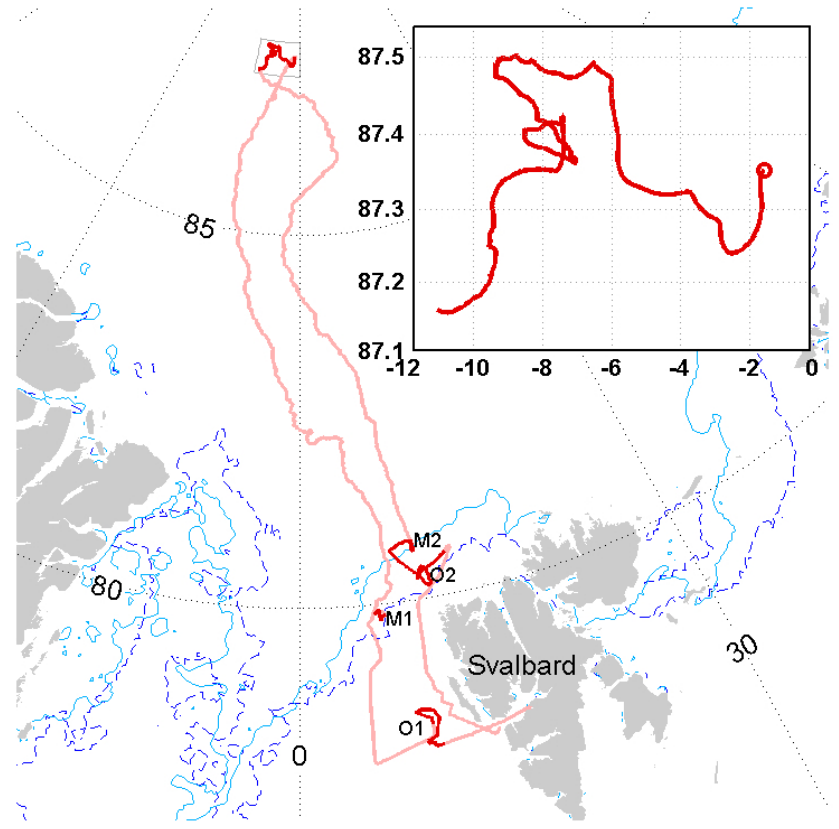

Fig. 1. Plot of the cruise track (red) also showing the track of the ice drift (inset). The left-hand part of the track shows the initial northward track while the right-hand track shows the southward return track. Convoluted track lines in open water $(\mathrm{O} 1$ and $\mathrm{O} 2)$ and at the ice edge (M1 and M2) are associated with shorter sampling stations. The dashed blue line illustrates the ice edge at the time of entry and exit.

This paper presents the scientific background to ASCOS in Sect. 2, followed by a discussion of the necessary scientific information needed in Sect. 3. This forms the basis for observation design considerations in Sect. 4 , followed by a brief description of the route and conditions encountered in Sect. 5. Sampling platforms, instruments and experimental logistics are described in Sect. 6, followed by a summary of some results in Sect. 7 and a discussion in Sect. 8. A detailed description of the instrumentation is given in Appendix A.

\section{Scientific background of ASCOS}

ASCOS is a continuation and development of successful research carried out during three previous international icebreaker expeditions to the summer central Arctic Ocean on the Swedish icebreaker Oden. The scientific motivation, however, goes back further.

The Ymer-80 expedition (Lannefors et al., 1983) to the MIZ around Svalbard included the first attempts to measure Arctic Ocean summer aerosol particles and trace gases. The results indicated low aerosol concentrations over the Arctic Ocean. Around this time, Charlson et al. (1987) proposed that remote oceanic $\mathrm{CCN}$ originated from dimethyl sulfide (DMS), a gas released from the uppermost ocean as zooplankton graze on phytoplankton. Analogies with a 
strong seasonality in DMS production at other locations (e.g., in the Baltic Sea; Leck et al., 1990) suggested that a secondary summer peak in aerosol concentrations observed at Ny-Ålesund on Spitsbergen (Heintzenberg, 1989) might be due to oxidation products of DMS: sulfur dioxide, sulfuric and methane sulfonic acids $\left(\mathrm{SO}_{2}, \mathrm{H}_{2} \mathrm{SO}_{4}\right.$ and MSA). Given that sulfate was a major end product in aerosol particles in the MIZ from Ymer-80, it seemed reasonable that $\mathrm{SO}_{2}, \mathrm{H}_{2} \mathrm{SO}_{4}$ and MSA could be important for new particle formation and evolution, and therefore $\mathrm{CCN}$, over the Arctic Ocean.

During IAOE-91 it was found that DMS oxidation products were major precursor components of $\mathrm{CCN}$-sized particles observed over the pack ice (Leck and Persson, 1996a). The DMS source was found predominantly in the MIZ (Leck and Persson, 1996b), although local DMS production over pack ice was negligible. The main control of DMS over the ice-covered central Arctic Ocean is thus biological activity in the MIZ and oceans south thereof. This was consistent with the hypothesis that $\mathrm{H}_{2} \mathrm{SO}_{4}-\mathrm{H}_{2} \mathrm{O}$ nucleated particles (nucleation mode, 3-25 nm diameter; see Covert et al. (1996) for definitions) are formed as DMS-rich air, and its oxidation products are advected in over the Arctic Ocean. Subsequently these particles would grow to accumulation mode (ca $100 \mathrm{~nm}$ diameter) by further condensation of $\mathrm{H}_{2} \mathrm{SO}_{4}$ and MSA, and activate to CCN. However, fog and low clouds in the MIZ cause a rapid scavenging and removal of particles entering over the pack ice (Nilsson 1996), and the results from IAOE91 thus suggested a local aerosol source in the central Arctic Ocean.

AOE-96 aimed to study the aerosol particles in more detail, in particular to investigate a potential local aerosol source within the pack ice. A first ice drift was launched; a manned ice camp was deployed on the ice and left to operate for a week (Leck et al., 2001). The number of observed nucleation events was larger than in 1991, mostly in air that had resided over the pack ice for at least 4 days. Again, nucleation mode particles were usually accompanied by particles in distinct size ranges between 10 and $50 \mathrm{~nm}$ diameter (Leck and Bigg, 1999). To test the hypothesis that they consisted of $\mathrm{H}_{2} \mathrm{SO}_{4}$, they were examined by electron microscopy. Surprisingly, these very small particles, below $50 \mathrm{~nm}$ diameter, were not composed of $\mathrm{H}_{2} \mathrm{SO}_{4}$ (Bigg and Leck, 2001; Leck and Bigg, 1999). Instead, they mostly consisted of five- or six-sided water insoluble solids, resembling viruses or marine biogenic colloidal nanogels. These were often accompanied by larger micrometer-sized colloidal gels that can aggregate to several hundred $\mu \mathrm{m}$ (macrogels), and by bacteria and fragments of diatoms. Gels, also referred to as polymer gels or marine gels, are produced by phytoplankton and sea ice algae biological secretions. These polymer molecules are non-water-soluble, highly surface-active and highly hydrated ( $99 \%$ water) polymer saccharide molecules. They form three-dimensional networks, inter-bridged with divalent ions to which other organic compounds, such as proteins and lipids, are readily bound (Decho, 1990; Zhou et al.,
1998; Chin et al., 1998; Xin et al., 2013; for a review see Verdugo, 2012). Moreover, the importance of the local meteorology for particle concentrations and variability has become obvious (Bigg et al., 1996, 2001).

These results lead to the AOE-2001, with the icebreaker Oden moored to an ice floe for a 3-week ice drift, deploying enhanced meteorology and marine biology programs. The first measurements of particulate material from the surface microlayer of the ocean (SML; the $<100 \mu$ m-thick surface film on the open ocean between the ice floes; Knulst et al., 2003) were taken. There were strong indications that polymer gels existed also in the atmosphere and that their source was the SML (Bigg et al., 2004; Leck and Bigg 2005a, b).

Many aspects of the low-level clouds, the boundary layer and surface energy balance were also explored, using shipborne surface-based remote-sensing and micrometeorological measurements on the ice (Tjernström, 2004a). Surface fluxes were dominated by radiation, and turbulent fluxes were small. However, the effect of the low-level clouds on the surface remained a cooling one even in summer (Tjernström, 2005). The boundary layer was usually shallow, and the turbulent mixing was dominated by buoyancy-produced cloud overturning, but the cloud layer was often decoupled from the surface. Tjernström (2007) also indicated a significant diurnal cycle in the cloud layer, while the corresponding cycle near the surface was small. Tjernström and Mauritsen (2009) found frequent mesoscale fronts propagating in the boundary layer. Sometimes these mesoscale features triggered buoyancy waves propagating in the wave guide set up by the boundary-layer capping inversion; some of these waves were breaking, and this enhanced the vertical mixing. In contrast to most other climate regimes, specific humidity very often increased across the inversion that capped the boundary layer (Tjernström, 2005, 2007), and entrainment into the boundary layer therefore was a source rather than a sink of boundary-layer moisture, contributing to a very moist environment. Also, boundary-layer cloud tops were not capped by the inversion; rather the top of the clouds usually penetrated into the inversion (Tjernström, 2007; Sedlar and Tjernström, 2009).

These three expeditions have contributed to improved understanding of summer Arctic-specific aerosol and cloud formation processes, and the effects of clouds on the surface energy budget, and generated new conceptual pictures of the vertical structure and surface effects of the clouds. A previously unknown marine biological source of Arctic aerosol particles was found, and a new hypothesis on the evolution of the aerosol particles over the central Arctic Ocean was developed: primary-produced polymer gels can act as $\mathrm{CCN}$ directly, due to the strong surface-active properties of the gels. After aging in the atmosphere, gels may still act as sites for condensation of oxidation products from DMS. This is suggested by the detection of water-insoluble marine gels in most collected particles (50-90\% of the total number; Leck and Bigg, 2005a) and by the detected gel 
inclusions within predominantly sulfate particles (Leck and Bigg, 2005b). Such acquisition of sulfuric acid on primary particles would provide a more direct and faster path to $\mathrm{CCN}$ status, compared to growth from nucleated particles. DMS concentration thus determines the mass of the particles, by producing material for their growth, but the number of airborne microgels influences the number of $\mathrm{CCN}$, and thus the resulting optical properties of clouds. This suggests a stronger possible link between marine biology, cloud properties and climate than provided by DMS alone (Leck and Bigg, 2007). But many questions still remain:

- How large is the contribution of local marine biogenic sources of CCN or IN, compared to transport of aerosol particles and precursors from outside the central Arctic, and how efficient are they as $\mathrm{CCN}$ and/or IN?

- How can primary marine biogenic particles be transferred from the ocean surface microlayer into the atmosphere, and how does this depend on oceanic and atmospheric properties?

- How are aerosol particles transported and transformed in the atmospheric boundary layer and inside the clouds?

- How efficient is the exchange between the surface and the free troposphere where other aerosols or aerosol precursors may exist, and what are the effects on the clouds by this exchange?

- What meteorological conditions favor the formation of optically thin clouds?

- How do the clouds affect their own environment and the surface energy balance?

ASCOS was developed to address these questions.

\section{What observations are needed to improve under- standing?}

Two basic criteria must be fulfilled for clouds to form, each necessary but neither sufficient: relative humidity near saturation and the presence of appropriate aerosol particles to serve as CCN or IN. This far, the problem appears trivial; however the system is very complicated involving interactions on many scales and requires a deeper interdisciplinary understanding.

So what do we need to know to improve our understanding of cloud processes and provide appropriate cloud descriptions for numerical climate models, and what types of observations does this require? Here we outline the important disciplinary and interdisciplinary themes that were the focus of ASCOS.
- Formation of cloud droplets or ice crystals requires the local relative humidity to be sufficiently high, due to either high absolute humidity or low temperature or both, so that the specific humidity is close to or higher than saturation.

Cloud formation is constrained by a combination of large- and small-scale atmospheric motions. For example vertical transport, in convection or in frontal zones, is a critical condition for cloud formation while turbulent motions provide mixing and vertical transport of momentum, heat, humidity and particles to and from the surface and also between the free atmosphere and the boundary layer. Large-scale atmospheric circulation also determines the transport of air from potential source regions outside of the Arctic and controls its residence time over the pack ice.

We therefore need to monitor the evolving conditions in the large-scale atmosphere as well as atmospheric turbulence near the surface, through the boundary layer and inside the clouds. We also need to observe the vertical structure of different atmospheric variables (temperature, humidity and winds) to determine the mechanisms behind local mixing and whether clouds are coupled to surface processes or not. We also need to estimate the magnitude of entrainment from the free troposphere to the boundary layer.

- Formation of cloud droplets or ice crystals requires the presence of aerosol particles, with either a watersoluble component beyond a critical mass (CCN) or ice-forming characteristics (IN).

This necessitates assessing the multi-component and multi-phase nature of airborne aerosol particles and a consideration that chemical properties usually differ with size, and even among individual particles within a given size range. This requires observations of sizeresolved aerosol number, state of mixture, morphology, surface tension and solubility. The only method presently available to determine chemical properties, morphology and state of mixture of individual particles down to $10 \mathrm{~nm}$ in diameter is electron microscopy. However, this method is not fully quantitative and obtaining statistics of the proportion of particles that have a particular property is highly time-consuming. To enhance the quantitative information of particulate chemistry, an additional approach is recommended, using size-segregated bulk mass detection of a wide spectrum of organic water-soluble and water-insoluble components. To enhance the temporal resolution of the aerosol chemical observations, measurements of the hygroscopic properties of the particles using a Hygroscopic Tandem Differential Mobility Analyzer (HTDMA) could be applied. This approach would serve as an indirect chemical measure but at a relatively high 
temporal resolution $(\sim 30 \mathrm{~min})$, in contrast to the 6$48 \mathrm{~h}$ sampling necessary for the bulk chemical determination. Moreover, to show the potential effects of aerosol recycling in clouds or fog and differences in composition between the surface and cloud base, it is necessary to determine the chemical and physical properties of particles collected from cloud and fog water.

- Cloud particles, whether droplets or ice crystals, are continuously lost to the surface by sedimentation or precipitation (e.g., drizzle or snow). CCN and/or IN are therefore continuously lost, implying a necessity for replenishment of particles.

We therefore need to monitor the formation of new particles (nucleation) and investigate potential particle sources. Nucleation is energetically difficult; particles formed by nucleation of $\mathrm{H}_{2} \mathrm{SO}_{4}$ and water vapor require days to weeks to grow to $100 \mathrm{~nm}$ by further gas-to-particle conversion, although more efficient growth can occur in cloud droplets. Hygroscopic particles, such as sea salt or organic matter with strong surface active properties, take up water at relative humidity $(\mathrm{RH})<100 \%$ and are the first to form droplets as the humidity increases; if numerous they may prevent less efficient $\mathrm{CCN}$ from activation. Once droplets are formed, gaseous compounds such as $\mathrm{SO}_{2}$ and ammonia can dissolve into them and undergo aqueousphase oxidation. When droplets evaporate, larger particles form as a result of the additional oxidized material. Repeated cycling through clouds facilitates the development of the accumulation-mode peak in the aerosol size spectrum. In addition to formation of accumulation-mode particles through growth, primary particles derived from bubble bursting at the air-water interface can be directly injected into this mode (de Leeuw et al., 2011; Leck et al., 2002). In this process, bubbles scavenge debris and high molecular weight soluble organic surface-active compounds, such as microgels, rising through the water column prior to injection into the atmosphere (Bigg and Leck, 2008). Their highest number occurs at the upper end of the accumulation mode, bypassing the need to grow particles before they can act as $\mathrm{CCN}$.

We therefore need to monitor the evolution of aerosol resolved over size and their chemical and morphological properties. As previous Oden expeditions indicated a marine primary biological particle source of particles from the surface microlayer in open-water leads (Leck et al., 1996, 2002; Leck and Bigg, 1999; Bigg and Leck, 2001; Kerminen and Leck, 2001; Heintzenberg et al., 2006; Heintzenberg and Leck, 2012; Lohman and Leck, 2005), we need to sample the microlayer itself as well as the chemistry, biology and physics of the upper ocean. We also need to explore potential transfer mechanisms from ocean to atmosphere, for example, by measuring bubble formation in the upper ocean (Bigg and Leck, 2008) and aerosol fluxes to and from the surface (Nilsson and Rannik, 2001). We also need to understand aerosol loss processes (i.e., precipitation and wet deposition).

- Gases potentially available to condense on primary marine biogenic and inorganic particles can either be generated locally or be transported to the Arctic with the large-scale flow. CCN-sized particles can, given time, be mixed with other constituents primarily through the uptake of condensable vapors, such as secondary organics and DMS oxidation products from the gas phase (Karl et al., 2012). Therefore timecontinuous as well as profiling observations of both aerosol particles and condensable vapors are important.

For gas and tracer chemistry, characterization of DMS and acetonitrile, as tracers for marine and continental sources respectively, combined with sampling of atmospheric radioactive isotopes (e.g., ${ }^{210} \mathrm{~Pb},{ }^{222} \mathrm{Rn}$ and ${ }^{7} \mathrm{Be}$ ), is needed. Together with trajectory calculations and analysis of weather systems, this provides information on air mass origin and therefore on potential source regions contributing to the atmospheric composition.

- An understanding of the impact of clouds on the climate system as well as the sensitivity of the clouds to their environment is the overarching goal of ASCOS.

We need to simultaneously monitor both macro- and microphysical characteristics of the clouds, and their impact on the energy fluxes at the surface and on the vertical structure of the lower atmosphere. As cloud radiative properties are potentially sensitive to $\mathrm{CCN}$ and IN concentrations, we need to monitor not only the clouds and their characteristics (cloud boundaries, cloud water phase, amount of cloud water and number of cloud particles) but also the simultaneous aerosol population, as well as the turbulent and radiative heat fluxes at the surface and through the boundary layer, and thus also the boundary layer structure.

\section{Sampling considerations and limitations - ASCOS experimental design and strategy}

From the list of observational needs outlined in the previous section, it is clear that an effort to address these requires an interdisciplinary approach. ASCOS was therefore designed with contributions from experts in several disciplines: synoptic-scale and boundary-layer meteorology, atmospheric 

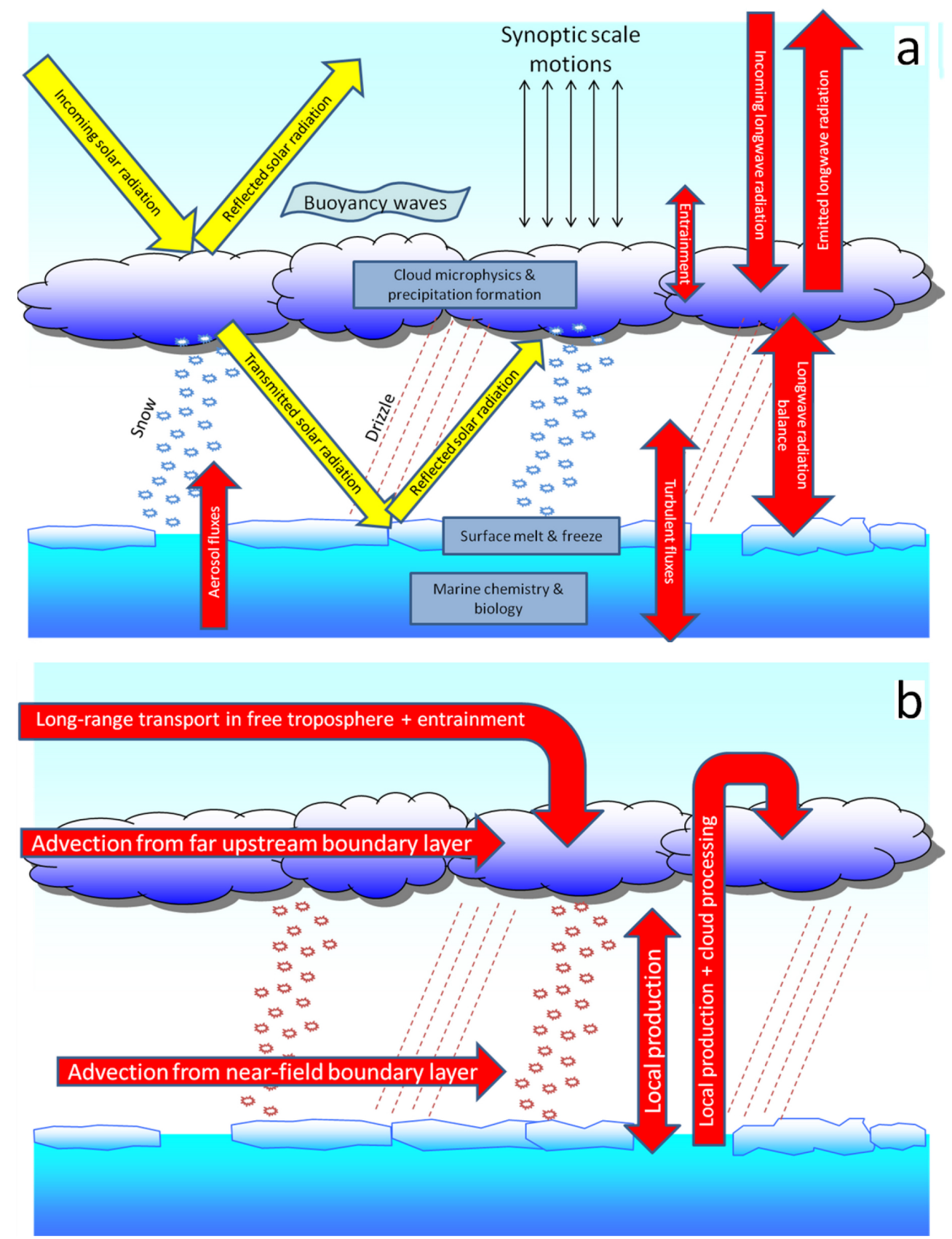

Fig. 2. Schematic description of processes that are necessary to observe in order to understand the formation and life cycle of Arctic low-level clouds, illustrating (a) the processes at play and (b) specifically the aerosol formation processes.

gaseous and particulate phase chemistry and physics, marine chemistry and biology, and physical oceanography. Some of the necessary measurements can, or must, be made in situ while for others there are alternatives. Some can be made by instruments deployed on board an icebreaker, whereas others need to be performed in an undisturbed environment.

Clearly the observational needs that motivated ASCOS far outweighed what was possible to realistically obtain. Ideally, all observations should be carried out in three dimen- sions with a high temporal resolution; in reality this is seldom possible. In the atmosphere, the largest gradients are found in the vertical. Slower-evolving horizontal gradients manifest themselves as temporal variations as air masses or boundaries between air masses (frontal zones) - are advected past a fixed-point observer. Although the atmosphere changes character as it moves over the surface, such temporal changes in a Lagrangian framework are usually slower than spatial changes; these are manifested as temporal changes in 
an Eulerian sense. The main compromise was therefore to focus on high temporal resolution observations in a single vertical column. This was accomplished by deploying multiple observation systems that track various aspects of the system from the upper $500 \mathrm{~m}$ of the ocean, through the air-sea interface and the lowest atmosphere, up through the free troposphere and into the lower stratosphere, with a focus on the lower parts of the atmosphere. Sampling rates were different for different variables, ranging from $10 \mathrm{~Hz}$ for the turbulence observations, over seconds and minutes - for clouds and gaseous compounds, some aerosol physics and surface heat fluxes - to a few samples per day for marine chemistry and biology, and aerosol chemical composition. The sampling strategy in each case was determined by a combination of the scientific requirements and practical considerations.

Vertical profiling of several parameters is part of the requirements listed above, especially considering the multilayered structure of Arctic low-level clouds (e.g., Curry et al., 1996; Intrieri et al., 2002a). In particular for linking aerosol particles and gases measured on the ship to properties and processes in the clouds, profile observations are indispensable. Therefore the icebreaker's helicopter was equipped with aerosol particle counters, a gas-sampling system and sensors for basic meteorology. However, while the Arctic low-level clouds were the scientific target for ASCOS, they also pose an air-safety concern. The clouds typically contain super-cooled liquid water, and aircraft icing is a concern. Moreover, as suitable landing aids were not available, flying on instrument flight rules through or above clouds was impossible. This restricted helicopter flights to visual flight rules, and we resorted to flying profiling missions in short breaks in the low cloud cover, assuming that conditions during such short intermissions were broadly representative of conditions immediately before and after. In situ observations of cloud microphysics were not possible for the same reasons. Instead, an extensive suite of surface-based remote-sensing instruments were deployed on board the ship. While not providing the kind of detail possible with in situ sampling, this provided continuous and simultaneous high temporal- and vertical-resolution information on cloud micro and macrophysics characteristics typically not available with in situ techniques. Further profiling information during a few episodes was gained through a sister project: the Arctic Mechanisms for the Interaction of the Surface and Atmosphere (AMISA, Persson, 2010) project, flying instruments on the National Aeronautic and Space Administration's (NASA) DC-8 research aircraft, based out of Kiruna, Sweden. The DC-8 has effective anti-icing capacity allowing in-cloud flights.

Continuous observation of turbulent fluxes through the clouds was also impractical, since the height of the tallest mast that could be erected on the ice was limited. Instead we deployed a tethered lifting system based on a heliumfilled SkyDoc aerostat lofting a turbulence package from the surface to $\sim 700 \mathrm{~m}$. Flying step-wise in altitude allowed ade- quate sampling of turbulence at different heights, although not simultaneously. Slow ascents/descents provided turbulence profile information using the highest frequency observations and turbulence similarity relationships, although turbulent fluxes cannot be directly recovered this way. Additionally, the tethered system was equipped with an aerosol instrument and was also used to sample bulk cloud water for later laboratory analysis. Some turbulence information could also, under certain conditions, be derived from the cloud radar (Shupe et al., 2012).

Figure 2a schematically illustrates the multitude of processes that need to be observed, while Fig. $2 b$ outlines some of the potential aerosol formation and transport paths. In summary we need characterization of nutrients, productivity and microbiology in the ocean water and ocean surface microlayer, to quantify the aerosol fluxes to and from the surface, long records with detailed observations of the chemical and physical properties of the aerosol resolved over size, trace-gas concentrations, cloud-active particles (CCN and IN), and radioactive tracers. Also, detailed continuous observations of macro- and microphysical properties of the clouds and of atmospheric motions on all scales need to be made, from vertical mixing by turbulence to long-range transport by larger-scale atmospheric flow, and of the energy fluxes at the surface.

Shipboard observations are a challenge (e.g., Leck et al., 2001; Brooks et al., 2009). Observations of exchange processes near the surface are sensitive to flow distortion around the superstructure of the ship. Some instruments are sensitive to the environment on board (heat transfer, hydraulic noise, vibrations, obstacles, etc.). This necessitated deployment of such instrumentation away from the ship, on the ice. The size and scope of many of these instruments preclude short-term deployments, necessitating an ice-drift strategy with the ship moored to a drifting ice floe. This in turn requires a sufficiently thick and stable ice floe.

In the pristine Arctic environment, gases and aerosol particles must be sampled with minimum interference from the ship and from human activity on the surface immediately surrounding the ship. Measurements of aerosols challenge the detection limits of even the most sophisticated laboratory instruments. Sufficient mass had to be collected for a proper analysis, and in pristine Arctic conditions this takes time (Leck and Persson, 1996b); even brief contamination during a long sampling period can destroy the whole sample. Therefore, a procedure to detect and avoid contamination by the ship or activity on the ice must be established together with methods to automatically interrupt sampling when necessary, due to unfavorable conditions. Because of the sampling sector restrictions, we also require the ship to be approximately facing into the wind. For the ice drift this necessitated finding, or making, a "harbor" in the ice where the ship can be moored in several main orientations, and turned as the wind direction changed. Turning of the ship would unfortunately have consequences for the power supply to instruments on 

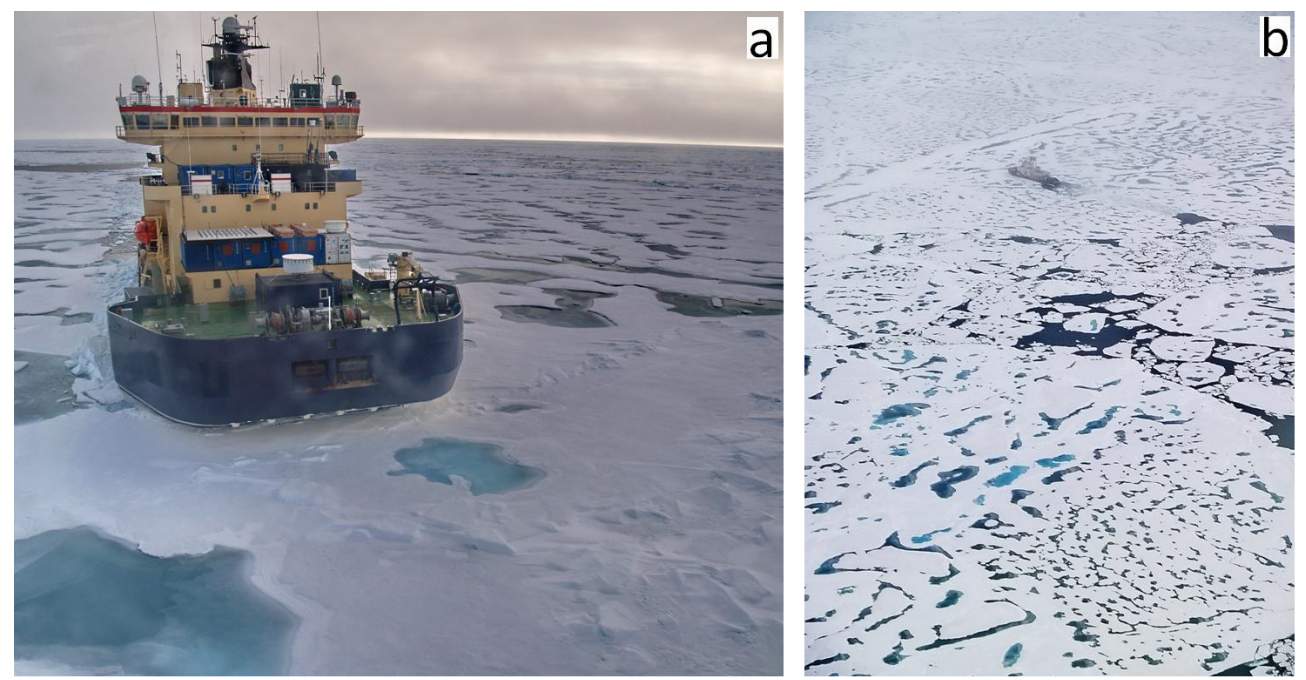

Fig. 3. Photographs from 11 August, 2008, of the icebreaker Oden (a) from the front, and (b) from above embedded in a large ice floe. Note the numerous melt ponds on the ice. Both photographs were taken somewhat south of $87^{\circ} \mathrm{N}$.

the ice; hence instruments on the ice need to be battery powered, continuously charged through battery chargers fed by a power cable from the ship. Power could then be temporarily interrupted without affecting the measurements on the ice.

Similar contamination constraints apply for the marine chemical and biological observations. Although Oden has an advanced system for waste management and minimizes environmental impacts, the presence of a ship in the water always means a risk of contaminated water samples. Turning of the ship also disturbs the water column in its immediate vicinity. Therefore, marine sampling had to be performed from the ice away from the ship, with a safe access to the ice edge. This also implies transporting equipment and staff across the ice on a daily basis. Instruments and computers at that site had to rely entirely on battery power, since the distance precluded powering by cable from the ship.

Finally, the harsh Arctic environment, with sometimes low temperatures and always high relative humidity, affects both instruments and people. Because of these conditions, there is a need for instrument redundancy. Many instrument systems therefore had to be doubled and some even tripled. Risks involved in operating with people on the ice, also the natural habitat for polar bears, would affect the use of instrument systems that need continuous manual intervention. Some systems, for example the marine biological, oceanographic, atmospheric tethered measurements and the determination of bulk chemical mass, are labor-intensive, and manpower on an Arctic expedition is limited by the number of berths on board the ship, which also has limiting effects on some observations.

Processing the list of requirements through what is practical, a set of logistics requirements emerge. In summary, the need to perform observations on location in the Arctic with heavy, expensive and power-consuming equipment, and to house and feed a large scientific staff far away from any permanent base, required access to a large platform such as an icebreaker. The need for undisturbed conditions for some of the observations requires access to a reasonably large and safe ice floe, also with consequences for the sampling strategy, how instruments are powered and the need for transport; work on the ice also has safety implications. Finally, the need for vertical profiling required access to airborne platforms; however, the inability of the ship's helicopter to fly in clouds also required deployment of a tethered platform and of a suite of remote-sensing instruments.

It is worth noting that, although these concerns were carefully considered in the planning, it was not until the expedition was launched on site in the central Arctic Ocean that specific conditions could be determined. It thus fell upon the chief scientists, the captain of the icebreaker and the whole science team to be flexible and adapt.

\section{The expedition - route and conditions encountered}

ASCOS was deployed on the Swedish icebreaker Oden, a diesel-powered, $108 \mathrm{~m}$-long and $24500 \mathrm{hp}$ vessel, built in 1987 to assist commercial shipping and for science missions. Oden is very effective in the Arctic, breaking $2 \mathrm{~m}$-thick ice continuously at a speed of 3 knots. Figure 3 a shows a photograph of the icebreaker Oden from the bow, while Fig. 3b shows Oden embedded in pack ice with many melt ponds; both photos were taken from the ship's helicopter during an ice reconnaissance mission on the evening of 11 August 2008. 
Table 1. List of abbreviations.

\begin{tabular}{|c|c|}
\hline Abbreviation & Explanation \\
\hline APS & Aerodynamic particle sizer \\
\hline ATOFMS & Aerosol time-of-flight mass spectrometer \\
\hline $\mathrm{BC}$ & Black carbon or light-absorbing carbon at $\lambda=550 \mathrm{~nm}$ \\
\hline $\mathrm{BCI}$ & Berner cascade impactor \\
\hline $\mathrm{CCN}$ & Cloud condensation nuclei \\
\hline CCNC & Continuous-flow stream-wise thermal gradient $\mathrm{CCN}$ counter \\
\hline CLASP & Compact Lightweight Aerosol Spectrometer Probe \\
\hline $\mathrm{CPC}$ & Condensation particle counter \\
\hline CTD & Conductivity-temperature-depth probe \\
\hline C-ToF-AMS & Compact time-of-flight aerosol mass spectrometer \\
\hline$D_{50}$ & The lognormal distribution median diameter \\
\hline DIA & Digital image analysis \\
\hline DMA & Differential mobility analyzer \\
\hline DMS & Dimethyl sulfide \\
\hline DMSP & Dimethyl sulfonium propionate \\
\hline DOC & Dissolved organic carbon \\
\hline DOM & Dissolved organic matter \\
\hline EAD & Aerodynamic diameter \\
\hline EGF & Ethanol growth factor \\
\hline FESEM & Field emission scanning electron microscopy \\
\hline FP & Filter pack cassette \\
\hline FSSP & Forward Scatter Spectrometer Probe \\
\hline GC/FID & Gas chromatograph/flame ionization detector \\
\hline GPS & Global positioning system \\
\hline Grimm-EDM & Grimm model EDM 180 Environmental dust monitor \\
\hline HRGC-HRMS & High-resolution gas chromatography/high-resolution mass detector \\
\hline HPLC/FD & High-performance liquid chromatography/fluorescence detection \\
\hline H-TDMA & Hygroscopic tandem differential mobility analyzer \\
\hline IC & Ion chromatography \\
\hline ICP-MS & Ion-coupled plasma mass spectrometry \\
\hline IN & Ice nuclei \\
\hline LC-MS/MS & Liquid chromatography/tandem mass spectrometry \\
\hline Lidar & Light detection and ranging \\
\hline LPI & Low-pressure impactor \\
\hline M-AERI & Marine-Atmospheric Emitted Radiance Interferometer \\
\hline MAXDOAS & Multi-Axes Differential Optical Absorption Spectrometer \\
\hline MIZ & Marginal ice zone \\
\hline MMCR & Millimeter-wavelength Cloud Radar \\
\hline MSA & Methane sulfonic acid \\
\hline NMHC & Non-methane hydrocarbons \\
\hline $\mathrm{OPC}$ & Optical particle counter \\
\hline OOTI & "Out on the ice", autonomous chemical observation package \\
\hline PAR & Photosynthetically active radiation \\
\hline PCASP & Passive cavity aerosol spectrometer \\
\hline PCMB & Polycarbonate membrane filters \\
\hline PINC & Portable ice nucleation chamber \\
\hline $\mathrm{PM}_{1}$ & Particle mass below $1 \mu \mathrm{m}$ in diameter \\
\hline $\mathrm{PM}_{10}$ & Particle mass below $10 \mu \mathrm{m}$ in diameter \\
\hline $\mathrm{POC}$ & Particulate organic carbon \\
\hline PON & Particulate organic nitrogen \\
\hline POP & Particulate organic phosphorous \\
\hline PSi & Particulate organic silica \\
\hline PTR-TOFMS & Proton transfer reaction time of flight mass spectrometer \\
\hline Radar & Radio detection and ranging \\
\hline SEM & Scanning electron microscope \\
\hline SFU & Stacked filter unit \\
\hline SMPS & Scanning mobility particle sizer \\
\hline Sodar & Sound detection and ranging \\
\hline
\end{tabular}


Table 1. Continued.

\begin{tabular}{ll}
\hline Abbreviation & Explanation \\
\hline TDMA & Tandem differential mobility analyzer \\
TEM & Transmission electron microscope \\
TD & Thermodenuder \\
TIC & Turbulence instrument cluster \\
TN & Total nitrogen \\
TOC & Total organic carbon \\
TSP & Total suspended particulate matter \\
TDMPS & Twin differential mobility particle sizer with a TD \\
TPTZ & 2,4,6-tripyridyl-s-triazine \\
UFO-TDMA & Ultrafine organic tandem differential mobility analyzer \\
UDMPS & Ultrafine differential mobility particle sizer \\
UDMA & Ultrafine differential mobility analyzer \\
UCPC & Ultrafine condensation particle counter \\
UV & Ultraviolet radiation \\
V-TDMA & Volatile tandem differential mobility analyzer \\
VH-TDMA & Volatile and hygroscopic tandem differential mobility analyzer \\
VOCs & Volatile organic compounds \\
\hline
\end{tabular}

Table 2. Participating groups with respective acronyms.

\begin{tabular}{|c|c|}
\hline Institute & Abbreviation \\
\hline Department of Meteorology, Stockholm University, Stockholm, Sweden & MISU* \\
\hline Bigelow Laboratory for Ocean Sciences, East Boothbay, Maine, USA & BLOS \\
\hline Cooperative Institute for research in the Environmental Studies, University of Colorado, and National & CIRES/NOAA \\
\hline \multicolumn{2}{|l|}{ Oceanographic and Atmospheric Administration's Earth System Research Laboratory, Boulder, Colorado, USA } \\
\hline Department of Chemistry, University of Toronto, Toronto, Canada & DCUT \\
\hline Science and Technology Branch, Environmental Canada, Toronto, Canada & EC \\
\hline Department of Nuclear Physics, Lund University, Lund, Sweden & LU \\
\hline Department of Applied Physics, University of Eastern Finland, Kuopio, Finland & UEF \\
\hline ETH Technical University, Zürich, Switzerland & ETH \\
\hline Finnish Meteorological Institute, Helsinki, Finland & FMI \\
\hline Department of Physics, University of Helsinki, Helsinki, Finland & UoH \\
\hline TNO Environment and Geosciences, Dept. of Air Quality and Climate, Utrecht, the Netherlands & TNO \\
\hline Geophysical Institute, University of Bergen, Bergen, Norway & GFI \\
\hline Institute for Climate \& Atmospheric Science, School of Earth and Environment, University of Leeds, Leeds, UK & LEEDS \\
\hline Institute for Ion Physics and Applied Physics, Environmental Physics and & IIPAP \\
\hline \multicolumn{2}{|l|}{ Ion-Molecule-Reactions, University of Innsbruck, Innsbruck, Austria } \\
\hline Institute of Systems Biology, Seattle, Washington, USA & ISB \\
\hline Institute for Tropospheric Research, Leipzig, Germany & IFT \\
\hline Rosenstiel School of Marine and Atmospheric Sciences, University of Miami, Miami, Florida, USA & RSMAS \\
\hline Queensland University of Technology, Brisbane, Australia & QUT \\
\hline CNR, Earth and Environment Department, Institute for Atmospheric Sciences and Climate, Rome, Italy & ISAC ${ }^{* *}$ \\
\hline Department of Homeland Security, Environmental Measurements Laboratory, USA & DHS** \\
\hline Norwegian Institute for Air Research, Oslo, Norway & NILU** \\
\hline Norwegian Polar Institute, Troms $\varnothing$, Norway & NPI** \\
\hline
\end{tabular}

* Project and expedition coordination;

** Participated with instrument only.

ASCOS departed from Longyearbyen on Spitsbergen on 2 August (DoY ${ }^{1}$ 205) and returned in the early morning of

\footnotetext{
${ }^{1}$ Decimal day-of-year defined so that DoY $=1.0$ is on 1 January at 00:00 UTC.
}

9 September (DoY 245) 2008. Figure 1 shows the track of Oden during ASCOS: measurements began with an openwater station in the Greenland Sea on 3 August 00:00 to 12:00 UTC $\left(\sim 78^{\circ} 10^{\prime} \mathrm{N}, 07^{\circ} 30^{\prime} \mathrm{E}\right)$ followed by a $24 \mathrm{~h}$ station in the MIZ starting on 4 August at $12: 00 \mathrm{UTC}\left(\sim 79^{\circ} 55^{\prime} \mathrm{N}\right.$, 


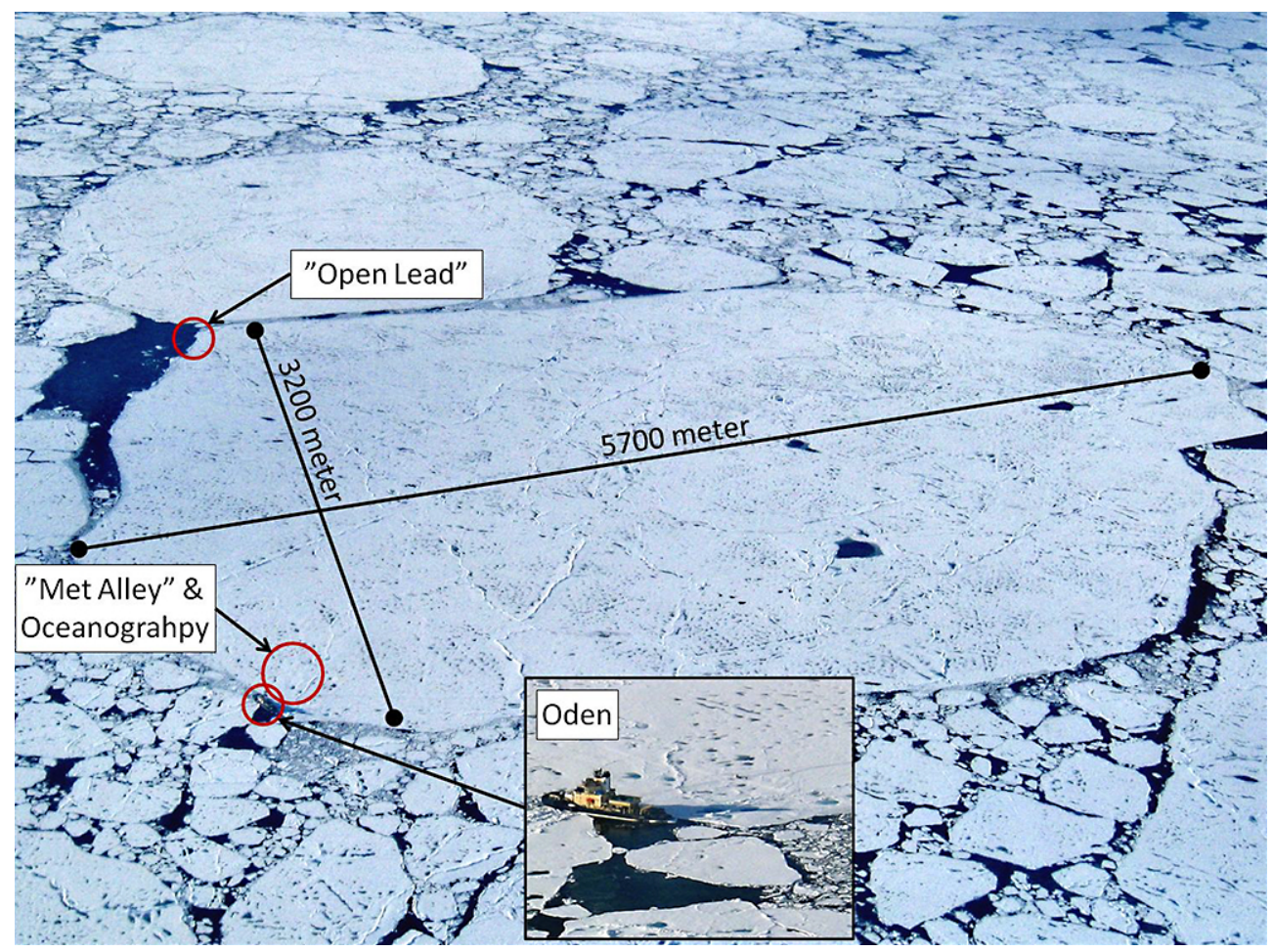

Fig. 4. Aerial photograph from 26 August of the ice floe used for the ice drift, from 12 August through 1 September. The ice floe was approximately $3 \mathrm{~km}$ by $6 \mathrm{~km}$ in size; Oden can be seen in the lower left corner of the floe. Most of the boundary-layer and physical oceanography measurements were taken in the vicinity of the ship. At this location the ice was $2-8 \mathrm{~m}$ thick, and a local $\sim 120^{\circ}$ corner in the floe allowed mooring of the ship in four main directions. The marine biology and chemistry site, also with aerosol flux observations, was located some $\sim 3 \mathrm{~km}$ away from the ship in the upper left corner in the photograph.

$\left.06^{\circ} 06^{\prime} \mathrm{E}\right)$. Oden then headed north through the pack ice for the most intensive measurement period: the ice drift that commenced on 12 August. The ship was moored to an ice floe at $87^{\circ} 21^{\prime} \mathrm{N}, 01^{\circ} 29^{\prime} \mathrm{W}$ and drifted for 21 days to $87^{\circ} 09^{\prime} \mathrm{N} 11^{\circ} 01^{\prime} \mathrm{W}$; the return journey commenced at 04:00 UTC on 2 September. The inset in Fig. 1 shows the ice drift in detail. A second MIZ station started on 6 September 09:00 UTC and continued to 7 September 04:00 UTC $\left(\sim 80^{\circ} 40^{\prime} \mathrm{N}, 08^{\circ} 55^{\prime} \mathrm{E}\right)$, before a final $12 \mathrm{~h}$ open-water station was launched on 7 September, starting at 04:00 UTC $\left(\sim 80^{\circ} 25^{\prime} \mathrm{N}, 10^{\circ} 05^{\prime} \mathrm{E}\right)$.

Finding a sufficiently stable ice floe for the ice drift was a major concern, in particular given the loss of thicker multiyear ice (e.g., Kwok et al., 2009) and the preceding summer's "record" ice melt (e.g., Comiso et al., 2008). Daily ice-cover maps derived from satellite data were provided by the University of Bremen (George Heygster, 2008, personal communication) in a specially tailored format. Substantial areas of reasonably thick ice were found approaching $87^{\circ} \mathrm{N}$; however, the ice had poor integral structure with many melt ponds (see Fig. 3b), some quite deep, broke easily, and did not withstand attempts to break a harbor for the icebreaker (see discussion above).
After airborne ice reconnaissance, during which the photographs in Fig. 3 were taken, it was decided to continue north, and on the morning of 12 August an ice floe was found north of $87^{\circ} \mathrm{N}$ that was selected for the ice drift (Fig. 4). As soon as the thickness and stability of the ice floe were ascertained, deployment of the instrument systems started, and by afternoon all equipment had been flown out using helicopter sling loads and pulled into place by snowmobile, and the installations started. By that evening the logistics at the "Open Lead" site were deployed, and the deployment of the masts on the ice had begun (see Fig. 4 for locations). Adverse weather, with strong winds on the afternoon on 12 August, continued through most of the next day (Tjernström et al., 2012) and delayed deployment by at least a day, but by 15 August the majority of the installations were completed. The tear-down of the ice camp was initiated on the evening of 31 August; all instruments were on board again by the evening of 1 September.

Except for in the MIZ, ice cover was mostly $>80 \%$, occasionally close to $100 \%$. The ice was typically around $2 \mathrm{~m}$ thick (estimated from overturned ice floes during ice breaking) and covered by numerous melt ponds. By the time Oden departed the ice floe in the early morning on 2 September, however, all water surfaces, leads as well as melt ponds, were 


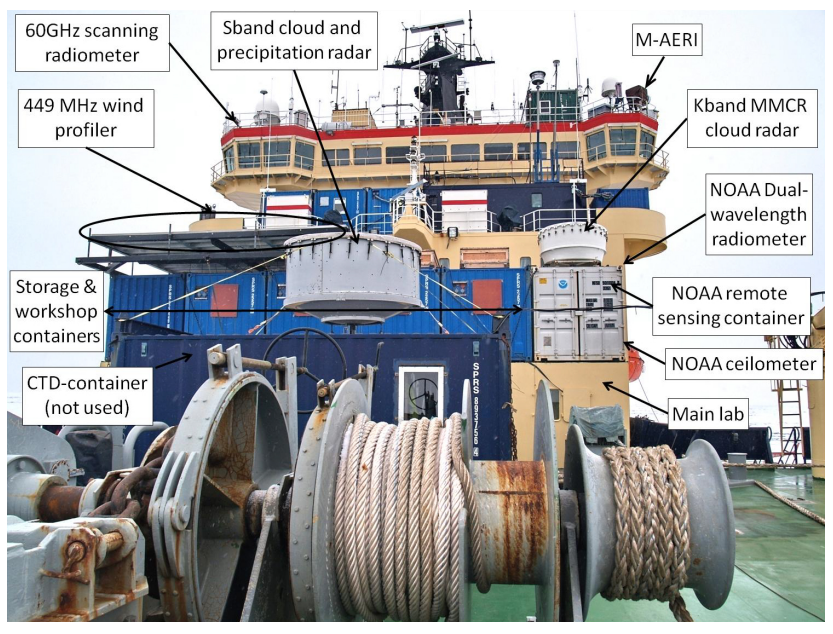

Fig. 5. Photograph from Oden's foredeck showing the location of the surface-based remote-sensing systems. The dual-wavelength radiometer and the NOAA ceilometer are obscured behind the remote-sensing container.

frozen over. Thus the aim of spanning from the late melt season to the initial transition to autumn freeze-up was fulfilled. Upper ocean temperature remained almost constant at about $-1.8^{\circ} \mathrm{C}$ down to a depth of about $100 \mathrm{~m}$, while the salinity was slightly above 32 psu in a $\sim 30 \mathrm{~m}$-deep mixed layer (Sirevaag et al., 2011). Near-surface air temperatures varied mostly in the -2 to $0{ }^{\circ} \mathrm{C}$ interval, constrained by the melting points of fresh and ocean water, respectively, although lower temperatures appeared, especially towards the end of the ice drift when temperature started to drop. Near-surface relative humidity was mostly $>90 \%$, and there were long periods where the air was supersaturated with respect to ice. The sky was mostly overcast with clouds, and fog was relatively frequent, while visibility outside of fog was usually $>20 \mathrm{~km}$. Meteorological conditions encountered are summarized in Tjernström et al. (2012). The sun was above the horizon for almost the entire expedition; the first sunset was experienced on 6 September on the way back to Svalbard.

\section{Platforms and instruments}

ASCOS utilized three main instrument platforms: the icebreaker Oden, the ice floe, and the ship's helicopter. A summary of the participating groups and the instrumentation deployed during ASCOS is provided in Tables 2 and 3, respectively; Table 4 outlines the temporal availability of observations from instruments or groups of instruments. A detailed description of instruments is given in Appendix A.

\subsection{The icebreaker Oden}

The main platform for ASCOS was the icebreaker Oden (Fig. 3); Fig. 5 shows more details of the instrumentation,

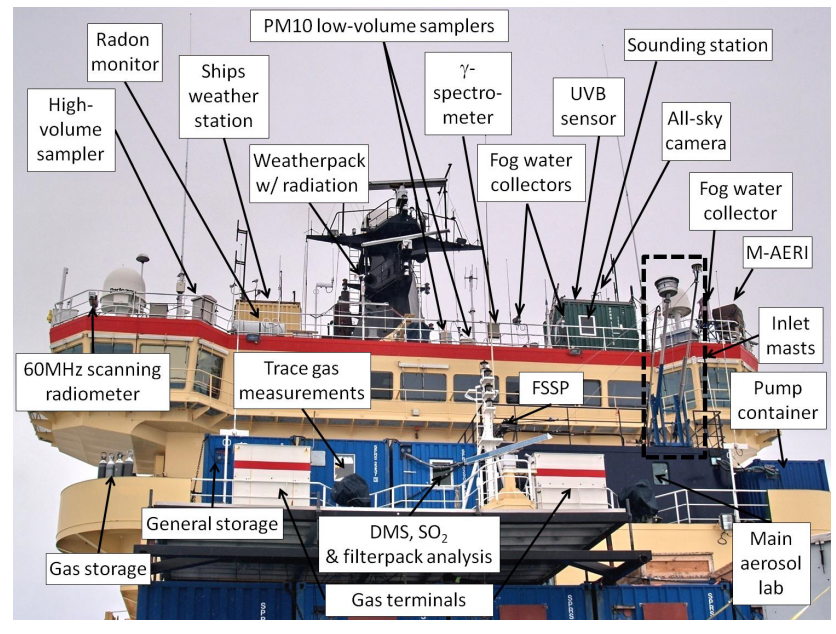

Fig. 6. Photograph of the installations on Oden's fourth and seventh decks. On the fourth deck the large aerosol container to the right with the sampling inlets on the roof is seen, with the two trace gas containers in the middle. To the far right is the common pump container, holding the pumps for all instruments. The two small containers of the upper seventh deck hold the ship's weather station (yellow to the left) and the sounding station (green to the right), both also holding electronics and computers for many of the other instruments. The scanning microwave radiometer is on the far left, the secondary weather station in the middle, and the M-AERI on the far right. Lined up along the front railing are a multitude of aerosol and fog water sampling instruments, and the radon monitor.

seen from the front of Oden. Two rows of containers are visible. The lower row of containers, on the roof of the permanent laboratory, housed the remote-sensing laboratory (white container on the far port side), workshops and storage. Two cloud-radar antennas are visible on the foredeck; the S-band cloud and precipitation radar is mounted on the roof of the CTD container, while the Ka-band Millimeter-wavelength Cloud Radar is located on the roof of the NOAA remotesensing container. The large antenna for the phased-array radar wind-profiler is seen to the left, on top of the lower row of containers. Also included in this suite of instruments were a laser ceilometer and a dual-wavelength microwave radiometer located by the remote-sensing container, but hidden from view in Fig. 5, and the $60 \mathrm{GHz}$ scanning radiometer and the Marine-Atmospheric Emitted Radiance Interferometer (M-AERI) on the seventh upper deck.

The upper row of containers, on the fourth deck, housed most of the physical and chemical aerosol and gas-phase chemistry measuring systems, in three laboratory containers. Facing forward from the aerosol container (far right in Fig. 6), the sampling manifold for gases and aerosol particles can be seen, extending at an angle of $45^{\circ}$ to about $3 \mathrm{~m}$ above the container roof to optimize the distance both from the sea and from the ship's superstructure. The height of the sampling manifold was $\sim 25 \mathrm{~m}$ above sea level, and it consisted of two hollow masts, with one additional sampling line 
Table 3. Measurement overview; see Table 1 for abbreviations and Table 2 for the participants' acronyms.

\begin{tabular}{|c|c|c|}
\hline Instrument system & Sensors and variables & Responsible partner \\
\hline \multicolumn{3}{|l|}{ Meteorology and atmospheric physics } \\
\hline Oden's weather station & $\begin{array}{l}\text { Air temperature, relative humidity, wind speed and direction both true } \\
\text { and relative to the ship, atmospheric pressure, visibility and cloud base }\end{array}$ & MISU \\
\hline WeatherPak & $\begin{array}{l}\text { Air temperature, relative humidity, wind speed and direction both true } \\
\text { and relative to the ship, atmospheric pressure, incoming short- and } \\
\text { longwave radiation, incoming PAR }\end{array}$ & RSMAS \\
\hline UV radiation & NILU-UV multiband filter radiometer & FMI \\
\hline Additional miscellaneous observation systems & $\begin{array}{l}\text { Visibility, "present weather", precipitation intensity, cloud base, UV } \\
\text { radiation, PAR, cosmic radiation }\end{array}$ & FMI/NILU \\
\hline Radiosoundings & $\begin{array}{l}\text { Temperature, relative humidity, pressure and wind speed and direction } \\
\text { as a function of altitude }\end{array}$ & MISU, FMI \\
\hline Tethered sounding system & Turbulent winds, temperature, humidity, aerosol size spectra & LEEDS \\
\hline \multicolumn{3}{|l|}{ Surface-based remote sensing: } \\
\hline MMCR Ka-band cloud radar & Active vertically pointing radar, reflectivity, Doppler velocity spectra & CIRES/NOAA \\
\hline S-band cloud and precipitation radar & Active vertically pointing radar, reflectivity, Doppler velocity spectra & CIRES/NOAA \\
\hline $449 \mathrm{MHz}$ wind profiler & $\begin{array}{l}\text { Active phased-array radar, signal-to-noise ratio, vertical profiles of } \\
\text { wind speed and direction }\end{array}$ & CIRES/NOAA \\
\hline $60 \mathrm{GHz}$ scanning microwave radiometer & Passive scanning microwave radiometer, profiles of temperature & CIRES/NOAA \\
\hline Dual-wavelength radiometer & Passive radiometer, vertically integrated water vapor and liquid water & CIRES/NOAA \\
\hline Cloud ceilometer & Active, laser, cloud base of liquid clouds & CIRES/NOAA/FMI \\
\hline Sodar & $\begin{array}{l}\text { Active phased array sound pulses, reflected echo structure (convertible } \\
\text { to turbulence properties), Doppler 3-D wind speed profile }\end{array}$ & LEEDS \\
\hline Fourier transform infrared interferometer (M-AERI) & $\begin{array}{l}\text { Passive radiometer, high-resolution frequency-resolved sky brightness } \\
\text { temperature, surface and air temperature }\end{array}$ & RSMAS \\
\hline MuLID micro-lidar & active lidar with depolarization & ISAC \\
\hline \multicolumn{3}{|l|}{ Micrometeorology (“Met Alley”) } \\
\hline $\begin{array}{l}\text { Turbulence (sonic anemometers, fine-wire thermocou- } \\
\text { ple, LI-COR Open path analyzers) }\end{array}$ & $\begin{array}{l}\text { Mean wind-speed profiles, high-frequency } 3 \text {-D winds and (sonic) tem- } \\
\text { perature, turbulence, momentum, sensible and latent hear fluxes, } \mathrm{CO}_{2} \\
\text { flux }\end{array}$ & MISU/LEEDS \\
\hline Thermocouple strings, heat flux plates & $\begin{array}{l}\text { Temperature profile in the lowest atmosphere and in the ice, surface } \\
\text { temperatures }\end{array}$ & MISU \\
\hline Ventilated radiation shielded temperature/humidity & Absolute temperature and relative humidity & MISU \\
\hline Broadband radiometers & Up- and downward short- and longwave radiation & MISU \\
\hline \multicolumn{3}{|l|}{ Micrometeorology ("Open Lead") } \\
\hline $\begin{array}{l}\text { Sonic anemometers, LI-COR open-path gas analyzer, } \\
\text { CPC particle counter }\end{array}$ & $\begin{array}{l}\text { High-frequency 3-D winds and (sonic) temperature, turbulence, mo- } \\
\text { mentum, sensible and latent hear fluxes and } \mathrm{CO}_{2}\end{array}$ & LEEDS/MISU \\
\hline \multicolumn{3}{|l|}{ Atmospheric chemistry } \\
\hline \multicolumn{3}{|l|}{ Gas and tracer chemistry characterization } \\
\hline HPLC/FD & Sulfur dioxide ( $\mathrm{SO}_{2}$, ship) & MISU \\
\hline UV absorption (Dasibi and Environment s/a analyzer) & Ozone $\left(\mathrm{O}_{3}\right.$, ship and "Open Lead") & MISU/FMI/EC \\
\hline $\begin{array}{l}\text { Atomic absorption instrument (Gardis) and MAX- } \\
\text { DOAS }\end{array}$ & Mercury and Bromine oxide (BrO and $\mathrm{Hg}$, "Open Lead") & $\mathrm{EC}$ \\
\hline PTR-TOF-MS & $\begin{array}{l}\text { Volatile organic compounds (VOCs), dimethyl sulfide (DMS), ace- } \\
\text { tonitrile, acetone; various pollution markers (e.g., benzene, toluene, } \\
\text { xylene), ship sampling as well as analysis of helicopter flask samples }\end{array}$ & IIPAP \\
\hline Automatic alpha/beta analyzer & ${ }^{210} \mathrm{~Pb}(\mathrm{p})$ & FMI \\
\hline Semiconductor gamma spectrometry & ${ }^{7} \mathrm{Be}$ & FMI \\
\hline Geiger counters & Radioactivity soundings & FMI \\
\hline Electrochemical sensor & Ozone soundings & FMI \\
\hline DHS/EML Beast & ${ }^{222} \mathrm{Rn}(\mathrm{g})$ & FMI/DHS \\
\hline Steel-canisters/GC-FID & NMHC (e.g., propane and butane, ship) & FMI \\
\hline \multicolumn{3}{|l|}{ Aerosol chemistry aerosol } \\
\hline Precipitator/SEM/TEM; ATOFMS & $\begin{array}{l}\text { Single particle chemical composition } \\
\left(D_{50}: 10 \mathrm{~nm}-3 \mu \mathrm{m}\right)\end{array}$ & MISU, ETH \\
\hline CAHN-microbalance & $\begin{array}{l}\text { Aerosol gravimetric mass distribution } \\
\left(D_{50}<10 \mu \mathrm{m} \text { and } D_{50}<1 \mu \mathrm{m}\right)\end{array}$ & MISU \\
\hline LC-MS/MS; SEM/TEM & Saccharides, amino acids, proteins, microgels $\left(D_{50}: 25 \mathrm{~nm}-10 \mu \mathrm{m}\right)$ & MISU, BLOS, ISB \\
\hline $\mathrm{BCI} / \mathrm{LPI} / \mathrm{SFU} / \mathrm{IC}$ & Major soluble ions $\left(D_{50}: 25 \mathrm{~nm}-10 \mu \mathrm{m}\right)$ & MISU \\
\hline Photometer detection of light absorption at $\lambda=550 \mathrm{~nm}$ & Non-refractory chemical mass $\left(D_{50}: 70 \mathrm{~nm}-0.7 \mu \mathrm{m}\right)$ & MISU \\
\hline C-ToF-AMS & Non-refractory chemical mass $\left(D_{50}: 70 \mathrm{~nm}-0.7 \mu \mathrm{m}\right)$ & DCUT \\
\hline LC-MS/MS; SEM/TEM & $\begin{array}{l}\text { Bubble generated nascent particulate matter: saccharides, amino } \\
\text { acids, proteins, microgel abundance }\left(D_{50}<1 \mu \mathrm{m} \text {, ship }\right)\end{array}$ & MISU \\
\hline GC/FID detector & Polycyclic aromatic hydrocarbons (e.g., PAH) & FMI \\
\hline \multicolumn{3}{|l|}{$\begin{array}{l}\text { Atmospheric aerosol - physical and cloud-active prop- } \\
\text { erties }\end{array}$} \\
\hline Aerosol size distribution & Number density $\left(D_{50}: 3 \mathrm{~nm}-10 \mu \mathrm{m}\right)$ & FMI, IFT, MISU \\
\hline $\mathrm{CCN}$ and IN & Number density & LU, ETH \\
\hline Droplet size distribution & $\operatorname{FSSP}\left(D_{50}: 1-47 \mu \mathrm{m}\right)$ & FMI \\
\hline Cloud active properties & Number density fractions $\left(D_{50}: 20 \mathrm{~nm}-1 \mu \mathrm{m}\right)$ & LU, UEF, QUT, IFT \\
\hline Eddy covariance & Aerosol fluxes over water and ice & MISU, LEEDS \\
\hline Analysis of sea and cloud/fog water & Microgel abundance and size distribution, $\mathrm{pH}$ & ISB, MISU, BLOS, LEEDS \\
\hline
\end{tabular}


Table 3. Continued.

\begin{tabular}{|c|c|c|}
\hline \multicolumn{3}{|l|}{ Physical oceanography } \\
\hline \multicolumn{3}{|l|}{ At "Met Alley" } \\
\hline Turbulence mast & $\begin{array}{l}\text { Fast temperature and salinity, 3-D current velocities, turbulence, heat, salt and momentum } \\
\text { fluxes }\end{array}$ & GFI \\
\hline Microstructure profiler & Profiles of temperature, salinity, density, dissipation rate of turbulent kinetic energy & GFI \\
\hline Spectral radiometers & Spectral surface albedo and ice/snow transmittance & NPI \\
\hline \multicolumn{3}{|l|}{ At "Open Lead" } \\
\hline Automated bubble camera & Upper ocean bubble size spectra & FMI, LEEDS \\
\hline \multicolumn{3}{|l|}{ Sea water-ice chemistry } \\
\hline Sea surface microlayer analysis & $\begin{array}{l}\text { TOC, TN, nanoplankton enumeration by flow cytometry, dissolved amino acids, proteins, } \\
\text { DMS, DMSP, polysaccharides (dissolved, individual), microgels (abundance, properties), } \\
\text { pH }\end{array}$ & BLOS, ISB, MISU \\
\hline Subsurface seawater analysis & $\begin{array}{l}\text { Chlorophyll, POC and PON, TOC, TN, nanoplankton enumeration by flow cytometry, } \\
\text { dissolved amino acids, proteins, DMS, DMSP, polysaccharides (dissolved, acid, particu- } \\
\text { late, individual), proteomics, lectins, microgels (abundance, properties, size distribution), } \\
\text { pH }\end{array}$ & BLOS, ISB, MISU \\
\hline Sea ice and snow analysis & $\begin{array}{l}\text { Chlorophyll, TOC, TN, nanoplankton enumeration by flow cytometry, proteins, DMSP, } \\
\text { polysaccharides, microgel abundance }\end{array}$ & BLOS, ISB \\
\hline Ice algae analysis & Chlorophyll, POC, PON, TOC, TN, DMSP, polysaccharides, microgel abundance & BLOS, ISB \\
\hline
\end{tabular}

for volatile organic compounds (VOCs); note that the height of the upstream trajectories reaching the inlets is lower due to flow distortion. At the top of one mast, a cyclone operating at ambient relative humidity limited incoming particles to $D_{50}<1 \mu \mathrm{m}\left(\mathrm{PM}_{1}\right)$. The sample flow was set to $550 \mathrm{~L} \mathrm{~min}^{-1}$ through a $4 \mathrm{~cm}$ internal diameter pipe leading into the laboratory. An Andersen impactor (Andersen Inc., Atlanta, GA) at the top of the second mast excluded particles with $D_{50}$ $>10 \mu \mathrm{m}$ aerodynamic diameter $\left(\mathrm{EAD} ; \mathrm{PM}_{10}\right)$ at ambient relative humidity. The flow rate of $1100 \mathrm{~L} \mathrm{~min}^{-1}$ through a $9 \mathrm{~cm}$ diameter pipe into the laboratory gave a residence time in the pipe to the first outlet of $<1.4 \mathrm{~s}$. This flow was led to a pollution sensor consisting of a TSI-3025 UCPC connected to a control system similar to that described by Ogren and Heintzenberg (1990), which controlled all sampling systems sensitive to pollution. The inlets were designed to optimize the distance from the sea and from the ship's superstructure. Safe wind sectors relative to the ship and other criteria to minimize contamination were determined on previous expeditions, where it was determined that for winds $>2 \mathrm{~m} \mathrm{~s}^{-1}$ within $\pm 70^{\circ}$ from the bow, pollution from the ship did not reach these inlets (Leck et al., 1996). In ASCOS a third criterion was added; that the concentration of toluene remained below a variable threshold based on its long-term running mean.

Downstream of the sampling manifold, inside the aerosol container, a multitude of aerosol instruments and samplers were connected through isokinetic intakes. Parts of the manifold near the impactor intakes were controlled to maintain $50 \%$ relative humidity. The separate sampling line for VOCs was run from the mast to the third laboratory on the starboard side. All waste flows were directed to the pump house (to the right in Fig. 6) through dry-air gas meters and pumps, to a plenum and through a particle filter before the exhaust air was released back to the atmosphere. The second laboratory container housed instruments for chemical aerosol analysis and $\mathrm{SO}_{2}$ measurements. It also contained a clean room facility allowing preparation or change of specimens in air free from particles, $\mathrm{SO}_{2}$ and ammonia. The third container housed the PTR-TOFMS (Graus et al., 2010) organic trace gas instrument.

The container on the starboard side of the seventh deck (Fig. 6, yellow container to the left in the photo) housed the ship's weather station, and the (green) container to the right housed the sounding station. Both additionally housed electronics and computers for a multitude of other instruments on the seventh deck: the $60 \mathrm{GHz}$ scanning microwave radiometer on the starboard wing, and the M-AERI and the MuLID aerosol lidar on port side. The forward edge of the seventh deck also held several aerosol and fog/cloud water instruments, a radon instrument and a second additional (WeatherPak) weather station in the middle. Figure 7 shows Oden from the helicopter pad on the aft of the ship; here the radiosoundings were launched. Some other instruments on the seventh deck are also visible in this photo, for example the MuLID on the port wing, two celiometers, present weather and visibility sensors on the starboard side.

\subsection{Observations on the ice}

The second main platform was the ice floe itself; the aerial photograph of the ice floe (Fig. 4, taken on 26 August) has the locations of the instrumented sites indicated. This multiyear ice floe, covered by many melt ponds, was approximately $3 \mathrm{~km}$ by $6 \mathrm{~km}$ in size. Oden can be seen in the lower left corner of the ice floe, anchored at a local $\sim 120^{\circ}$ outside corner of the floe, which allowed mooring of the ship in four main orientations, as dictated by the wind direction. 
Table 4. Overview of availability of data from different instruments or groups of instruments from ASCOS at different times (3 August corresponds to DoY 215 and 7 September corresponds to DoY 251). Green fields indicate essentially complete data coverage, within the limitations of the deployment, and yellow fields indicate (somewhat arbitrarily) that some limitation in availability was present, either due to problems with the instrumentation, ship pollution, incomplete installations or reduced sampling for some other reason. White fields indicate that data are essentially missing; note that some very small fraction of data may still be present. For some data additional information is provided. "Ships maneuvering" indicates ship's operation (O: open water sampling, M: MIZ sampling, T: transit, D: drifting with ice, M: temporarily moving the ship while drifting). A fraction of the soundings were augmented by special sensors indicated by " $R$ " for radioactivity and "O" for ozone. For the ship's pollution system, the numbers indicate the fractional time without any pollution detected, in $\%$. A green field in the helicopter profile column indicates that at least one profile was made on that day; the number of flights is given in the green field. The surface samples are summarize in one row (I: sea ice, S: snow, A: ice algae).

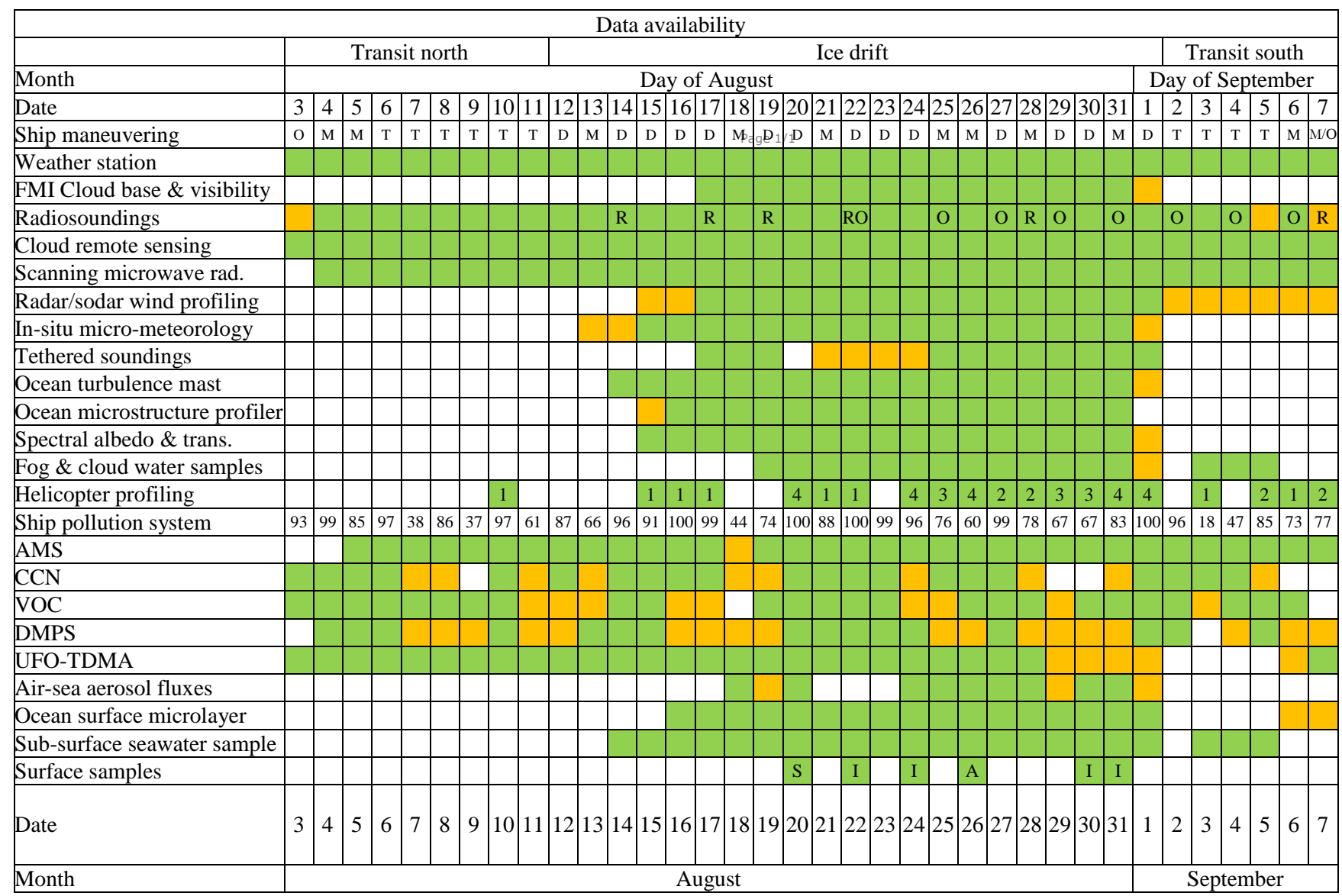

Boundary-layer meteorology and physical oceanography observations were deployed close to the ship (Fig. 8). Following the naming of SHEBA's "Met City" (Persson et al., 2002), this site was labeled "Met Alley"; the instruments were approximately located in a row away from the ship to minimize the range of wind directions in which flow distortion might contaminate the turbulence measurements. This part of the ice floe was $2-8 \mathrm{~m}$-thick, judging by numerous holes drilled to secure guy lines for the masts. Visible in the photo are the two masts $(15$ and $30 \mathrm{~m})$, the sodar and radiation measurement site, the tethered system and the oceanography site. The masts carried an array of sonic anemometers at six levels - five on the lower mast and one at the top of the $30 \mathrm{~m}$ mast - for measurements of turbulent heat and momen- tum fluxes; the sonic anemometers also provided mean wind speed profiles while two of these levels also held fast openpath gas analyzers for turbulent fluxes of water vapor and $\mathrm{CO}_{2}$. Thermistor-chain temperature profiles were installed over the $15 \mathrm{~m}$ mast and also into the ice, as well as many similar sensors for surface temperatures, sensors for absolute temperature and relative humidity, heat flux at the ice-snow interface and surface pressure. The sodar, measuring wind profiles and boundary-layer turbulence structure, and surface radiation sensors were located somewhat to the side since both of these are sensitive to disturbances.

The marine biology and chemistry site, the "Open Lead" site, was located about $3 \mathrm{~km}$ away (upper left corner of the floe in Fig. 4), relatively safe from contamination by the ship. 


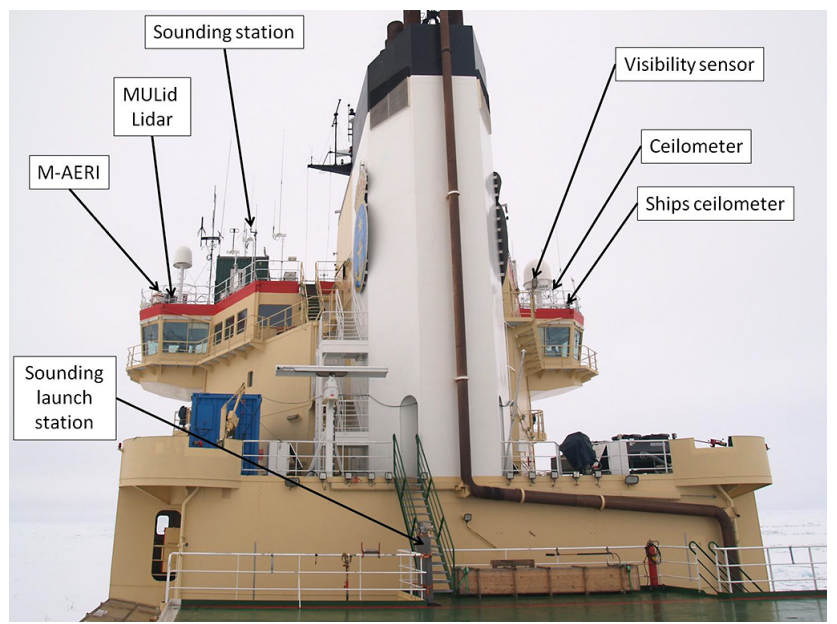

Fig. 7. Photograph of the installations on Oden as seen from the helicopter landing pad, which was also the sounding launch station; also seen are the location for several other instruments at the aft of the seventh deck.

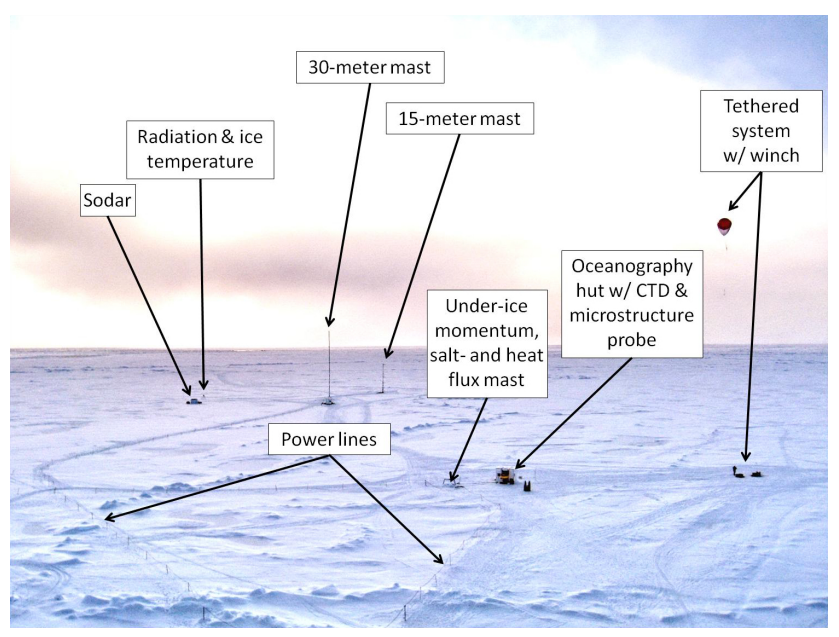

Fig. 8. Photograph of the "Met Alley" showing the location of the various sensor systems in vicinity of Oden.

Figure 9 shows the layout of this station, with the marine biology sampling platforms, the OOTI atmospheric chemistry instruments and the location for the underwater bubble camera. The inset in Fig. 9 shows the aerosol flux station located outside of the photo, behind the photographer, close to the ice edge. While the "Met Alley" was powered from the ship and the staff working here had the benefit of the resources of the ship nearby, the staff operating the "Open Lead" site was transported out every morning, carrying freshly charged batteries and food, and did not return to the icebreaker Oden until the late afternoon. Samples collected during the day were transported back and analyzed in the foredeck main lab (see Fig. 5). This site also had a small hut erected to provide shelter from the weather and protection from polar bears. As a

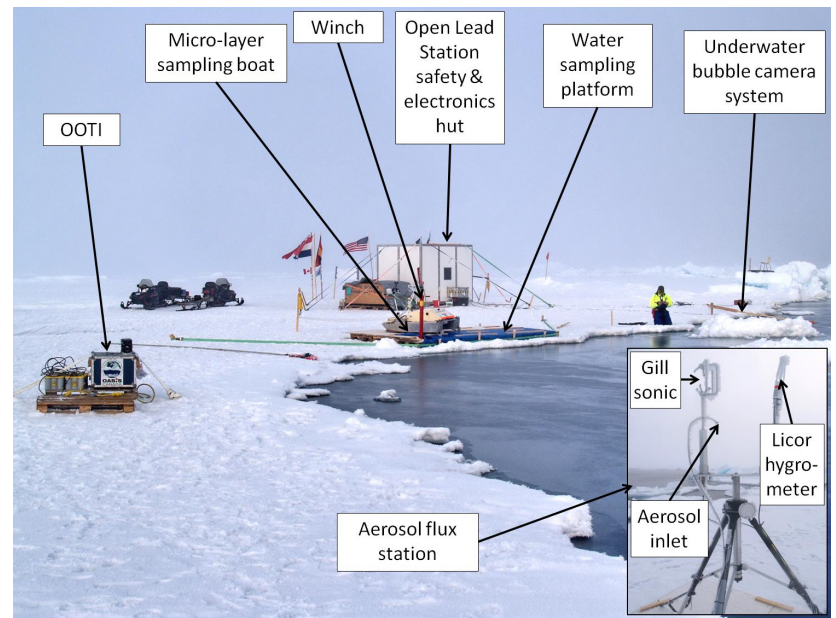

Fig. 9. Photograph of the "Open Lead" site showing the location of the various sensor systems away from Oden.

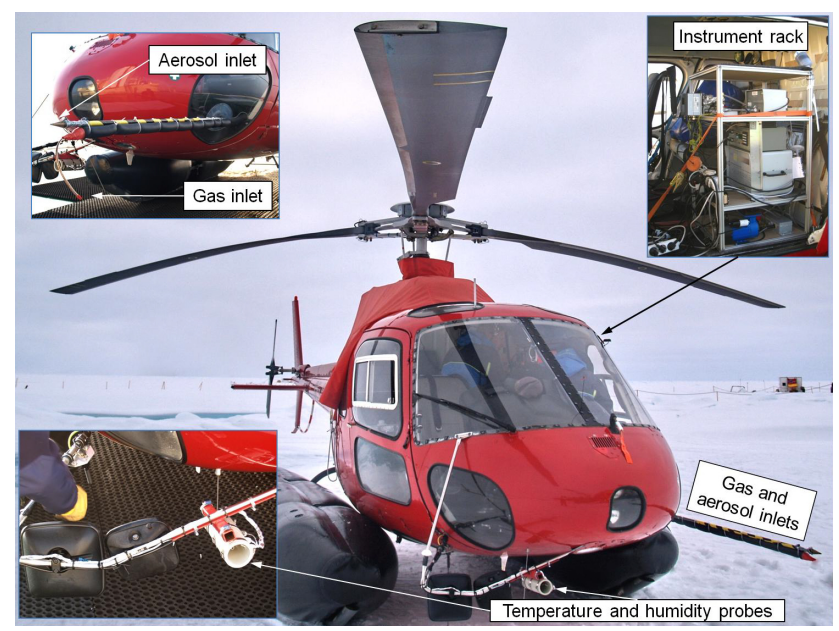

Fig. 10. Photograph of the helicopter that was used for vertical profiling, outlining some of the installations to sample meteorology, aerosol particles and trace gases.

curiosity, this site also held its own colony of seals that kept a close watch on the activity of the human guests.

\subsection{Airborne observations}

Figure 10 shows the helicopter, the third main ASCOS platform, used for profiling of aerosol particles and VOCs (Kupiszewski et al., 2013). On the port side of the helicopter, two inlets were installed: one for aerosol particles and one for trace gases. An instrument rack with pumps, aerosol counters and a gas-sampling flask system was installed at one of the passenger locations in the helicopter; gas samples were taken at different altitudes and were analyzed on board Oden. Ambient meteorological variables were also measured with probes on the starboard side. Figure 11 shows NASA's DC8 operating for the AMISA project during one of its flybys 


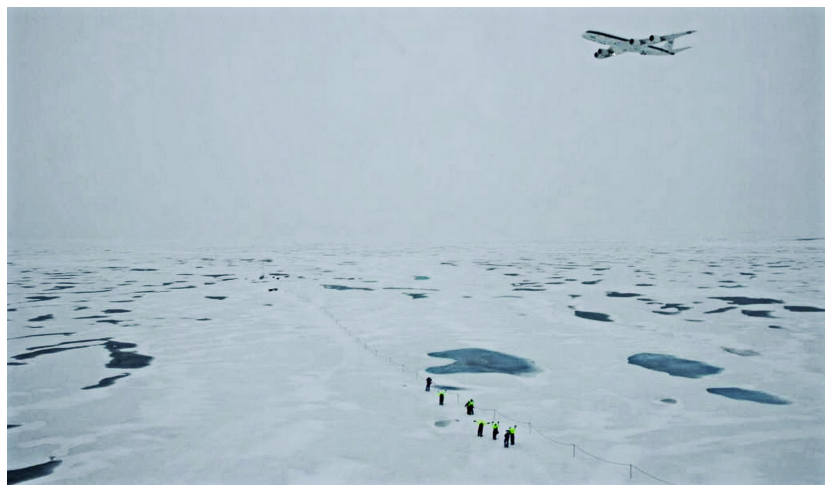

Fig. 11. Photograph of the NASA DC-8 research aircraft performing a flyby during its 12 August AMISA mission.

past ASCOS; AMISA conducted four such missions (Persson, 2010).

Work on the ice required special polar bear safety measures, while all movements on the ice, on foot, with snowmobiles or helicopters, were major contamination concerns. Early each day a polar bear reconnaissance was carried out by snowmobile, to scout for fresh bear tracks. Before this "secure sectors" were determined to minimize contamination of the observations on board by the snowmobile's exhausts. After an early morning visit by a polar bear at "Met Alley" during a dense fog episode, work on ice became suspended whenever the visibility became insufficient for polar bear guards on the ship's bridge to visually inspect the whole area. Operations at the "Open Lead" site were conducted with a dedicated armed guard on-site at all times.

\section{A selection of findings from ASCOS}

In this section we provide a selection of results from ASCOS, drawing from already published papers. The purpose is to provide a flavor of the accomplishments in ASCOS, but not to provide a comprehensive overview of the state of the science. Results presented here should also be considered in the context of the questions discussed in Sect. 2. This brief review is organized starting in the ocean and ending with the clouds, how they interact with the aerosols and the effects on the surface energy balance.

\subsection{Water-column physics and chemistry}

Sirevaag et al. (2011) describe high-resolution measurements of ocean stratification, turbulent mixing and exchange in the upper $500 \mathrm{~m}$ of the ocean and of shortwave radiation above and below the ice, during the transition from late melt season to the initial freeze-up. The ocean mixed layer was heated from the top, and heat was then redistributed downwards by turbulent mixing. Figure 12a shows time-depth cross sections of temperature and salinity. Note how the temperatures

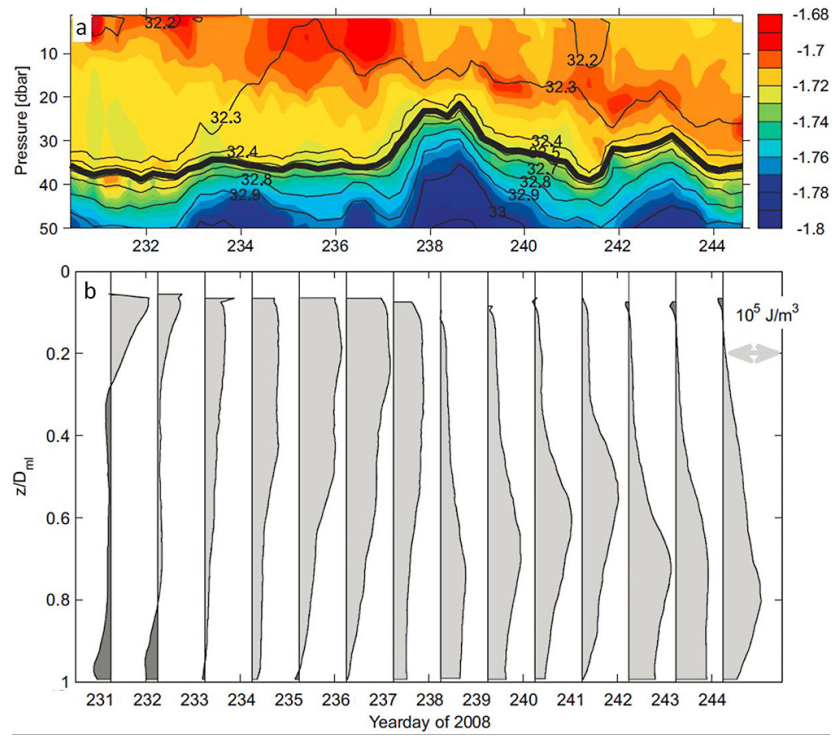

Fig. 12. In (a) contours of temperature $\left({ }^{\circ} \mathrm{C}\right.$, color shading) and salinity (psu, solid black), and in (b) daily difference profiles of heat content $\left(\mathrm{J} \mathrm{m}^{-3}\right)$ for subsequent $24 \mathrm{~h}$ averaged profiles relative to DoY 230.25; depth is normalized by the mixed layer depth for each profile. Light grey shading indicates heat gained from the first profile, and dark grey shading indicates heat lost from the first profile. The thick black line in (a) indicates the base of the mixed layer. Figure is adapted from Sirevaag et al. (2011).

were highest in the uppermost ocean, closest to the ice, until DoY 237 (23 August) and how this warmer layer thereafter propagated downward. This downward transfer of energy is also clear from Fig. 12b; each profile indicates the change in heat content from one day to the next compared to the same initial reference profile. There is a distinct shift from warming on top initially, ceasing with the change from DoY 237 to 238. After this, heat was then transported downward as the surface began to cool and eventually froze towards the end. Comparing the changing heat content of the mixed layer with the net fluxes into it, heat exchange through the ice accounted for on average $22 \%$ of changes in heat content, with a main contribution from transmittance of solar radiation through the ice; prior to DoY 238 net fluxes through the ice accounted for $45 \%$ of the heat change. Around DoY 238 a cold period was followed by snowfall that increased the surface reflectivity and added an insulating layer on top of the ice, whereafter very little heat was transferred through the ice.

Early work by Blanchard and Woodcock (1957) and Blanchard (1963) highlighted two distinct methods of airborne primary marine particle formation by bubble bursting at the water/air interface: so-called "film drops" and "jet drops". Breaking waves are known to be a major source of bubbles in the water column in the open ocean. In the Arctic summer, however, near-surface winds are generally weak (here $<\sim 6 \mathrm{~m} \mathrm{~s}^{-1} 70 \%$ of the time; Tjernström et al., 2012), and the open water fetch is small in leads in the pack ice. 
Hence, breaking waves are rare or absent, and until now it has been unclear whether bubbles even exist in the central Arctic Ocean environment (Leck et al., 2002). Norris et al. (2011) describe the first-ever reported observations of marine bubble spectra from the inner Arctic (Fig. 13). Substantial numbers of bubbles (up to $14 \mathrm{~cm}^{-3}$ ) with mean diameters $(D)$ between $30 \mu \mathrm{m}$ (the lower detection limit of the instrument) and $560 \mu \mathrm{m}$ were observed; the shape of the spectra implies that significant numbers of bubbles with $D<30 \mu \mathrm{m}$ are expected. The concentrations observed for $D<100 \mu \mathrm{m}$ are comparable with those found in the open ocean at lower latitudes under moderate wind speeds on the order of $10 \mathrm{~m} \mathrm{~s}^{-1}$, but at larger sizes the concentration decreases more rapidly with increasing size than do open ocean spectra; no bubbles larger than $560 \mu \mathrm{m}$ in diameter were observed. The total bubble number concentration shows two distinct dependencies on the local environmental conditions: concentrations were highest when the sampled ocean flow has a significant fraction of surface water open to the atmosphere. Concentrations were about an order of magnitude lower when the surface was completely frozen or when the flow was from under the large ice floe, thus isolated from open air for a period on the order of $10 \mathrm{~h}$ or more. With an open water surface, exposed to the atmosphere, the total number concentrations of bubbles also increased with increasing heat flux from the surface to the atmosphere. The observation of significant numbers of bubbles confirms the existence of a plausible mechanism to inject biogenic material from the water surface into the atmospheric surface layer, even in the absence of wind-driven wave breaking.

When melt was maximal and leads were most prevalent, we identified, characterized and quantified marine gels in seawater and, for the first time, also in the surface microlayer, ice, airborne aerosol and cloud water (Fig. 14, Orellana et al., 2011). These polymer gel networks reached high concentrations $\left(10^{6}-10^{9} \mathrm{~mL}^{-1}\right)$ with yields of assembly averaging $25 \%$, higher than published previously (Chin et al., 1998, Orellana and Verdugo, 2003). Polymer gels comprised as much as $50 \%$ of the total organic carbon, due to high concentrations in surface waters and the SML (Orellana et al., 2011). Gao et al. (2012) concluded that the enrichment of polysaccharides in the SML appeared to be a common feature, with enrichment factors of 7 for particulate and 12 for the DOM fraction. Gels assembled with faster kinetics than previously observed, probably due to the presence of hydrophobic moieties that enhance gel assembly (Orellana et al., 2007). During ASCOS, the diatoms Melosira arctica and Fragilariopsis cylindrus were the most abundant phytoplankton present in the water; they are known for surrounding their cells with polymer gels (e.g., Krembs et al., 2002), suggesting an important role in the production of biopolymers.

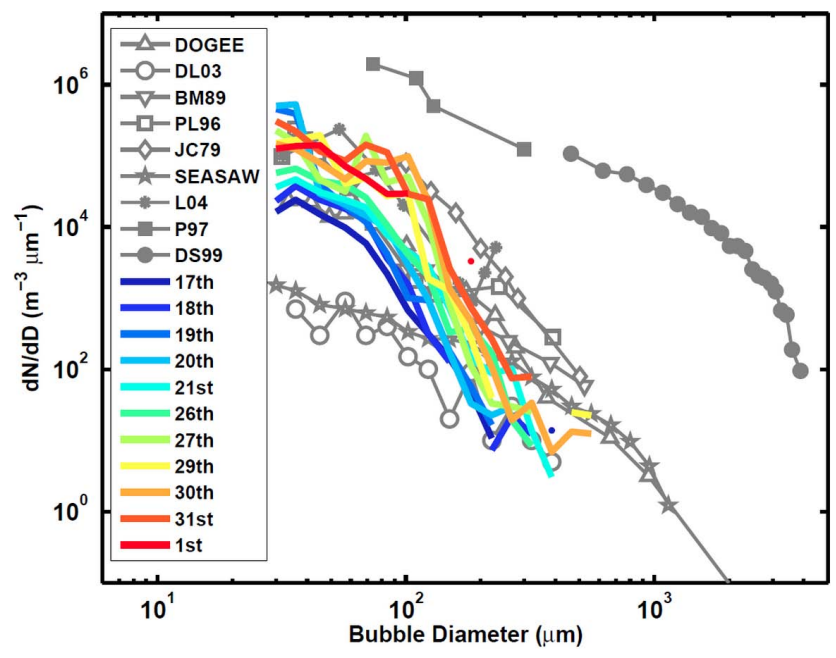

Fig. 13. Mean bubble spectra for several of the days during ASCOS (in color). A number of open ocean (grey open symbols) and surf zone spectra (grey filled symbols) are shown for comparison. The SEASAW $\left(U=8 \mathrm{~ms}^{-1}\right)$, DL03 $\left(U=5 \mathrm{~ms}^{-1}\right)$ and the ASCOS data were all measured at a depth of approximately $0.4 \mathrm{~m}$ using the same optical instrument. Acoustic measurement systems were utilized in the open ocean in DOGEE (averaged over a depth of 0-3 $\mathrm{m}, U=13 \mathrm{~ms}^{-1}$ ), BM89 (depth $0.25 \mathrm{~m}, U=12-15 \mathrm{~ms}^{-1}$ ), PL98 (depth $0.5 \mathrm{~m}, U=12-14 \mathrm{~ms}^{-1}$ ) and JC79 (depth $0.7 \mathrm{~m}, U=11-$ $13 \mathrm{~ms}^{-1}$ ), and in the surf zone (L04, P97 and DS99). Figure is adapted from Norris et al. (2011); see discussions therein and in Brooks et al. (2009).

\subsection{Aerosols in air and in cloud droplets}

The confirmed existence of bubbles in the water column, even when waves are not breaking, constitutes a potential source of primary particulate matter from the open water leads. With the suggestion from the previous expeditions that an unknown fraction of airborne and in-cloud aerosol were polymer gels originating either in local open water leads or from a distant source, such as the MIZ, an attempt was made to quantify the net contribution of the local lead aerosol flux to the observed aerosol concentrations. Direct eddy covariance observations of the net aerosol flux into the atmosphere were performed at the ice edge near the "Open Lead" site (Held et al., 2011a); the results compared well with independent estimates obtained from aerosol concentration gradients very close to the water surface (Held et al., 2011b).

Although fluxes were directed both upward and downward, dividing the fetch into sectors for different surface characteristics, net upward fluxes occurred for wind directions where the fetch was dominated by open water, while sectors dominated by the ice floe had a downward net flux (Fig. 15a, c). Open-water sectors also contributed to a larger fractional time with upward fluxes (Fig. 15b). However, the direct eddy covariance particle number fluxes in Held et al. $(2011 \mathrm{a}, \mathrm{b})$ indicated that the direct contribution of the 

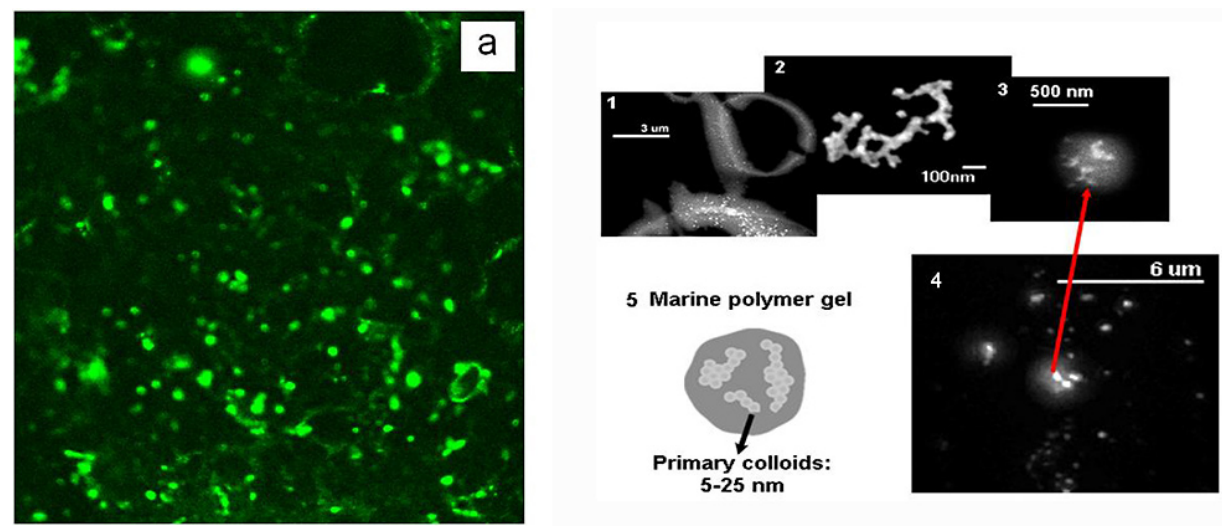

Fig. 14. (a) Marine polymer gels in cloud water immunostained with a specific antibody developed towards polymeric material collected in surface microlayer and subsurface waters. (b) Structure of polymer gels showing the following: (b1) low water-soluble organic particles in the surface microlayer present large quantities of colloidal-size nanogels $(<1 \mu \mathrm{m}$ diameter), which assembled into larger than $3 \mu \mathrm{m}$ diameter microgels; (b2) colloidal-size nanogels measured by FESEM microscopy tend to present fractal structures in sizes generally under $200 \mathrm{~nm}$ diameter and always smaller than $1 \mu \mathrm{m}$ in both surface microlayer and cloud samples; (b3 and b4) the gels in the cloud samples present average sizes between 200 and $700 \mathrm{~nm}$, with colloidal-size nanogels partitioned inside of the polymer gels; (b5) the schematic illustration shows that colloidal-size nanogels tend to present a fractal structure of the larger microgels. Figure is adapted from Orellana et al. (2011).

open lead net particle emissions could only explain a few percent of the observed total particle number variability measured on board the ship. Unfortunately, no information about the size of the emitted particles was available from the direct flux measurements, so that a direct comparison with different particle modes cannot be performed. Note also that expecting correspondence between local aerosol surface flux and variability assumes horizontal homogeneity over some distance.

At the same time, results for the first time confirm that the polymer gels in airborne aerosol and in cloud water originated in the ocean (Orellana et al., 2011), and support the hypothesis of a link between cloud formation and marine gels in the ocean SML (Leck and Bigg, 1999, 2005b, 2010; Leck et al., 2002; Bigg and Leck, 2008). This unique result was achieved through development of a highly specific antibody for seawater biopolymers and immunostaining applied on samples collected in cloud, fog, and airborne aerosol (Orellana et al., 2011). The results show unambiguously that the same polymetric gel material, the Melosira arctica community, was present in the surface water, in the air and in fog and cloud water (Fig. 14a).

Kupiszewski et al. (2013) summarized the results from aerosol profiling using the helicopter for a number of episodes during ASCOS. One episode involves an elevated plume aloft with high concentrations of ackumulation mode particles that they suggest may have been caused by Siberian forest fires and subsequent long-range transport. They conclude that these long-range transported plumes are unlikely to be mixed down to the planetary boundary layer (PBL). One other case involves very low boundary-layer aerosol concentrations followed by a new particle formation (nucleation) event; however, the observed concentrations of poten- tial precursor gases would normally preclude homogeneous nucleation.

Employing state-of-the-art aerosol formation modeling, Karl et al. (2013) used data from ASCOS to model the observed sudden formation of new particles simultaneously in several distinct size ranges below $50 \mathrm{~nm}$ in diameter. The authors suggested a novel route to formation of new atmospheric nanoparticles, involving biogenic granular colloidal nanogels from evaporating clouds droplets, hence hypothesizing that cloud processing may explain the inconsistency between the observed total particle number variability measured on board the ship and the measured surface flux.

Martin et al. (2011) performed a CCN closure study using data from ASCOS and found that for large supersaturations $(0.41$ and $0.73 \%)$ ) closure could not be achieved; calculated $\mathrm{CCN}$ number concentrations were higher than the measured. This might be caused by a relatively larger non-watersoluble organic mass fraction for particles in the subaccumulation or smaller size ranges. At lower supersaturation $(0.20$, 0.15 and $0.10 \%$ ) closure was achieved, and the best closure was achieved when the organic fraction of the aerosol was treated as nearly non-water-soluble. Based on the study by Orellana (2011), the polymer gels (non-water-soluble) have been shown to consist of hydrophilic and hydrophobic segments in agreement with their chemical behavior modeled by Xin et al. (2013). The interaction of the hydrophilic and hydrophobic entities on the behavior of the polysaccharide structures during the cloud droplet activation strongly suggests a dichotomous behavior of polymer gels (Ovadnevaite et al., 2011). Only partial wetting character is shown below $100 \% \mathrm{RH}$, and thus only weak hygroscopic growth. At the same time a high CCN activation efficiency is found, which is promoted by the hydrophilicity or surface-active properties 

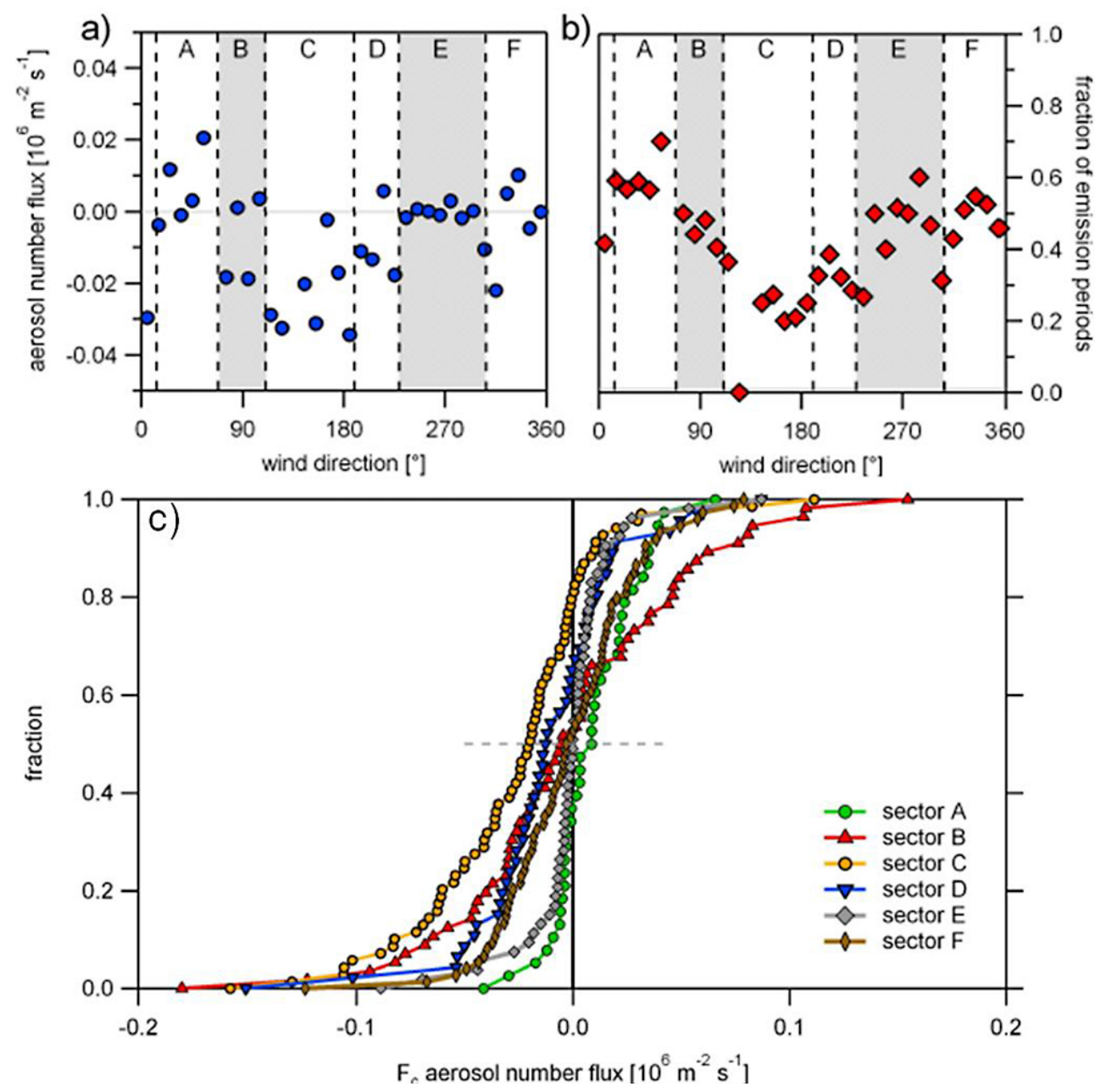

Fig. 15. Bin-averaged, with six different sectors (A-F) indicated, (a) median aerosol number fluxes over $10^{\circ}$ wind direction bins and (b) time fraction of emission episodes averaged overlapping $30^{\circ}$ wind bins plotted every $10^{\circ}$, with (c) the cumulative distribution of aerosol number fluxes for the six different sectors. The sectors are determined according to upwind surface characteristics, where A and $\mathrm{F}$ are shorter and longer open water fetch, C and D are rougher and smoother ice surfaces and B and E (grey shaded) are a mixture of open water and ice. Figure is from Held et al. (2011).

of the gels. The chemical and physical behavior of the polymer gels is in good agreement with the CCN closure experiments by Martin et al. (2011), which indicate that the organics present in the particles are non-water-soluble. Nevertheless, the picture concerning the role and significance of the marine gels in aerosol-cloud interactions in the high Arctic is still incomplete and deserves attention for future investigations.

Addressing the possibility of advection of aerosols or aerosol precursors from more distant sources, such as the MIZ, Heintzenberg and Leck (2012) used statistics of modal aerosol number concentrations from all four Oden-based expeditions, and discussed selective "filter" effects from scavenging of aerosol particles in fog and low clouds in lowlevel air entering the pack ice from the MIZ in summer. This sink region in the MIZ for particles in the sub-micrometer size range (Nilsson and Leck, 2002), within <2-3 days of travel time from the ice edge, was confirmed and the statistics also indicated sub-micrometer particle sources in the inner Arctic being most pronounced in the smallest particles sizes $(<26 \mathrm{~nm}$ in diameter).

Chang et al. (2011) analyzed results from aerosol mass spectrometer measurements and concluded that nonrefractory (chemically and physically unstable at high temperatures) submicron aerosol particles were composed of approximately equal amounts of organic and sulfate components, influenced by both marine biogenic and continental sources (33\% and $36 \%$ of the sampled ambient aerosol mass, respectively). There also appeared to be a presence of an almost purely organic aerosol (31\% of the sampled ambient aerosol mass). As Chang et al. (2011) were unable to detect marine gels, with their refractory properties reported in 
Orellana et al. (2011) and in Leck et al. (2013), its source can also be presented with alternative explanations. Hence, while results in the Chang et al. (2011) paper indicate a continental influence, they could not rule out sources either in local open water leads or from a distant source at the MIZ emitting primary oxygenated organic aerosols (Leck and Bigg, 2005).

Shupe et al. (2013) analyzed the vertical atmospheric coupling between the surface and clouds, suggesting the importance of long-range advection as a source of aerosol for the clouds. Using vertical profiles of derived turbulent dissipation rate and potential temperature, their results indicate that mixed-phase stratocumulus clouds observed during ASCOS were frequently decoupled from the surface; during an analyzed week-long stratocumulus period this decoupling occurred approximately $75 \%$ of the time. Vertical mixing under these cloud conditions is primarily driven by radiative cooling in the cloud layer, resulting in buoyancy-forced turbulent eddies. Coupling of the cloud-driven mixed layer with the near-surface boundary layer is largely determined by the proximity of the cloud to the surface, with surface fluxes having little effect on this coupling state.

Important differences were observed in surface-coupled versus decoupled cloudy air masses. Under surface-coupled conditions the cloud-driven mixed layer had a potential temperature similar to that of the ice- and ocean-covered surface, near the melting point of sea ice. However, for decoupled periods, the cloud-driven mixed layer was generally warmer than the underlying surface, suggesting that these air masses had not equilibrated with the surface conditions via cloudsurface coupling along the upwind trajectories. Helicoptermeasured concentrations of aerosols larger than $300 \mathrm{~nm}$ also tended to show a similar vertical structure. In cloud-surface coupled cases, concentration was approximately constant from cloud base down to the surface. However, in decoupled cases, the aerosol concentration was higher within the cloud-driven mixed layer, and lower at some height below this mixed layer. Moreover, in the few cases when the helicopter was able to penetrate through cloud top, an increase in the aerosol concentration was observed above the cloud top. Together these results suggest that the aerosols important for the stratocumulus cloud formation advected into the region at, or above, the cloud level and may have been replenished via cloud top entrainment processes. Hence if the cloud layer remains decoupled from the surface for extended periods of time, it follows that local surface sources of aerosols and moisture at the surface do not impact the cloud; this does not mean that surface sources upstream of the measurement site, under better mixed conditions, may not have impacted cloud properties.

\subsection{Meteorology and the surface energy balance}

An overview of the meteorological conditions during the expedition can be found in Tjernström et al. (2012). The summer Arctic boundary layer during ASCOS was typically well mixed and shallow, capped by a temperature inversion. The inversion may at times be strong, such as when there is substantial advection of warmer air from lower latitudes. The vertical structure was often characterized by a generally shallow wind-shear-driven surface PBL topped by a cloudy layer, generating turbulence by buoyancy from longwave radiative cloud-top cooling. Depending on the relative strength of the two mixing processes, and the altitude to the cloud (Shupe et al., 2013), this system sometimes appeared as one single well-mixed layer, with depths usually below $\sim 300 \mathrm{~m}$, and sometimes as two separated but turbulent layers that together were quite deep, up to $\sim 1 \mathrm{~km}$ or more. Specific humidity often increased with height over the PBL-capping inversion. This is a condition that rarely occurs elsewhere but is frequent in the Arctic (Sedlar et al., 2012) and implies that entrainment across the inversion is a moisture source for the boundary layer rather than a sink. Sedlar et al. (2012) also showed how cloud tops often penetrated significant distances into, rather than being capped by, the capping inversion. Boundary layer relative humidity was consistently close to $100 \%$, with respect to water when the temperature was close to zero and to ice when below, in fact often $>100 \%$ with respect to ice.

Low clouds dominated generally cloudy conditions with cloud bases most often below $100 \mathrm{~m}$. Cloud thickness rarely exceeded $1 \mathrm{~km}$, except for in frontal clouds associated with weather systems. Visibility was bimodal: $<1 \mathrm{~km}$ in fog and $>20 \mathrm{~km}$ even below very low clouds. Sedlar et al. (2011) analyzed the surface energy balance and the effect by lowlevel clouds, the so-called surface radiative cloud forcing (Fig. 16a), during the transition from melt to freeze conditions. During the first portion of the ice drift, the net residual energy flux into the surface from above and below was positive (Fig. 16b). Since we measured all components of this flux, this means that surplus energy was available for melting of the surface. The magnitude of the residual was almost as large as the net shortwave radiation component and is significant. Sedlar et al. (2011) also found that after a brief cold period and a passing weather system depositing new snow (see above; also see Sirevaag et al., 2011; Tjernström et al., 2012), the surface albedo increased substantially. After this, the system could not revert to melting again.

Figure 16a shows how the surface radiative forcing by the low clouds prevented further freezing until about a week after this first cold episode. This late in summer, the surfaceradiative forcing by the clouds, here from a semi-persistent low-level stratocumulus cloud layer, is dominated by longwave radiation, and it is not until this cloud layer becomes tenuous and eventually disappears around DoY 244 (31 August) that the actual freeze-up is realized. This is also explained by the energy fluxes during the different periods (Fig. 16b). During the first period through DoY 233 (16 August) there is a positive energy residual, and thus the surface is melting. During the colder period that follows, the net longwave radiation on average becomes negative and the 

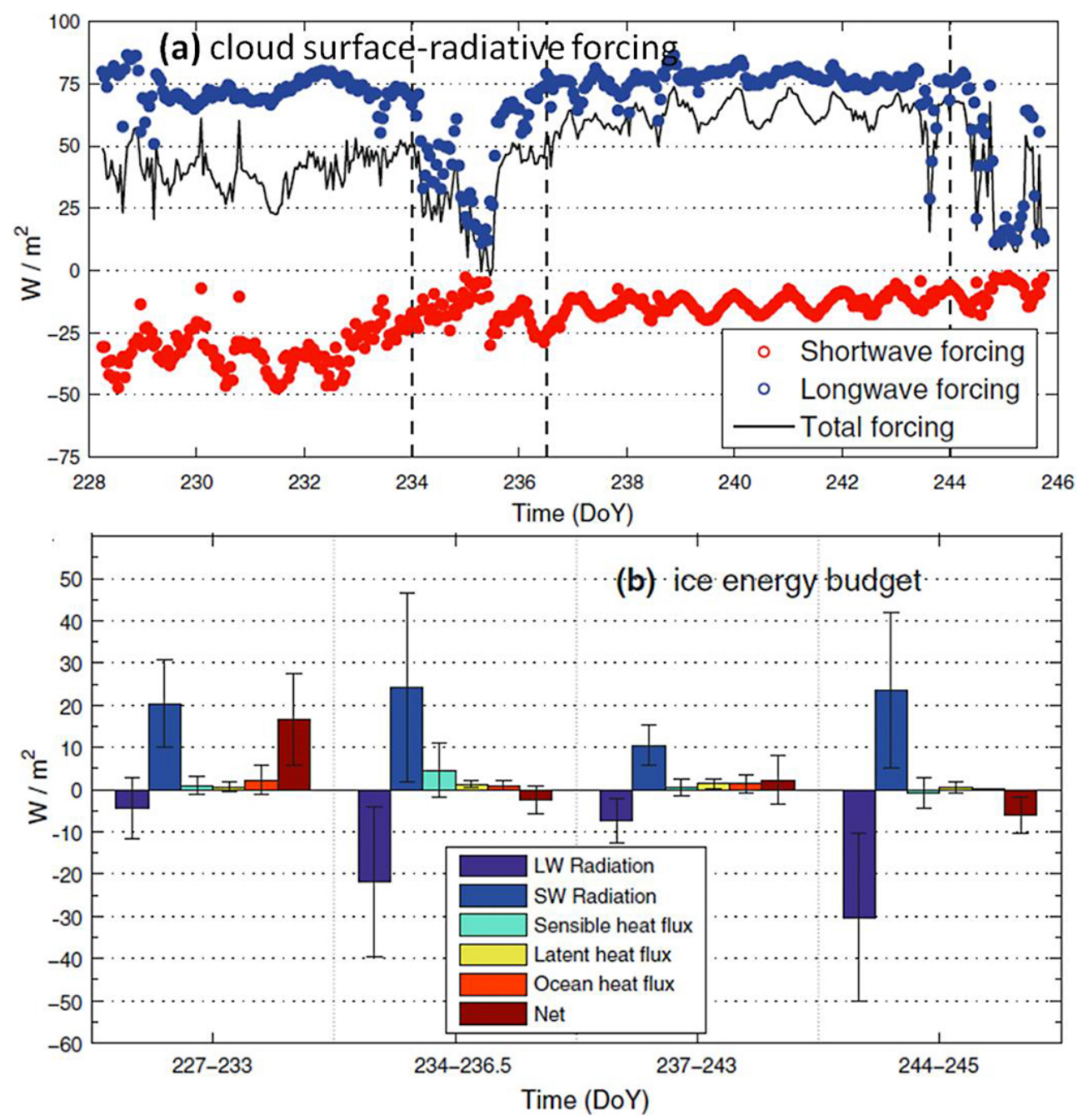

Fig. 16. (a) shortwave (red circles), longwave (blue circles) and total cloud radiative forcing (black line), all in $\mathrm{W} \mathrm{m}^{-2}$, and in (b) the mean components of the energy budget terms for the sea ice in $\mathrm{W} \mathrm{m}^{-2}$ calculated over the four main time regimes identified by dashed black line in (a). Positive fluxes represents a warming at the surface and negative flux a cooling, except for sensible and latent heat fluxes, which are defined traditionally where positive is cooling. The ice budget includes ocean heat flux and transmission of solar radiation but excludes conduction. Black variability bars represent \pm 1 standard deviation of the mean fluxes for each respective regime, and the net flux is calculated as the residual. Figure is adapted from Sedlar et al. (2011).

residual energy essentially disappears. As the first short cold period ends, however, the surface albedo has increased and the solar zenith angle increased so that the residual energy remains near zero. Then as the clouds (and with them the longwave surface cloud forcing) vanish, the freezing starts, as manifested by the negative residual energy flux, which is also significant.

\subsection{Aerosol-cloud interaction and the surface energy balance}

The actual freezing thus starts when the low-level clouds, and their longwave surface forcing, are reduced; during ASCOS this happens in an interesting period when the cloud layer becomes tenuous - optically thin. Such clouds are be- lieved to be an important part of the Arctic climate system but are difficult to observe, particularly from satellites. Surfacebased radar provide the best measurements, and show the clouds to occur frequently in the Arctic winter. However, their frequency of occurrence in the central Arctic Ocean during summer is not known. Mauritsen et al. (2011) used a radiative transfer model to link the short- and longwave surface cloud forcing to the number of cloud droplets and compared these calculations to the observed surface cloud forcing and observations of $\mathrm{CCN}$ as a proxy for cloud droplet concentration (Fig. 17). The results reveal two regimes: one regime with $\mathrm{CCN}$ concentrations $<\sim 10 \mathrm{~cm}^{-3}$, in which an increase in $\mathrm{CCN}$ concentration would lead to a large relative surface warming, primarily due to the longwave radiation 


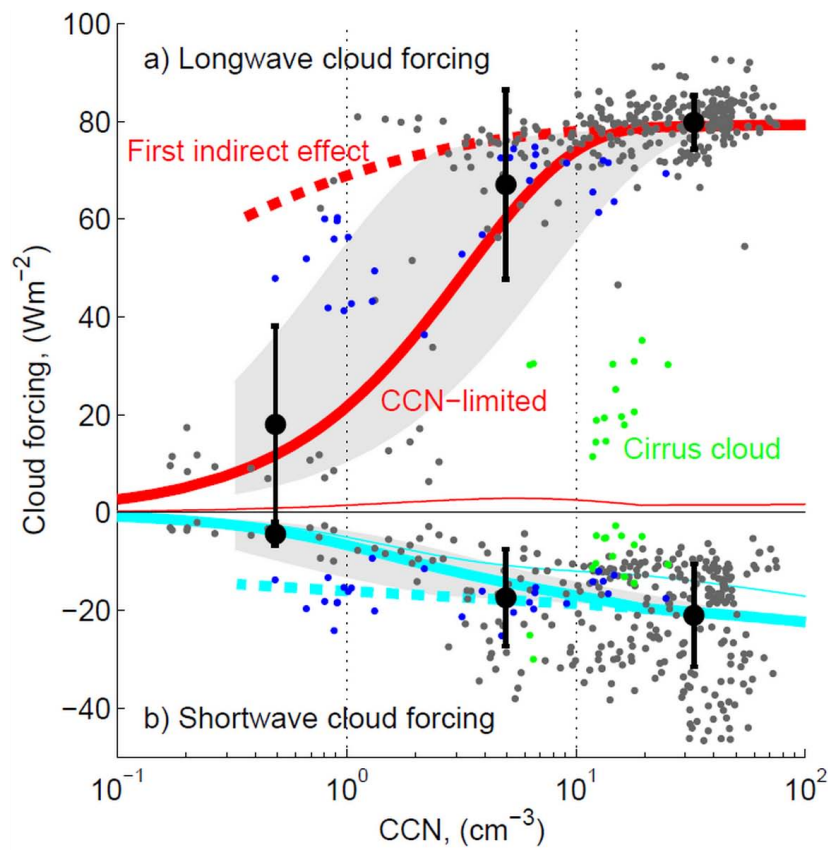

Fig. 17. Surface (a) longwave and (b) shortwave cloud radiative forcing as a function of $\mathrm{CCN}$ number concentration. $\mathrm{CCN}$ measurements were made at a supersaturation of $0.2 \%$. Dots are hourly observations; lines are idealized radiative transfer calculations described in the text. Dashed lines represent the first aerosol indirect effect only. Solid thick lines correspond to cloud liquid content being limited by effective radius $R_{\mathrm{e}}<15 \mu \mathrm{m}$. The grey shaded areas show the sensitivity to critical $R_{\mathrm{e}}$ values between 10 and $30 \mu \mathrm{m}$. Thin solid lines are the long- and shortwave cloud forcing at the top of the atmosphere. Large black dots are bin-averaged values for each decade of CCN concentration, and bars indicate the standard deviation from the decade mean. Green markers are related to a single case with mid-tropospheric ice clouds that are radiatively very different from low-level stratus cloud, and the $\mathrm{CCN}$ concentration measured near the surface is not relevant for these clouds. Blue markers are cases for which the $\mathrm{CCN}$ measurement is particularly sensitive to the choice of supersaturation, due to a steep cumulative size distribution near the critical size for activation at the supersaturation used. Figure is from Mauritsen et al. (2011).

effects, and a second regime for higher $\mathrm{CCN}$ concentrations $\left(>\sim 10 \mathrm{~cm}^{-3}\right)$, in which an increase in concentrations would lead to a relative surface cooling, through the so-called Twomey effect (Twomey, 1977); the relative warming in the former is much larger than the relative cooling in the latter.

Mauritsen et al. (2011) hypothesize that the cause of the tenuous cloud regime is that when the CCN concentrations fall below some critical value, droplets grow large and rapidly sediment out. This contributes both to keeping the $\mathrm{CCN}$ concentrations low, by the removal of the $\mathrm{CCN}$, and to removing cloud water, thus keeping the clouds optically thin. This process was emulated in the radiative transfer modeling by removing cloud liquid whenever the cloud droplet effective radius, $R_{e}$, reached a threshold value of $\sim 15 \mu \mathrm{m}$, in
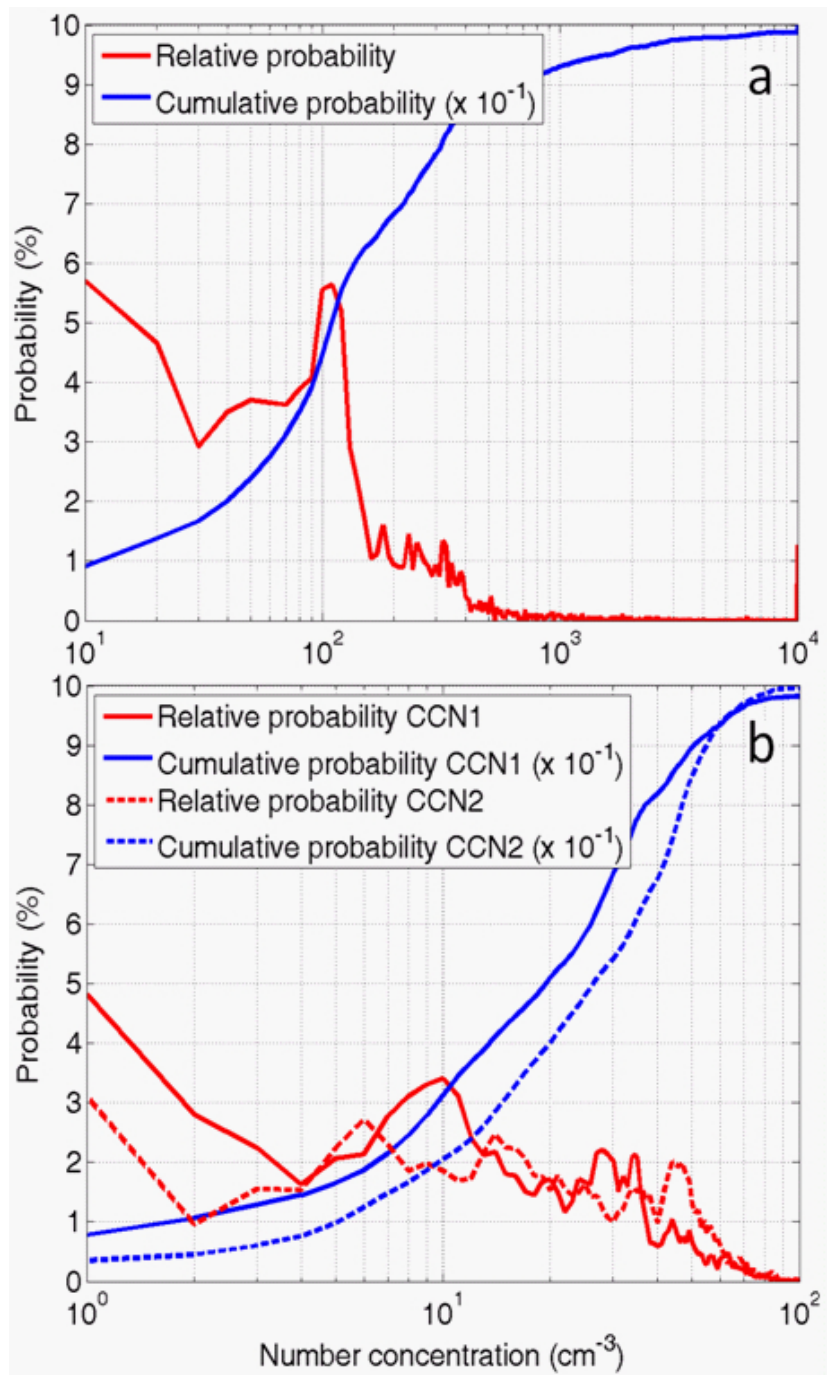

Fig. 18. Relative (red) and cumulative (blue) probability (\%) of (a) all aerosols sampled with a differential mobility particle sizer system and (b) CCN from two instruments (solid and dashed) both set at $0.2 \%$ supersaturation, for the entire expedition.

order to emulate the effect of drizzle, effectively the second indirect effect (Albrecht, 1989). The resulting modeled cloud forcing as a function of $\mathrm{CCN}$ agreed well with observed values, whereas the Twomey effect alone was insufficient to explain the observations. An analysis of corresponding CCN data from the previous three Oden-based expeditions (Mauritsen et al., 2011) indicates that this tenuous cloud regime could be quite frequent during the Arctic summer, occurring about $30 \%$ of the time. Following this Birch et al. (2012) used the ASCOS observations to show that the surface radiation budget and near-surface temperatures in the UK Unified Model are significantly improved during this tenuous cloud regime when run with observed $\mathrm{CCN}$ concentrations.

This tenuous cloud regime could be quite common, given the low concentrations of aerosol particles that prevail in 
the summer Arctic. Figure 18 illustrates the low concentrations of both total aerosol and CCN. The probability for the total aerosol concentration (Fig. 18a) peaked at $100 \mathrm{~cm}^{-3}$ and $0.1 \mathrm{~cm}^{-3}$, and the probability for concentrations above $1000 \mathrm{~cm}^{-3}$ is virtually zero; the total concentration was $<100 \mathrm{~cm}^{-3}$ about $45 \%$ of the time and $<200 \mathrm{~cm}^{-3}$ about $70 \%$ of the time. The result for CCN (Fig. 18b) was similar, but the peak at very small concentrations $\left(\sim 1 \mathrm{~cm}^{-3}\right)$ is more pronounced. The CCN concentrations were $<10 \mathrm{~cm}^{-3} \sim 20$ $30 \%$ of the time and $<20 \mathrm{~cm}^{-3} \sim 40-50 \%$ of the time.

\section{Discussion and conclusions}

This paper discusses the scientific rationale, planning, implementation of, and some important results from, the Arctic Summer Cloud Ocean Study (ASCOS), the largest atmospheric central Arctic Ocean experiment conducted during the International Polar Year 2007-2008. During 40 days in August and the beginning of September (2 August to 9 September), 33 scientists with backgrounds in large-scale and boundary-layer meteorology, cloud physics, atmospheric gaseous and particulate phase chemistry and physics, marine chemistry and biology, and physical oceanography joined 31 crew and logistics staff on the Swedish icebreaker Oden for an expedition to the central Arctic Ocean to study the formation and life cycle of Arctic low-level clouds.

As is illustrated by the examples in the previous section, ASCOS was successful in providing new and unique observations that can improve the understanding of summer central Arctic Ocean low-level clouds, their formation, and their effects on the boundary-layer and surface energy balance. Many of the findings are unique, such as evidence of primary marine biogenic particles from the open lead in low-level air and cloud water samples, and the presence of bubbles in the upper ocean, which provide a mechanism for injecting these particles into the atmosphere. Although we occasionally observed long-range transported biomass burning or pollution plumes in helicopter profiles, these always occurred in the free troposphere at altitudes well above the boundary layer top, and we did not find evidence of any light-absorbing (at $550 \mathrm{~nm}$ ) carbon particles, commonly referred to as "black carbon" or "soot", near the surface. All components of the energy fluxes into the surface and through the ice were observed through the seasonal transition from sea-ice melt to freeze-up, while cloud properties were simultaneously monitored. Optically thin low-level stratocumulus clouds were present roughly $30 \%$ of the time during ASCOS. The warming impact of these clouds on the surface during late summer, and the effects they have on the onset of surface freeze-up, was demonstrated in detail. Thus, the aim to observe, in detail, conditions from the late summer melt season, the biologically most active period, into the start of the freeze-up was realized, and a wealth of data were taken during both the end of the melt season and the initial freeze. Quality-controlled data from ASCOS can now be downloaded from the ASCOS web page (http://bolin.su.se/data/) and used by the scientific community for hypothesis testing, model development and evaluation, development of remote-sensing algorithms, and much more.

Scientific questions of course still remain and new ones have appeared. As illustrated in Fig. 2, several hypothesized sources and processes may contribute to the aerosol population over the central Arctic Ocean, and thus to the occurrence of CCN and IN necessary for cloud formation and governing the cloud optical properties. The question of whether the source of aerosol particles for summer central Arctic clouds is local or whether aerosols are imported by long-range advection from the MIZ, or south thereof, is critical for understanding Arctic climate and climate change processes. Since $\mathrm{CCN}$ number concentrations in the central Arctic are low, small changes can substantially alter the clouds and their impacts on the surface. Moreover, sources that in other regions would be considered marginally important might be important for the Arctic aerosol.

While ASCOS provided a wealth of new observations on this system, the ultimate partitioning of aerosol particles among sources remains elusive. Here, it is worthwhile to consider the complementary, and sometimes contradictory, findings in more depth. The fact that we determined that near-surface airborne aerosols, as well as low-level cloud and fog droplets, contained the same type of organic material as found in the open-lead SML (Orellana et al., 2011) supports the hypothesis of a local or regional aerosol source within the pack ice. The presence of bubbles in the water column (Norris et al., 2011) provides a plausible mechanism for getting SML material airborne. However, direct measurements of aerosol number concentration fluxes (Held et al., 2011a) could not explain the simultaneously observed near-surface airborne aerosol concentration variability. Even though the ASCOS open lead was a net source of aerosol particles, the snow surface on the surrounding ice was a net sink. Considering the regional ice fraction, this suggests that the surface as a whole may have been a net sink of aerosols in terms of total number concentration. However, statistical analysis of aerosol observation from four Arctic experiments on Oden, including ASCOS (Heintzenberg and Leck, 2012), suggests particle sources in the innermost Arctic. There appears to be an inconsistency when comparing direct observations of local aerosol flux to statistical interpretations of aerosol properties and concentrations; this remains an important question to answer.

The primary organic material from the ocean surface found in atmospheric aerosol and cloud droplets may also have come from the same biological processes but occurring upwind of Oden, near the MIZ and the open ocean beyond. If mixed through the deeper atmospheric mixed layer over the open water, these aerosols could be advected in over the central Arctic on top of the shallow local boundary layer, typically only a couple hundred meters deep (Tjernström, 
2005, 2007; Tjernström et al., 2012), while efficient scavenging processes associated with low clouds and fog near the MIZ (Nilsson and Leck, 2002; Heintzenberg and Leck, 2012) may explain the very low near-surface aerosol concentrations. Aerosol particles or their precursors in the upper layer could potentially be advected over long distances and later be entrained into the local boundary layer through the cloud top by cloud-induced mixing (e.g., Shupe et al 2013). The fact that specific humidity commonly increases over the boundary layer inversion, which rarely happens elsewhere, supports this hypothesis; entrainment of this humidity also acts to moisten the boundary layer (Tjernström, 2005, 2007; Tjernström et al., 2012), manifested in the very high relative humidity near the surface (Tjernström et al., 2012). Lundén et al. (2010) used a mesoscale model and showed how longrange advection could explain observed DMS maxima in the lower free troposphere from AOE-2001. ASCOS helicopter profiles flown in brief clear conditions during ASCOS (Kupiszewski et al., 2013; Shupe et al., 2013), and also during AOE-2001, sometimes feature a layer of substantially increased particle concentrations in the free troposphere immediately above the boundary layer and cloud top. However, this aerosol layer above the cloud top could also be due to evaporation of detrained cloud droplets. Sedlar and Tjernström (2009) and Sedlar et al. (2012) showed that cloud tops often penetrate a substantial distance up into the warmer air in the inversion. Enhanced aerosol concentrations are, however, also found within the cloud-induced mixed layer when this mixed layer is decoupled from the surface (Shupe et al., 2013), suggesting that the aerosol source was from above cloud top.

A related complication is the fact that the low-level mixedphase clouds that we observed during ASCOS were often decoupled from the surface (e.g., Tjernström et al., 2012; Shupe et al., 2013). Thus, even given a substantial local aerosol source over the ice-covered Arctic Ocean, these particles would not be available for cloud formation in the absence of convection. Low-level stratocumulus clouds during ASCOS quasi-constantly precipitated ice particles (Shupe et al., 2013), indicating that IN must have been present at cloud level, while the observations near the surface indicated none. This observation is consistent with IN entraining at cloud top and/or advecting with the cloudy air mass but may also be related to threshold problems with the instrument, or to the measurement technique itself; formation of ice particles may follow several different paths while the instrument only mimics some of these. During two earlier Arctic Oden cruises, the median concentrations of IN on board the ship ranged from 1 to $18 \mathrm{~m}^{-3}$ (Bigg and Leck, 2001), suggesting that some IN does occur in near-surface air in the central Arctic.

Moreover, locally generated aerosol not forming IN near the surface may be a result of the physicochemical behavior of the gelatinous polymer network, dependent on temperature, UV light and time of transport once airborne. Simply put, particles that were not good IN in near-surface air might, with time, change character and once inside a cloud droplet become IN. We also found indications of a linkage between turbulence mixing in low-level stratocumulus and formation of either liquid droplets or ice crystals (Shupe et al., 2013) that warrants further analysis. While it is clear that increased longwave cloud top cooling enhances turbulent mixing in clouds, and thus likely increases the production of liquid water (e.g., Morrison et al., 2012), the effects on ice production are less obvious.

New particle formation (nucleation) occurred about $17 \%$ of the observed time period (Karl et al., 2013), predominantly in air with low aerosol particle concentration and long travel time over the Arctic sea ice. However, these events often occur as a simultaneous increase of particle number concentrations in the $<10 \mathrm{~nm}$ and $20-50 \mathrm{~nm}$ size ranges, and not as the prototypical "banana growth" (cf. e.g. Kulmala et al., 2001). Conventional nucleation paradigms (Karl et al., 2012) fail to explain this behavior. Simultaneous concentration increase at several discrete sub-micrometer particle sizes could be due to vertical mixing of air from different levels above the surface, with different particle size distributions coming from different source regions. An alternate hypothesis explaining this could be fragmentation and/or dispersion of primary marine polymer gels, $\sim 200-500 \mathrm{~nm}$ diameter in size, into the nanogel size fractions down to a few nanometer polymers (Karl et al., 2013; Leck and Bigg, 2010); this appears consistent with the finding of a particle source in the central Arctic being most pronounced in the smallest particles sizes below $26 \mathrm{~nm}$ in diameter (Heintzenberg and Leck, 2012). Fragmentation would be promoted with exposure to ultraviolet light (Orellana et al., 2011) and long travel times over the pack ice. Leck and Bigg $(1999 ; 2010)$ also suggested that disruption of particles by electric charge, such as electrospinning (Reneker and Chun, 1996), might provide an appropriate fragmentation mechanism. This appears consistent with observation since it would be favored by evaporation of cloud or haze drops (e.g., Heintzenberg et al., 2006). Fragmentation hypotheses may also explain why only a few percent of the observed total particle number variability was explained by the direct measurements of particle number fluxes (Held et al., 2011a).

Whereas SML biology was established as one source of airborne aerosols, the fate of these primary marine biogenic particles in interaction with other organic and inorganic particle constituents (Paatero et al., 2009; Chang et al., 2011; Hellén et al., 2012), and if and how they are further processed in the clouds are important topics to revisit. The relative importance of this local or regional primary biological particle source compared to advection from lower latitudes at the MIZ and over the ice-free ocean south thereof, where influences from man-made sources are still limited, remains an open question. More analysis of the ASCOS data, and quite possibly also new observations, will be required before we can determine the balance between these. 
Fundamental for many of these issues is the important question - how representative are the detailed shipborne aerosol measurements, taken at $\sim 25 \mathrm{~m}$ above the surface, for what occurs in the clouds several hundred meters aloft? The answer to this question is related to lower atmosphere mixing processes and the degree to which they couple the cloud and the surface. It may be that locally generated primary marine biogenic particles are important for formation of fog or cloud layer that forms at the top of the surface-based boundary layer, while long-distance advection in the free troposphere and subsequent entrainment is a dominating process for decoupled clouds at a higher altitude. The coupling state varies in time (Tjernström, et al., 2012; Shupe et al., 2013); due to its limited duration ASCOS does not provide a sufficiently large sample to determine the dominant mixing conditions, though ASCOS data may be adequate to examine relationships between measured near-surface aerosol concentrations and the atmospheric coupling state.

Many of the outstanding questions discussed above would benefit greatly from more detailed and comprehensive in situ vertical profiling of clouds and particle properties than what was possible with the helicopter, tethersonde or the NASA DC-8 during ASCOS and AMISA. Providing such detailed profiling capability in the Arctic environment is a major challenge for state-of-the-art instrumentation and flight safety. There is a clear need for instrument development and development of new instrument platforms, such as unmanned aerial vehicles capable of flying in icing conditions with advanced but miniaturized instrumentation. In parallel there is also a obvious need for expanded observations for longer observation campaigns, sampling different time periods that cover different times of the year, to increase the size of the samples, understand processes relevant to other seasons, and to follow the ongoing changes in the Arctic.

Acknowledgements. The Arctic Summer Cloud Ocean Study (ASCOS) was an IPY project under the AICI-IPY umbrella and an endorsed SOLAS project. ASCOS was made possible by funding from the Knut and Alice Wallenberg Foundation, the DAMOCLES Integrated Research Project, EU 6th Framework Programme, while the Swedish Polar Research Secretariat provided access to the icebreaker Oden and logistical support. Support from the US National Science Foundation (NSF) and the National Atmospheric and Oceanic Administration (NOAA) for remote-sensing instruments is gratefully acknowledged. We are also grateful to the Facility for Ground-based Atmospheric Measurement at the UK National Centre for Atmospheric Science for the provision of the sodar and tethered balloon. C. Leck, M. Tjernström, Q. Gao, A. Held, T. Mauritsen and J. Sedlar were funded by the Swedish National Research Council and by the Bert Bolin Centre for Climate Research; M. Tjernström, T. Mauritsen, J. Sedlar and L. Di Liberto also acknowledge support from DAMOCLES. S. Norris, I. Brooks, C. Birch and B. Brooks were funded by the UK Natural Environment Research Council; C. Birch also had support from the UK Met Office. M. Shupe, O. Persson, C. Wheeler, P. Johnston, M. Orellana, P. Matrai, A. Hind and C. Rauschenberg were funded by the NSF; M. Orellana and P. Matrai also acknowledge operational support by the NSF. J. Paatero was supported by the Finnish Meteorological Institute and by the Academy of Finland, the Finnish Academy of Science and the Letters/Vilho, Yrjö and Kalle Väisälä Foundation; FMI also provided several instrument systems. P. Vaattovaara acknowledges funding from the Academy of Finland Centre of Excellence program and from the Finnish Cultural foundation through the Lapland regional fund (Nordenskiöld stipend). A. Sirevaag and S. de la Rosa were supported by the Bjerknes Centre and R. Chang was supported by the Natural Sciences and Engineering Research Council of Canada and Arctic-SOLAS (Canada). The contribution from the Institute for Tropospheric Research was supported by the German Research Foundation (DFG). We are grateful to Jonathan Abbatt, Jan Bottenheim, Erica Key, Ulrike Lohman, Peter Minnette and Marcel Nicolaus for assistance with the measurement program and to the SPRS logistical staff. Finally we are greatly indebted to Oden's Captain Mattias Peterson and his crew for invaluable assistance with many things.

Edited by: K. Carslaw

\section{References}

ACIA: Impacts of a warming Arctic: Arctic Climate Impact Assessment. Cambridge University Press, 1020 pp., 2005.

Albrecht, B.: Aerosols, cloud microphysics and fractional cloudiness, Science, 245, 1227-1230, 1989.

Andreas, E. L., Jordan, R. E., and Makshtas, A. P.: Parameterizing turbulent exchange over sea ice: The Ice Station Weddel results, Bound.-Layer Meteorol., 114, 439-460, 2005.

Berner, A., Lurzer, C., Pohl, F., Preining, O., and Wagner, P.: The size distribution of the urban aerosol in Vienna, Sci. Total Environ., 13, 245-261, 1979.

Bigg, E. K. and Leck, C.: Cloud-active particles over the central Arctic Ocean, J. Geophys. Res., 106, 32155-32166, doi:10.1029/1999JD901152, 2001.

Bigg, E. K. and Leck, C.: The composition of fragments of bubble bursting at the ocean surface, J. Geophys. Res, 113, D11209, doi:10.1029/2007JD009078, 2008.

Bigg, E. K., Leck, C., and Nilsson, E. D.: Sudden changes in arctic atmospheric aerosol concentrations during summer and autumn, Tellus, 48B, 254-271, 1996.

Bigg, E. K., C. Leck, C., and Nilsson, E. D.: Sudden changes in aerosol and gas concentrations in the central Arctic marine boundary layer - Causes and consequences, J. Geophys. Res., 106, 32167-32185, 2001.

Bigg, E. K., Leck, C., and Tranvik, L.: Particulates of the surface microlayer of open water in the central Arctic Ocean in summer, Marine Chem., 91, 131-141, 2004.

Birch, C. E., Brooks, I. M., Tjernström, M., Shupe, M. D., Mauritsen, T., Sedlar, J., Lock, A. P., Milton, S. F., Earnshaw, P., Persson, P. O. G., and Leck, C.: Modelling atmospheric structure, cloud and their response to $\mathrm{CCN}$ in the central Arctic: ASCOS case studies, Atmos. Chem. Phys., 12, 3419-3435, doi:10.5194/acp-12-3419-2012, 2012.

Birmili, W., Stratmann, F., and Wiedensohler, A.: Design of a DMA-based size spectrometer for a large particle size range and stable operation, J. Aerosol Sci., 30, 549-553, 1999. 
Blanchard, D. C.: The electrification of the atmosphere by particles from bubbles in the sea, Prog. Oceanogr., 1, 73-112, 1963.

Blanchard, D. C. and Woodcock, A. H.: Bubble formation and modification in the sea and its meterological significance, Tellus, 9, 145-148, 1957.

Brooks, B. J., Smith, M. H., Hill, M. K., O’Dowd, C. D.: Sizedifferentiated volatility analysis of internally mixed laboratorygenerated aerosol, J. Aerosol. Sci., 33, 555-579, 2002.

Brooks, I. M., Yelland, M. J., Upstill-Goddard, R. C., Nightingale, P. D., Archer, S., d'Asaro, E., Beale, R., Beatty, C., Blomquist, B., Bloom, A. A., Brooks, B. J., Cluderay, J., Coles, D., Dacey, J., DeGrandpre, M., Dixon, J., Drennan, W. M., Gabriele, J., Goldson, L., Hardman-Mountford, N., Hill, M.K., Horn, M., Hsueh, P.-C., Huebert, de Leeuw G., Leighton, T. G., Liddicoat, M., Lingard, J. J. N., McNeil, C., McQuaid, J. B., Moat, B. I., Moore, G., Neill, C., Norris, S. J., O’Doherty, S., Pascal, R. W., Prytherch, J., Rebozo, M., Sahlee, E., Salter, M., Schuster, U., Skjelvan, I., Slagter, H., Smith, M. H., Smith, P. D., Srokosz, M., Stephens, J. A., Taylor, P. K., Telszewski, M., Walsh, R., Ward, B., Woolf, D. K., Young, D., and Zemmelink, H.: Physical Exchanges at the Air-Sea Interface. UK-SOLAS Field Measurements, B. Am. Meteor. Soc., 90, 629-644, 2009.

Chang, R. Y.-W., Leck, C., Graus, M., Müller, M., Paatero, J., Burkhart, J. F., Stohl, A., Orr, L. H., Hayden, K., Li, S.-M., Hansel, A., Tjernström, M., Leaitch, W. R., and Abbatt, J. P. D.: Aerosol composition and sources in the central Arctic Ocean during ASCOS, Atmos. Chem. Phys., 11, 10619-10636, doi:10.5194/acp-11-10619-2011, 2011.

Chapman, W. L. and Walsh, J. E.: Simulations of Arctic temperature and pressure by global coupled models, J. Clim., 20, 609-632, doi:10.1175/JCLI4026.1, 2007.

Charlson, R. J., Lovelock, J. E., Andreae, M. O., and Warren, S. G.: Oceanic phytoplankton, atmospheric sulphur, cloud albedo and climate, Nature, 326, 655-661, 1987.

Chin, W.-C., Orellana, M. V., and Verdugo, P.: Spontaneous assembly of marine dissolved organic matter into polymer gels, Nature, 391, 568-571, 1998.

Clayton, J. R., Dortch, Q., Thoresen, S. S., and Ahmed, S. I.: Evaluation of methods for the separation and analysis of proteins and free amino acids in phytoplankton samples, J. Plankton Res., 10, 341-358, 1988

Comiso, J. C., Parkinson, C. L., Gersten, R., and Stock, L.: Accelerated decline in the Arctic sea ice cover, Geophys. Res. Lett., 35, L01703, doi:10.1029/2007GL031972, 2008.

Covert, D. S., Widensohler., A., Alto, P., Heintzenberg, J., McMurry P. H., and Leck, C.: Aerosol number size distributions from 3 to $500 \mathrm{~nm}$ diameter in the arctic marine boundary layer during summer and autumn, Tellus, 48B, 197-212, 1996.

Coz, E. and Leck, C.: Morphology and state of mixture of atmospheric soot aggregates during the winter season over Southern Asia - a quantitative approach, Tellus, 63, 107-116, doi:10.1111/j.1600-0889.2010.00513.x, 2011.

Curry, J. A. and Ebert, E. E.: Annual cycle of radiative fluxes over the Arctic ocean: Sensitivity to cloud optical properties, J. Clim., 5, 1267-1280, 1992.

Curry, J. A., Rossow, W. B., Randall, D., and Schramm, J. L.: Overview of Arctic cloud and radiation characteristics, J. Atmos. Sci., 9, 1731-1764, 1996.
Decho, A. W.: Microbial exopolymer secretions in ocean environments: Their role(s) in food webs and marine processes, Oceanogr. Mar. Biol. Ann. Rev., 28, 73-153, 1990.

de Gouw, J. and Warneke, C.: Measurements of volatile organic compounds in the Earth's atmosphere using Proton-TransferReaction Mass Spectrometry, Mass Spectrom. Rev., 26, 223257, 2007.

de Leeuw, G., Andreas, E. L., Anguelova, M. D., Fairall, C. W., Lewis, E. R., O'Dowd, C., Schulz, M., and Schwartz, S. E.: Production flux of sea spray aerosol, Rev. Geophys., 49, RG2001, doi:10.1029/2010RG000349, 2011.

Dortch Q., J. R. Clayton, Thorensen, S. S., and Ahmad, S. I.: Species differences in accumulation of nitrogen pools in phytoplankton, Mar. Biol., 81, 237-250, 1984.

Engström, L. E. and Leck, C.: Reducing uncertainties associated with filter-based optical measurement of light absorbing carbon particles with chemical information, Atmos. Meas. Tech., 4, 1567-1580, doi:10.5194/amt-4-1567-2011, 2011

Fer, I.: Scaling turbulent dissipation in an Arctic fjord, Deep-Sea Res. Pt. II, 53, 77-95, 2006.

Fer, I. and Sundfjord, A.: Observations of upper ocean boundary layer dynamics in the marginal ice zone, J. Geophys. Res.Oceans, 112, C04012, doi:10.1029/2005JC003428, 2007.

Fletcher, C. A., Johnson, G. R., Ristovski, Z. D., Harvey, M.: Hygroscopic and volatile properties of marine aerosol observed at Cape Grim during the P2P campaign, Environ. Chem., 4, 162171, doi:10.1071/EN07011, 2007.

Gao, Q., Leck, C., Rauschenberg, C., and Matrai, P. A.: On the chemical dynamics of extracellular polysaccharides in the high Arctic surface microlayer, Ocean Sci., 8, 401-418, doi:10.5194/os-8-401-2012, 2012.

Gao, Q., Araia, M., Leck, C., and Emmer, A.: Characterization of exopoly-saccharides in marine col-loids by capillary electrophoresis with indirect UV detection. Anal. Chim. Acta, 662, doi:10.1016/j.aca.2010.01.008, 2010.

Gard, E., Mayer, J. E., Morrical, B. D., Dienes, T., Fergenson, D. P., and Prather, K. A.: Real-time analysis of individual atmospheric aerosol particles: Design and performance of a portable ATOFMS, Anal. Chem., 69, 4083-4091, 1997.

Garret, T. J., Zhao C., and Novelli, P. C.: Assessing the relative contributions of transport efficiency and scavenging to seasonal variability in Arctic aerosol, Tellus, 62B, 190-196, 2010.

Graus, M., Mueller M., and Hansel, A.: High resolution PTR-TOF: Quantification and formula confirmation of VOC in real time, J. Amer. Soc. Mass Spectrom., 21, 1037-1044, 2010.

Graversen, R. G.: Do changes in the midlatitude circulation have any impact on the Arctic surface air temperature Trend?, J. Clim. 19, 5422-5438, 2006.

Graversen, R. G. and Wang, M.: Polar amplification in a coupled climate model with locked albedo, Clim. Dynam., 33, 629-643, 2009.

Graversen, R. G., Mauritsen, T., Tjernström, M., Källen, E., and Svensson, G.: Vertical structure of recent Arctic warming, Nature, 451, 53-57, 2008.

Greenspan, P. and Fowler, S. D.: Spectrofluorometric studies of the lipid probe, nile red, J. Lipid Res., 26, 781-789, 1985.

Gysel, M., McFiggans, G. B., Coe, H.: Inversion of tandem differential mobility analyser (TDMA) measurements, J. Aerosol Sci., 40, 134-151, 2009. 
Heintzenberg, J.: A Processor-Controlled Multisample Soot Photometer, Aerosol Sci. Techn., 8, 227-233, 1988.

Heintzenberg, J.: Arctic haze: air pollution in polar regions, AMBIO, 18, 50-55, 1989.

Heintzenberg, J. and Leck, C., The summer aerosol in the central Arctic 1991 - 2008: did it change or not?, Atmos. Chem. Phys., 12, 3969-3983, doi:10.5194/acp-12-3969-2012, 2012.

Heintzenberg, J., Leck, C., Birmili, W., Wehner, B., and Tjernström, M., Aerosol number-size distributions during clear and fog periods in the summer high Arctic: 1991, 1996, and 2006, Tellus, 58B, 41-50, 2006.

Held, A., Brooks, I. M., Leck, C., and Tjernström, M.: On the potential contribution of open lead particle emissions to the central Arctic aerosol concentration, Atmos. Chem. Phys., 11, 30933105, doi:10.5194/acp-11-3093-2011, 2011a.

Held, A., Orsini, D. A., Vaattovaara, P., Tjernström, M., and Leck, C.: Near-surface profiles of aerosol number concentration and temperature over the Arctic Ocean, Atmos. Meas. Tech., 4, 1603-1616, doi:10.5194/amt-4-1603-2011, 2011 b.

Hellén, H., Leck, C., Paatero, J., Virkkula, A., and Hakola, H.: Summer concentrations of NMHCs in ambient air of the Arctic and Antarctic, Boreal Environ. Res., 17, 385-397, 2012.

Hill, M. K., Brooks, B. J., Norris, S. J., Smith, M. H., Brooks, I. M., and de Leeuw, G.: A compact lightweight aerosol spectrometer probe (CLASP), J. Atmos. Oceanic Technol., 25, 1996-2006, 2008.

Holland, M. M. and Bitz, C. M.: Polar amplification of climate change in coupled models, Clim. Dyn., 21, 221-232, 2003.

Holm-Hansen, O., Lorenzen, C. J., Holmes, R. W., and Strickland, J. D. H.: Fluorometric determination of chlorophyll, J. Conseil., 30, 3-15, 1965.

Hung, C.-C., Tang, D., Warnken, K., and Santschi, P. H.: Distributions of carbohydrates, including uronic acids, in estuarine waters of Galveston Bay, Mar. Chem., 73, 305-318, 2001.

Hung, C.-C., Guo, L., Santschi, P. H., Alvarado-Quiroz, N. J., and Haye, J.: Distributions of carbohydrate species in the Gulf of Mexico, Mar. Chem., 81, 119-135, 2003.

Hutter, A. R., Larsen, R. J., Maring, H., and Merrill, J. T.: ${ }^{222}$ Rn at Bermuda and Mauna Loa: local and distant sources, J. Radioanal. Nucl. Chem., 193, 309-318, 1995.

Intrieri, J. M., Shupe, M. D., Uttal, T., and McCarthy, B. J.: An annual cycle of Arctic cloud characteristics observed by radar and lidar at SHEBA, J. Geophys. Res., 107, 8039, doi:10.1029/2000JC000423, 2002a.

Intrieri, J. M., Fairall, C. W., Shupe, M. D., Persson, P. O. G., Andreas, E. L., Guest, P. S., and Moritz, R. E.: An annual cycle of Arctic surface cloud forcing at SHEBA, J. Geophys. Res., 107, 8039, doi:10.1029/2000JC000439, 2002b.

IPCC: Climate Change 2007: The Physical Science Basis, Contribution of Working Group I to the Fourth Assessment Report of the Intergovernmental Panel on Climate Change, edited by: Solomon, S., Qin, D., Manning, M., Chen, Z., Marquis, M., Averyt, K. B., Tignor, M. and Miller, H. L., Cambridge University Press, Cambridge, UK and New York, NY, USA, 996 pp., 2007.

IPCC, 2013: Climate Change 2013: The Physical Science Basis. Contribution of Working Group I to the Fifth Assessment Report of the Intergovernmental Panel on Climate Change, edited by: Stocker, T. F., Qin, D., Plattner, G.-K., Tignor, M., Allen, S. K., Boschung, J., Nauels, A., Xia, Y., Bex, V., and Midgley, P.M.,
Cambridge University Press, Cambridge, UK and New York, NY, USA, 1535 pp., 2013.

Joutsensaari, J., Vaattovaara, P., Vesterinen, M., Hämeri, K., and Laaksonen, A.: A novel tandem differential mobility analyzer with organic vapor treatment of aerosol particles, Atmos. Chem. Phys., 1, 51-60, doi:10.5194/acp-1-51-2001, 2001.

Karl, M., Leck, C., Gross, A., and Pirjola, L.: A study of new particle formation in the marine boundary layer over the central Arctic ocean using a flexible multicomponent aerosol dynamic model, Tellus, 64B, 17158, doi:10.3402/tellusb.v64i0.17158, 2012.

Karlsson, J. and Svensson, G.: The simulation of Arctic clouds and their influence on the winter surface temperature in present-day climate in the CMIP3 multi-model dataset, Clim. Dynam., 36, 623-635, 2011.

Kapsch, M.-L., Graversen, R. G., and Tjernström, M.: Springtime atmospheric energy transport and the control of Arctic summer sea-ice extent, Nature Clim. Change, 3, 744-748, doi:10.1038/nclimate1884, 2013.

Kay, J. E. and Gettelman, A.: Cloud influence on and response to seasonal Arctic sea ice loss, J. Geophys. Res., 114, D18204, doi:10.1029/2009JD011773, 2009.

Kay, J. E,'Ecuyer, T. L, Gettelman, A., Stephens, G., and O’Dell, C.: The contribution of cloud and radiation anomalies to the 2007 Arctic sea ice extent minimum, Geophys. Res. Let., 35, L08503, doi:10.1029/2008GL033451, 2008.

Keil, R. G. and Kirchman, D. L.: Dissolved combined aminoacids in marine waters as determined by a vapor-phase hydrolysis method. Mar. Chem., 33, 243-259, 1991.

Kerminen, V.-M. and Leck, C.: Sulfur chemistry over the Central Arctic Ocean in summer: Gas to particulate transformation, J. Geophys. Res., 106, 32087-32100, 2001.

Knap, A., Michaels, A., Close, A., Ducklow, H., and Dickson, A. (eds.): Protocols for the Joint Global Ocean Flux Study (JGOFS) Core Measurements, JGOFS Report Nr. 19, 170 pp., 1996.

Knulst, J. C., Rosenberger, D., Thompson, B., and Paatero, J.: Intensive sea surface microlayer investigations of open leads in the pack ice during Arctic Ocean 2001 Expedition., Langmuir, 19, 10194-10199, 2003.

Krembs, C., Deming, J. W., Junge, K., and Eicken, H.: High concentrations of exopolymeric substances in wintertime sea ice: Implications for the polar ocean carbon cycle and cryoprotection of diatoms, Deep-Sea Res., 49, 2163-2181, 2002.

Kulmala, M., Dal Maso, M., Mäkelä, J. M., Pirjola, L., Väkevä, M., Aalto, P. P., Miikkulainen, P., Hämeri, K., and O'Dowd, C. F.: On the formation, growth and composition of nucleation mode particles, Tellus, 53B, 479-490, 2001.

Kupiszewski, P., Leck, C., Tjernström, M., Sjogren, S., Sedlar, J., Graus, M., Müller, M., Brooks, B., Swietlicki, E., Norris, S., and Hansel, A.: Vertical profiling of aerosol particles and trace gases over the central Arctic Ocean during summer, Atmos. Chem. Phys., 13, 12405-12431, doi:10.5194/acp-13-12405-2013, 2013.

Kwok, R., Cunningham, G. F., Wensnahan, M., Rigor, I., Zwally, H. J., and Yi, D: Thinning and volume loss of Arctic sea ice: 2003-2008, J. Geophys. Res., 114, C07005, doi:10.1029/2009JC005312, 2009.

Lannefors, H., Heintzenberg, J., and Hansson, H.-C.: A comprehensive study of physical and chemical parameters of the Arctic summer aerosol; results from the Swedish expedition Ymer-80, Tellus 35B, 40-54, 1983. 
Leck, C. and Bigg, E. K.: Aerosol production overremote marine areas - A new route, Geophys. Res. Lett., 23, 3577-3581, 1999.

Leck, C. and Bigg, E. K.: Evolution of the marine aerosol - A new perspective, Geophys. Res. Lett., 32, L19803, doi:10.1029/2005GL023651, 2005a.

Leck, C. and Bigg, E. K.: Biogenic particles in the surface microlayer and overlaying atmosphere in the central Arctic Ocean during summer, Tellus, 57B, 305-316, doi:10.1111/j.16000889.2005.00148.x, 2005b.

Leck, C. and Bigg, E. K.: A modified aerosol-cloudclimate feedback hypothesis, Environ. Chem., 4, 400-403, doi:10.1071/EN07061, 2007.

Leck, C. and Bigg, E. K.: New particle formation of marine biological origin, Aerosol Sci. Tech., 44, 570-577, 2010.

Leck, C. and Persson, C.: Seasonal and short-term variability in dimethyl sulfide, sulphur dioxide and biogenic sulphur and sea salt aerosol particles in the arctic marine boundary layer, during summer and autumn, Tellus 48B, 272-299, 1996a.

Leck, C. and Persson, C.: The central Arctic Ocean as a source of dimethyl sulfide Seasonal variability in relation to biological activity, Tellus B, 48, 156-177, 1996b.

Leck, C., Larsson, U., Bågander, L. E., Johansson, S., and Hajdu, S.: Dimethyl sulfide in the Baltic Sea: Annual variability in relation to biological activity, J. Geophys. Res., 95, 3353-3363, doi:10.1029/JC095iC03p03353, 1990.

Leck, C., Bigg, E. K., Covert, D. S., Heintzenberg, J., Maenhaut, W., Nilsson, E. D., and Wiedensohler, A.: Overview of the atmospheric research program during the International Ocean Expedition of 1991 (IAOE-1991) and its scientific results, Tellus, 48B, 136-155, 1996.

Leck, C., Nilsson, E. D., Bigg, E. K., and Bäcklin, L.: The atmospheric program of the Arctic Ocean Expedition 1996 (AOE1996) - an overview of scientific objectives, experimental approaches and instruments, J. Geophys. Res., 106, 32051-32067, 2001.

Leck, C., Norman, M., Bigg, E. K., and Hillamo, R.: Chemical composition and sources of the high Arctic aerosol relevant for fog and cloud formation, J. Geophys. Res., 107, AAC 1-1-AAC 117, doi:10.1029/2001JD001463, 2002.

Leck, C., Tjernström, M., Matrai, P., and Swietlicki, E.: Microbes, clouds and climate: Can marine microorganisms influence the melting of the Arctic pack ice?, EOS Transactions, 85, 25-36, 2004.

Leifer, I., de Leeuw, G., and Cohen, L. H.: Optical measurement of bubbles: System design and application, J. Atm. Ocean. Tech. 20, 1317-1332, 2003.

Lindinger, W., Hansel, A., and Jordan, A.: On-line monitoring of volatile organic compounds at pptv levels by means of ProtonTransfer-Reaction Mass-Spectrometry (PTR-MS): Medical applications, food control and environmental research. Int. J. Mass Spectrom., 173, 191-241, 1998.

Lindsay, R. W. and Zhang, J.: The thinning of Arctic sea ice 19882003: Have we passed a tipping point?, J. Clim., 18, 4879-4894, 2005.

Liu, Y., Key, J. R., and Wang, X.: The influence of changes in cloud cover on recent surface temperature trends in the Arctic, J. Clim., $21,705-715,2008$.
Lohmann, U. and Leck, C., Importance of submicron surface-active organic aerosols for pristine Arctic clouds, Tellus, 57B, 261-268, doi:10.1111/j.1600-0889.2005.00144.x, 2005.

Lundén, J., Svensson, G., Wisthaler, A., Tjernström, M., Leck, C., and Hansel, A.: The vertical distribution of atmospheric DMS in the high Arctic summer, Tellus, 62B, 160-171, doi:10.1111/j.1600-0889.2010.00458.x, 2010

Maenhaut, W., Hillamo, R., Mäkelä, T., Jaffrezo, J.-L., Bergin, M. H., and Davidson, C. I.: A new cascade impactor for aerosol sampling with subsequent PIXE analysis, Nucl. Instrum. Meth. B., 109/110, 482-487, 1996.

Martin M., Chang, R. Y.-W., Sierau, B., Sjogren, S., Swietlicki, E., Abbatt, J. P. D., Leck, C., and Lohmann, U.: Cloud condensation nuclei closure study on summer arctic aerosol, Atmos. Chem. Phys., 11, 11335-11350, doi:10.5194/acp-11-11335-2011, 2011.

Matrai, P. A. and Keller, M. D.: Dimethylsulfide in a large-scale cocolithophore bloom in the Gulf of Maine, Cont. Shelf Res., 13, 831-843, 1993

Mattsson, R., Paatero, J., and Hatakka, J.: Automatic alpha/beta analyser for air filter samples - absolute determination of radon progeny by pseudo-coincidence techniques, Rad. Prot. Dos., 63, 133-139, 1996.

Mauritsen, T., Sedlar, J., Tjernström, M., Leck, C., Martin, M., Shupe, M., Sjogren, S., Sierau, B., Persson, P. O. G., Brooks, I. M., and Swietlicki, E.: An Arctic CCN-limited cloud-aerosol regime, Atmos. Chem. Phys., 11, 165-173, doi:10.5194/acp-11165-2011, 2011.

McPhee, M. G.: Air-ice-ocean interaction: Turbulent boundary layer exchange processes, Springer, New York, 215 pp., 2008.

Minnett, P. J., Knuteson, R. O., Best, F. A., Osborne, B. J., Hanafin, J. A., and Brown, O. B.: The Marine-Atmospheric Emitted Radiance Interferometer (M-AERI), a high-accuracy, seagoing infrared spectroradiometer, J. Atmos. Oceanic Technol., 18, 994 1013, 2001.

Mopper, K. and Dawson, R.: Determination of amino acids in seawater - Recent chromatographic developments and future directions, Sci. Total Environ., 49, 115-131, 1986.

Mopper, K., Zhou, J., Sri Ramana, K., Passow, U., Dam, H. G., and Drapeau, D. T.: The role of surface-active carbohydrates in the flocculation of a diatom bloom in a mesocosm, Deep-Sea Res. II, 42, 47-73, 1995.

Moran, K. P., Martner, B. E., Post, M. J., Kropfli, R. A., Welsh, D. C., and Widener, K. B.: An unattended cloud-profiling radar for use in climate research, B. Am. Meteor. Soc., 79, 443-455, 1998.

Morrison, H., de Boer, G., Feingold, G., Harrington, J., Shupe, M. D., and Sulia, K.: Resilience of persistent Arctic mixed-phase clouds, Nature Geosciences, 5, 11-17, doi:10.1038/NGEO1332, 2012.

Myklestad, S. M., Skånøy, E., and Hestmann, S.: A sensitive and rapid method for analysis of dissolved mono- and polysaccharides in seawater, Marine Chem., 56, 279-286, 1997.

Nicolaus, M., Hudson, S. R., Gerland, S., and Munderloh, K. A modern concept for autonomous and continuous measurements of spectral albedo and transmittance of sea ice, Cold Reg. Sci. Technol., 62, 14-28, doi:10.1016/j.coldregions.2010.03.001, 2010

Nilsson, E., Swietlicki, E., Sjogren, S., Löndahl, J., Nyman, M., and Svenningsson, B.: Development of an H-TDMA for longterm unattended measurement of the hygroscopic properties of 
atmospheric aerosol particles, Atmos. Meas. Tech., 2, 313-318, doi:10.5194/amt-2-313-2009, 2009.

Nilsson, E. D.: Planetary boundary layer structure and air mass transport during the International Arctic Ocean Expedition, 1991. Tellus, 48, 178-196, 1996.

Nilsson, E. D. and Leck, C.: A pseudo-Lagrangian study of the sulfur budget in the remote Arctic marine boundary layer, Tellus, 54b, 213-230, 2002.

Nilsson, E. D. and Rannik, Ü.: Turbulent aerosol fluxes over the Arctic Ocean, 1: dry deposition over sea and pack ice, J. Geophys. Res., 106, 32125-32137, doi:10.1029/2000JD900605, 2001.

Norris, S. J., Brooks, I. M., de Leeuw, G., Sirevaag, A., Leck, C., Brooks, B. J., Birch, C. E., and Tjernström, M.: Measurements of bubble size spectra within leads in the Arctic summer pack ice. Ocean Sci., 7, 129-139, doi:10.5194/os-7-129-2011, 2011.

Ogren, J. A. and Heintzenberg, J.: Parametric aerosol sampling at low concentration levels, Rep. AA-1, Dep. of Meteorol., Stockholm Univ., Stockholm, 1990.

Ovadnevaite, J., Ceburnis, D., Martucci, G., Bialek, J., Monahan, C., Rinaldi, M., Facchini, M. C., Berresheim, H.,Worsnop, D. R., and O'Dowd, C.: Primary marine organic aerosol: A dichotomy of low hygroscopicity and high CCN activity, Geophys. Res. Lett., 38, L21806, doi:10.1029/2011GL048869, 2011.

Overland, J. E.: The case for global warming in the Arctic, in: Influence of climate change on the changing Arctic and sub-Arctic conditions, Nato Science for Peace and Security Series - C: Environmental Security, edited by: Nihoul, J. C. J. and Kostianoy, A. G., Springer, the Netherlands, 13-23, 2009.

Overland. J. E., Wood, K. R., and Wang, M.: Warm Arctic-cold continents: climate impacts of the newly open Arctic Sea, Polar Res., 30, 15787, doi:10.3402/polar.v30i0.15787, 2011.

Orellana, M. V., and Verdugo, P.: Ultaviolet radiation blocks the organic carbon exchange between the dissolved phase and the gel phase in the ocean, Limnol Oceanogr. , 48, 1618-1623, 2003.

Orellana, M. V., Petersen, T. W., Diercks, A. H., Donohue, S., Verdugo, P., and van den Engh, G.: Marine microgels: Optical and proteomic fingerprints, Mar. Chem. Marine Chem., 105, 229239, 2007.

Orellana, M. V., Matrai, P. A., Leck, C., Rauschenberg, C. D., Lee, A. M., and Coz, E.: Marine microgels: a source of CCN in the high Arctic, PNAS, 33, 13612-13617, doi:10.1073/pnas.1102457108, 2011.

Paatero, J., Vaattovaara, P., Vestenius, M., Meinande, O., Makkonen, U., Kivi, R., Hyvärinen, A., Asmi, E., Tjernström, M., and Leck, C.: Finnish contribution to the Arctic Summer Cloud Ocean Study (ASCOS) expedition, Arctic Ocean 2008, Geophysica, 45, 119-146, 2009.

Packard, T. T. and Dortch, Q.: Particulate protein-nitrogen in North Atlantic surface water, Mar. Biol., 33, 347-354, 1975.

Persson, P. O. G.: Summary of meteorological conditions during the Arctic Mechanisms for the Interaction of the Surface and Atmosphere (AMISA) intensive operation periods, NOAA Technical Memorandum OAR PSD-314, 57 pp., 2010.

Persson, P. O. G., Fairall, C. W., Andreas, E. L., Guest, P. S., and Perovich, D. K.: Measurements near the Atmospheric Surface Flux Group tower at SHEBA: Near-surface conditions and surface energy budget, J. Geophys. Res. 107, 8045, doi:10.1029/2000JC000705, 2002.
Perovich, D. K., Richter-Menge, J. A., Jones, K. F., and Light, B.: Sunlight, water, and ice: extreme Arctic sea ice melt during the summer of 2007, Geophys. Res. Lett., 35, L11501, doi:10.1029/2008GL034007, 2008.

Philippin, S., Wiedensohler, A., and Stratmann, F.: Measurements of non-volatile fractions of pollution aerosols with an eight-tube volatility tandem differential mobility analyzer (VTDMA-8), J. Aerosol Sci., 35, 185-203, 2004.

Prather, K. A., Nordmeyer, T., and Salt, K.: Real-time characterization of individual aerosol particles using time-offlight mass spectrometry, Anal. Chem., 66, 1403-1407, doi:10.1021/ac00081a007, 1994.

Polyakov, I., Timokhov, L., Hanse, E., Piechura, J., Walczowski, W., Ivanov, V., Simmons, H., Fahrbach, E., Hölemann, J., Steel, M., Pickart, R., Fortier, L., Schauer, U., Beszczynska-Möller, A., Holliday, N. P., Dmitrenko, I., Dickson, R., Gascard, J. C., and Mauritzen, C.: Observational program tracks Arctic Ocean transition to a warmer state, EOS Trans., 88, 398-399. doi:10.1029/2007EO400002, 2007.

Reneker, D. H. and Chun, I.: Nanometre diameter fibres of polymer, produced by electrospinning, Nanotechnology, 7, 216-223, 1996.

Richter-Menge, J. and Jeffries, M., The Arctic in: State of the Climate 2010, B. Am. Meteorol. Soc., 92, S143-S160, 2011.

Roberts, G. C. and Nenes, A.: A continuous-flow streamwise thermal-gradient $\mathrm{CCN}$ chamber for atmospheric measurements, Aerosol Sci. Technol., 39, 206-221, doi:10.1080/027868290913988, 2005.

Rose, D., Wehner, B., Ketzel, M., Engler, C., Voigtländer, J., Tuch, T., and Wiedensohler, A.: Atmospheric number size distributions of soot particles and estimation of emission factors, Atmos. Chem. Phys., 6, 1021-1031, doi:10.5194/acp-6-1021-2006, 2006.

Rose, D., Gunthe, S. S., Mikhailov, E., Frank, G. P., Dusek, U., Andreae, M. O., and Pöschl, U.: Calibration and measurement uncertainties of a continuous-flow cloud condensation nuclei counter (DMT-CCNC): CCN activation of ammonium sulfate and sodium chloride aerosol particles in theory and experiment, Atmos. Chem. Phys., 8, 1153-1179, doi:10.5194/acp-8-11532008, 2008.

Sedlar, J. and Tjernström, M.: Stratiform cloud-inversion characterization during the Arctic melt season, Bound.-Lay. Meteorol., 132, 455-474, doi:10.1007/s10546-009-9407-1, 2009.

Sedlar, J., Shupe, M. D., and Tjernström, M.: On the Relationship between thermodynamic structure and cloud top, and its climate significance in the Arctic, J. Clim., 25, 2374-2393, doi:10.1007/s00382-010-0937-5, 2012.

Sedlar, J., Tjernström, M., Mauritsen, T., Shupe, M. D., Brooks, I. M., Birch, C. E., Leck, C., Sirevaag, A., and Persson, P. O. G.: A transitioning Arctic surface energy budget: the impacts of solar zenith angle, surface albedo and cloud radiative forcing, Clim. Dyn., 37, 1643-1660, doi:10.1007/s00382-010-0937-5, 2011.

Serreze, M. C. and Barry, R. G.: Processes and impacts of Arctic amplification: A research synthesis, Global and Planetary Change, 77, 85-96, doi:10.1016/j.gloplacha.2011.03.004, 2011.

Serreze, M. C. and Francis, J. A.: The Arctic amplification debate, Clim. Change, 76, 241-264, 2006. 
Serreze, M. C., Holland, M. M., and Stroeve, J.: Perspectives on the Arctic's shrinking sea-ice cover. Science, 315, 1533-1536, doi:10.1126/science.1139426, 2007.

Shaw, G. E. and Khalil, M. A. K.: Arctic haze, in: The Handbook of Environmental Chemistry, edited by: Hutzinger, O., Springer Verlag, Berlin, Heidelberg, 4B, 70-111, 1989.

Shimada, K.: Pacific Ocean inflow: Influence on catastrophic reduction of sea ice cover in the Arctic Ocean, Geophys. Res. Let., 33, L08605, doi:10.1029/2005GL025624, 2006.

Shupe, M. D. and Intrieri, J. M.: Cloud radiative forcing of the Arctic surface: The influence of cloud properties, surface albedo, and solar zenith angle, J. Climate, 17, 616-628, 2004.

Shupe, M. D., Kollias, P., Poellot, M., and Eloranta, E.: On deriving vertical air motions from cloud radar Doppler spectra, J. Atmos. Ocean. Technol., 25, 547-557, 2008.

Shupe, M. D., Persson, P. O. G., Brooks, I. M., Tjernström, M., Sedlar, J., Mauritsen, T., Sjogren, S., and Leck, C.: Cloud and boundary layer interactions over the Arctic sea-ice in late summer, Atmos. Chem. Phys., 13, 9379-9400, doi:10.5194/acp-139379-2013, 2013.

Shupe, M. D., Valden, V. P., Eloranta, E., Uttal, T., Campbell, J. R., Starkweather, S. M., and Masataka, M.: Clouds at Arctic atmospheric observatories, Part I: Occurrence and macrophysical properties, J. Appl. Meteor. Clim., 50, 626-644, 2011.

Shupe, M. D., Brooks, I. M., and Canut, G.: Evaluation of turbulent dissipation rate retrievals from doppler cloud radar, Atmos. Meas. Tech. Discuss., 5, 747-774, doi:10.5194/amtd-5747-2012, 2012.

Sirevaag, A., de la Rosa, S., Fer, I., Nicolaus, M., Tjernström, M., and McPhee, M. D.: Mixing, heat fluxes and heat content evolution of the Arctic Ocean mixed layer. Ocean Sci., 7, 335-349, doi:10.5194/os-7-335-2011, 2011.

Sorteberg, A., Furevik, T., Drange, H., and Kvamstø, N. G.: Effects of simulated natural variability on Arctic temperature projections, Geophys. Res. Let., 32, L18708, doi:10.1029/2005GL023404, 2005.

Stephens, G. L.: Cloud feedbacks in the climate system: A critical review, J. Clim., 18, 237-273, 2005.

Stetzer, O., Baschek, B, Lüönd, F., and Lohmann, U.: The Zurich ice nucleation chamber (ZINC) - A new instrument to investigate atmospheric ice formation. Aerosol Sci. Tech., 42, 64-74, 2008.

Stolzenburg, M. R.: An Ultrafine Aerosol Size distribution system, Ph.D. thesis, University of Minnesota, Minneapolis, MN, 1988.

Tjernström, M.: The summer Arctic boundary layer during the Arctic Ocean Experiment 2001 (AOE-2001), Bound.-Layer Meteorol., 117, 5-36, 2005.

Tjernström, M.: Is there a diurnal cycle in Arctic summer cloudcapped boundary layer?, J. Atmos. Sci., 64, 3974-3990, 2007.

Tjernström, M. and Mauritsen, T.: Mesoscale variability in the summer Arctic boundary layer. Bound.-Lay. Meteorol., 130, 383406, doi:10.1007/s10546-009-9354-x, 2009.

Tjernström, M., Sedlar, J., and Shupe, M. D.: How well do regional climate models reproduce radiation and clouds in the Arctic? An evaluation of ARCMIP simulations, J. Appl. Meteorol. Clim., 47, 2405-2422, 2008.

Tjernström, M., Leck, C., Persson, P. O. G., Jensen, M. L., Oncley, S. P., and Targino, A.: The summertime Arctic atmosphere: Meteorological measurements during the Arctic Ocean Exper- iment (AOE-2001), Bull Amer. Meteor. Soc., 85, 1305-1321, doi:10.1175/BAMS-85-9-1305, 2004a.

Tjernström, M., Leck, C., Persson, P. O. G., Jensen, M. L., Oncley, S. P., and Targino, A.: Experimental equipment: An electronic supplement to "The summertime Arctic atmosphere: Meteorological measurements during the Arctic Ocean Experiment (AOE-2001)", Supplement, B. Am. Meteor. Soc., 85, doi:10.1175/BAMS-85-9-1305, 2004a.

Tjernström, M., Birch, C. E., Brooks, I. M., Shupe, M. D., Persson, P. O. G., Sedlar, J., Mauritsen, T., Leck, C., Paatero, J., Szczodrak, M., and Wheeler, C. R.: Meteorological conditions in the central Arctic summer during the Arctic Summer Cloud Ocean Study (ASCOS), Atmos. Chem. Phys., 12, 6863-6889, doi:10.5194/acp-12-6863-2012, 2012.

Tjernström, M., Zagar, M., Svensson, G., Cassano, J. C., Pfeifer, S., Rinke, A., Wyser, K., Dethloff, K., Jones, C., Semmler, T., and Shaw, M.: Modelling the Arctic boundary layer: An evaluation of six ARCMIP regional-scale models using data from the SHEBA project, Bound.-Lay. Meteorol., 117, 337-381, 2005.

Twomey, S. A.: The influence of pollution on the shortwave albedo of clouds, J. Atmos. Sci., 34, 1149-1152, 1977.

Vaattovaara, P., Räsänen, M., Kühn, T., Joutsensaari, J., and Laaksonen, A.: A method for detecting the presence of organic fraction in nucleation mode sized particles, Atmos. Chem. Phys., 5, 3277-3287, doi:10.5194/acp-5-3277-2005, 2005.

Vaattovaara, P., Huttunen, P. E., Yoon, Y. J., Joutsensaari, J., Lehtinen, K. E. J., O'Dowd, C. D., and Laaksonen, A.: The composition of nucleation and Aitken modes particles during coastal nucleation events: evidence for marine secondary organic contribution, Atmos. Chem. Phys., 6, 4601-4616, doi:10.5194/acp-64601-2006, 2006

Verdugo, P.: Marine Microgels, Ann. Rev. Marine Sci., 4, 375-400, 2012.

Walsh, J., Kattsov, V., Chapman, W., Govorkova, V., and Pavlova, T.: Comparison of Arctic climate simulations by uncoupled and coupled global models, J. Clim., 15, 1429-1446, 2002.

Wang, X., and Key, J. R.: Arctic surface, cloud, and radiation properties based on the AVHRR polar pathfinder data set. Part I: Spatial and temporal characteristics, J. Clim., 18, 2558-2574, 2005.

Wehner, B., Philippin, S., Wiedensohler, A., Scheer, V., and Vogt, R.:, Variability of non-volatile fractions of atmospheric aerosol particles with traffic influence, Atmos. Environ., 38, 6081-6090, 2004.

Westwater, E. R., Han, Y., Shupe, M. D., and Matrosov, S. Y.: Analysis of integrated cloud liquid and precipitable water vapor retrievals fro microwave radiometers during the Surface Heat Budget of the Arctic Ocean project, J. Geophys. Res., 106, 3201932030, 2001.

Westwater, E., Han, Y., Irisov, V. G., Leuskiy, V., Kadygrov, E. N., and Viazankin, S. A.: Remote sensing of boundary layer temperature profiles by a scanning $5-\mathrm{mm}$ microwave radiometer and RASS: Comparison experiments, J. Atmos. Ocean. Tech., 16, 805-818, 1999.

White, A. B., Jordan, J., Martner, B., Ralph, F., and Bartram, B.: Extending the dynamic range of an S-band radar for cloud and precipitation studies, J. Atmos. Ocean. Tech., 17, 1226-1234, 2000.

Wilczak, J. M., Oncley, S. P., and. Stage, S. A: Sonic anemometer tilt correction algorithms. Bound.-Lay. Meteorol., 99, 127 - 150, 2001. 
Xin, L., Leck, C., Sun, L., Hede, T., Tu, Y., and Ågren, H.: Cross-Linked Polysaccharide Assemblies in Marine Gels: An Atomistic Simulation, J. Phys. Chem. Lett., 4, 2637-2642, doi:10.1021/jz401276r, 2013.

Zhang, X., Sorteberg, A., Zhang, J., Gerdes, R., and Comiso, J. C.: Recent radical shifts of atmospheric circulations and rapid changes in Arctic climate system, Geophys. Res. Let., 35, L22701, doi:10.1029/2008GL035607, 2008.

Zhou J., Mopper, K., and Passow, U.: The role of surface-active carbohydrates in the formation of transparent exopolymer particles by bubble adsorption of seawater, Limnol. Oceanogr., 43, 18601871, 1998.
Zygmuntowska, M., Mauritsen, T., Quaas, J., and Kaleschke, L.: Arctic clouds and surface radiation - a critical comparison of satellite retrievals and the ERA-Interim reanalysis, Atmos. Chem. Phys., 12, 6667-6677, doi:10.5194/acp-12-6667-2012, 2012. 


\section{Appendix A}

\section{Detailed description of the measurement systems}

\section{A1 Meteorology}

The meteorology program had three major aims: (i) to provide scientific data on clouds, boundary-layer structure and surface energy balance; (ii) to provide background information on meteorological conditions and development as support for the other observations; (iii) to provide operational guidance during the field phase for the activities on the ice and for different sampling strategies, for example use of the helicopter, turning of the icebreaker and planning of the AMISA missions.

ASCOS operational planning was supported by the Swedish Meteorological and Hydrological Institute (SMHI) providing surface forecast maps from the European Centre for Medium-Range Weather Forecasts (ECMWF) and wind forecast for our location. Additionally the UK Met Office provided daily tailored column forecasts at our location for a number of forecast variables, including clouds, from the Unified Model. Finally, the HYSPLIT email-trajectory service was utilized to generate forecast back-trajectories for sampling strategy (see http://ready.arl.noaa.gov/HYSPLIT_email.php). All of these products were transferred over email using Iridium satellite telephone data transfer.

Two weather stations, regular radiosoundings and many other instruments were deployed to track the evolving meteorology as well as providing background information for remote-sensing observation system retrievals (Table A1). Both weather stations on the seventh deck measured standard meteorological parameters while one also featured radiation sensors on a gimbaled platform. Additional sensors included a visibility sensor and cloud ceilometer, a so-called "present weather" sensor and an all-sky camera. Radiosoundings were carried out every $6 \mathrm{~h}$; a few additional soundings were performed during AMISA flyovers (Persson, 2010) and for the helicopter flights. A subset of soundings were augmented to carry ozone or radioactivity sensors; these were launched with a larger balloon for higher maximum altitude. To our knowledge, radioactivity soundings had not previously been performed this far north (Paatero et al., 2009). The sounding ground station was located on the seventh deck while the soundings were launched from the helipad.

To study the energy exchange at the surface and connections between cloud and surface processes, a micrometeorological site was established on the ice near the ice breaker about $400 \mathrm{~m}$ away from the ship (Table A2). The main features of this site were two masts with turbulence and profile instrumentation, a tethered sounding site, a surface radiation and sodar site and a physical oceanography site (see below). A $15 \mathrm{~m}$ mast was equipped with five levels of sonic anemometers for measurement of three-dimensional turbulent winds and so-called sonic temperature, a close approximation to the virtual temperature. Two levels also had fast open-path humidity and $\mathrm{CO}_{2}$ instruments, while three other levels had fine-wire thermocouple sensors for fast measurement of temperature. Nearby, a $30 \mathrm{~m}$ mast deployed a single sonic anemometer with heated transducers at the top. All turbulence measurements were sampled at $20 \mathrm{~Hz}$. On the $15 \mathrm{~m}$ mast a thermocouple string in aspirated radiation shields measured the vertical temperature gradient profile; there were also two levels with aspirated and radiation shielded absolute temperature and relative humidity sensors. Atmospheric pressure and GPS position were also measured by the base of the $15 \mathrm{~m}$ mast.

Turbulent fluxes were derived by eddy-correlation after the sonic anemometer wind-speed components had been corrected for sensor tilt using the "planar-fit" correction (Wilczak et al., 2001). Heat fluxes were calculated using both the sonic temperature and, where available, the finewire thermocouple sensors. Using the sonic temperature to determine the sensible heat flux strictly requires a correction determined from the coincident moisture-flux measurements; however, here this correction was not applied. Although the relative humidity was high, absolute humidity was low in this cold environment, the correction is small and the difference between buoyancy and sensible-heat fluxes is negligible (Andreas et al., 2005). Variances and covariances were evaluated over 10-min averaging intervals, after a linear detrending of the signals. An additional turbulent flux measurement site was established on the ice edge close to the "Open Lead" site (Table A3). It consisted of a sonic anemometer, openpath $\mathrm{H}_{2} \mathrm{O} / \mathrm{CO}_{2}$ sensor, and a condensation particle counter to allow estimation of total aerosol particle fluxes (see below).

A stand with two pyranometer and two pyrgeometer sensors measuring broadband up- and downwelling surface short- and longwave radiation was deployed at an undisturbed location away from the masts. Between this stand and the $15 \mathrm{~m}$ mast, 12 thermocouple temperature sensors were spread out on the snow close to the surface. Of these, six were white-capped to minimize solar heating, two were capped in aluminum foil, two painted black and two were left exposed. A string of white-capped thermocouples was located close to the radiation stand to measure a temperature profile in the upper $1 \mathrm{~m}$ of the ice. White heat-shrink covered the outer $40-50 \mathrm{~cm}$ of cables to minimize heat conduction in the wire. Note that due to melting of snow and snowfall during the deployment, the depths of the surface temperature sensors had to be readjusted several times and the surface temperatures are therefore somewhat approximate. Two surface heat-flux plates were also deployed here, at the snow/ice interface.

A tethered balloon-borne profiling system was also operated at "Met Alley" (Table A4). This system consisted of a helium-filled SkyDoc aerostat, providing both static and dynamic lift. An instrument package was suspended $10 \mathrm{~m}$ below the balloon, which was anchored to a winch on the surface allowing the system to operate from the surface to 
Table A1. List of basic meteorological instruments on board Oden. Two weather stations were operated: one supplied by the Rosenstiel School of Marine and Atmospheric Science (RSMAS) and one permanently on board. Additional sensors were deployed by the Finnish Meteorological Institute (FMI).

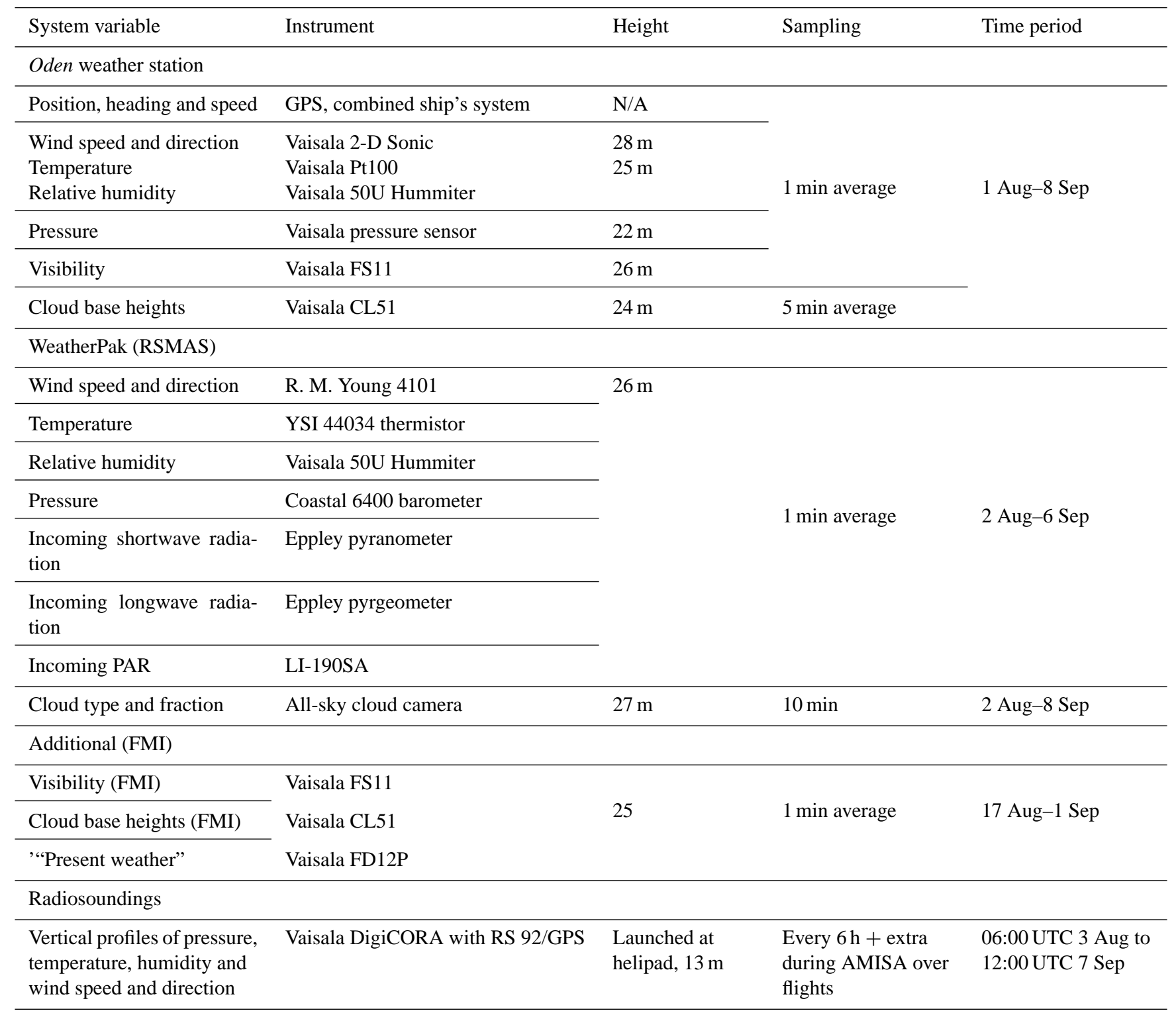

$\sim 700 \mathrm{~m}$; the maximum height depended on wind speed and was limited by the combined weight of instruments payload and tethering line. The instrument package was built around a Gill sonic anemometer in a factory-made aerodynamic housing. Additional sensors in the same housing include those for atmospheric pressure, mean temperature and relative humidity, GPS position and instrument package motion; a digital camera set for slow time-lapse photography was also attached. Data were logged and stored on board by custombuilt control electronics designed in-house. On some flights an integrated aerosol size-distribution sensor, CLASP (Hill et al., 2008), was also operated. The anemometer was sampled at $10 \mathrm{~Hz}$ so that in addition to profiles of mean variables the tethered system also provided a measure of the turbulence the turbulent kinetic energy dissipation rate from the inertial subrange portion of wind-speed power spectra.

For the continuous monitoring of wind, temperature, cloud and some turbulence estimates, a suite of surface-based remote sensors was deployed on Oden and on the ice (Table A5). To observe boundary layer vertical structure and winds, a phased-array Doppler sodar was deployed in a noise abatement shield on the ice close to the radiation site. The sodar operates by sending audible sound pulses in and off the vertical, retrieving both backscattered power from the 
Table A2. List of micrometeorological instrumentation at the "Met Alley" site.

\begin{tabular}{|c|c|c|c|c|}
\hline Variables & Instrument & Heights & Sampling & Time period \\
\hline $\begin{array}{l}\text { 3-D winds and sonic tem- } \\
\text { perature, turbulent fluxes } \\
\text { of momentum and sensible } \\
\text { heat }\end{array}$ & $\begin{array}{lrl}\text { Gill } & \text { R3 } & \text { ultrasonic } \\
\text { anemometer } & \end{array}$ & 4.04 and $15.4 \mathrm{~m}$ & \multirow{5}{*}{$20 \mathrm{z}$} & 16 August-1 September \\
\hline -“" & $\begin{array}{l}\text { Campbell CSAT3 sonic } \\
\text { anemometer }\end{array}$ & $0.94,5.21$ and $8.19 \mathrm{~m}$ & & 13 August-1 September \\
\hline -“" & $\begin{array}{l}\text { METEK Research } 300 \\
\text { sonic anemometer } \\
\text { heated sensor heads }\end{array}$ & $30.6 \mathrm{~m}$ & & 15 August-1 September \\
\hline $\begin{array}{l}\text { Fast humidity and } \mathrm{CO}_{2} \text {, tur- } \\
\text { bulent fluxes of water and } \\
\mathrm{CO}_{2}\end{array}$ & $\begin{array}{l}\text { LI-COR } 7500 \text { open path an- } \\
\text { alyzer }\end{array}$ & 4.04 and $15.4 \mathrm{~m}$ & & 16-31 August \\
\hline $\begin{array}{l}\text { Fast temperature, turbulent } \\
\text { fluxes of sensible heat }\end{array}$ & $\begin{array}{l}\text { Campbell FW3 Type E fine- } \\
\text { wire thermocouple }\end{array}$ & $0.94,5.21$ and $8.19 \mathrm{~m}$ & & \multirow{4}{*}{13 August-1 September } \\
\hline $\begin{array}{l}\text { Temperature gradient pro- } \\
\text { file }\end{array}$ & In situ thermocouple string & $\begin{array}{l}0.20,1.02,1.79,5.32 \text { and } \\
8.36 \mathrm{~m}\end{array}$ & \multirow{3}{*}{055} & \\
\hline $\begin{array}{l}\text { Absolute temperature and } \\
\text { relative humidity }\end{array}$ & Rotronic & 3.19 and $14.92 \mathrm{~m}$ & & \\
\hline Atmospheric pressure & Vaisala & surface & & \\
\hline $\begin{array}{l}\text { Surface radiation short- } \\
\text { wave, up and down }\end{array}$ & Eppley pyranometers & $1.5 \mathrm{~m}$ & \multirow{5}{*}{$1 \mathrm{~Hz}$} & \multirow{2}{*}{15 August-1 September } \\
\hline $\begin{array}{l}\text { Surface radiation longwave, } \\
\text { up and down }\end{array}$ & Eppley pyrgeometers & $1.5 \mathrm{~m}$ & & \\
\hline Surface temperatures & Thermocouple & $8 @ \sim-0.05 \mathrm{~m}$ & & \multirow{3}{*}{13 August-1 September } \\
\hline $\begin{array}{l}\text { Ice temperature gradient } \\
\text { profile }\end{array}$ & Thermocouple & $\begin{array}{l}-0.05,-0.15,-0.40 \text { and } \\
-1 \mathrm{~m}\end{array}$ & & \\
\hline Surface heat conduction & $\begin{array}{l}\text { Hukseflux HFP01SC sur- } \\
\text { face heat-flux plates }\end{array}$ & $2 @ \sim-0.05 \mathrm{~m}$ & & \\
\hline
\end{tabular}

emitted pulses and their Doppler frequency shift. Being an acoustic instrument, it had to be deployed on the ice since it is sensitive to noise on board a ship. The backscattered power provides information about boundary-layer turbulence structure while the Doppler shift can be used to derive the threedimensional wind vector. The sodar has a high vertical and temporal resolution, but, as it relies on backscatter generated by turbulence, it was mostly restricted to measuring winds in the boundary layer. For winds aloft, a wind-profiling radar was deployed on board the ship. This was the first shipborne deployment of such a system. Its operation is similar to that of the sodar, but using radar wavelengths, at $449 \mathrm{MHz}$, sensitive to absolute humidity fluctuations. The choice of wavelength is optimized for dry Arctic conditions.

A $60 \mathrm{GHz}$ scanning microwave radiometer (Westwater et al., 1999) was deployed on the starboard bridge-wing roof (seventh deck). This instrument operates on a wavelength in- sensitive to water vapor and clouds, and passively senses atmospheric brightness temperatures averaged over some distance away from the sensor, scanning over different angles to the horizon. From this information temperature profiles through the boundary layer are retrieved. Given a temperature profile, the radiometer signal is unique but the opposite is not true. The retrieval works from a "first-guess" temperature profile, in ASCOS taken from the 6-hourly soundings. The retrieved profiles therefore gradually adjust to interpolated sounding profiles with height; the retrieval therefore provides additional information beyond a simple interpolation of radiosonde measurements for the periods between soundings, at high temporal resolution $(5 \mathrm{~min})$ up to $\sim 700 \mathrm{~m}$. Simple geometrical considerations show that the vertical resolution degrades with height; close to the surface it is theoretically $\sim 10 \mathrm{~m}$, degrading to $\mathrm{O}(100 \mathrm{~m})$ above $500 \mathrm{~m}$. 
Table A3. Summary of the meteorological and oceanography instruments at the "Open Lead" aerosol flux site.

\begin{tabular}{|c|c|c|c|c|}
\hline Variables & Instrument & Height & Sampling & In operation \\
\hline Bubble size spectra & Mini-BMS & $-0.7 \mathrm{~m}$ & $20 \mathrm{~Hz}$ in $2 \mathrm{~m}, \mathrm{~min}$ bursts & $\begin{array}{l}\text { 17-21, 26-27, 29-31 August } \\
\text { and } 1 \text { September. }\end{array}$ \\
\hline $\begin{array}{l}\text { 3-D winds and sonic tem- } \\
\text { perature, turbulent fluxes } \\
\text { of momentum and sensible } \\
\text { heat }\end{array}$ & $\begin{array}{l}\text { Gill R3 ultrasonic } \\
\text { anemometer }\end{array}$ & $2.5 \mathrm{~m}$ & $20 \mathrm{~Hz}$ & \multirow[t]{3}{*}{17 August-1 September } \\
\hline $\begin{array}{l}\text { Fast humidity and } \mathrm{CO}_{2} \text {, tur- } \\
\text { bulent fluxes of water and } \\
\mathrm{CO}_{2}\end{array}$ & $\begin{array}{l}\text { LI-COR } 7500 \text { open } \\
\text { path analyzer }\end{array}$ & $2.5 \mathrm{~m}$ & $20 \mathrm{~Hz}$ & \\
\hline $\begin{array}{l}\text { Aerosol number concentra- } \\
\text { tion }\end{array}$ & CPC TSI-3760 & $2.5 \mathrm{~m}$ & $10 \mathrm{~Hz}$ & \\
\hline $\begin{array}{l}\text { Temperature and aerosol } \\
\text { gradients }\end{array}$ & $\begin{array}{l}\text { "Gradient pole" - } \\
\text { CPC TSI-3101 }\end{array}$ & N/A & N/A & 26-31 August, 1 September \\
\hline
\end{tabular}

Table A4. List of instruments for the tethered sounding package. This package was operated semi-continuous, weather and manpower permitting, and operated from the surface up to $500 \mathrm{~m}$; 77 individual flights were made totaling $210 \mathrm{~h}$ of operation.

\begin{tabular}{llll}
\hline Variables & Instrument & Sampling In operation \\
\hline $\begin{array}{lll}\text { 3-D winds, sonic temperature, turbulent } \\
\text { fluxes of momentum and sensible heat }\end{array}$ & Gill WindMaster ultrasonic anemometer & $10 \mathrm{~Hz}$ \\
\hline Atmospheric pressure & Intersema MS5540B & \\
\cline { 1 - 3 } Absolute temperature and relative humidity & Sensirion SHT7x & $1 \mathrm{~Hz}$ & \multirow{2}{*}{ Quasi-continuously, } \\
\hline GPS position & Garmin GPS15L receiver & $1 \mathrm{~Hz}$ & $10 \mathrm{~Hz}$ \\
\hline Instrument package motion & PNI MicroMag compass & \\
& ADIS16251 rate gyro & \\
& ST LIS3LV02DQ 3-axis accelerometer & \\
\hline Aerosol concentration and size distribution & CLASP & $10 \mathrm{~Hz}$ \\
\hline
\end{tabular}

Remote sensing of cloud microphysics requires a multisenor approach; the centerpiece is a vertically pointing $\mathrm{Ka}$ band Doppler Millimeter Cloud Radar (MMCR, Moran et al., 1998). The MMCR measures backscattered power and Doppler velocity spectra from the hydrometeors in each measuring volume and is very sensitive. From these observations, the total backscattered power, the mean Doppler velocity and the Doppler spectrum width (the square root of the Dopplervelocity variance within a sampling volume) are derived. Under certain conditions, the MMCR can also be used to detect in-cloud turbulence (Shupe et al., 2008, 2012). A cloud ceilometer located nearby is used to detect the height to the lowest liquid-water cloud layer and a dual-wavelength (24 and $31 \mathrm{GHz}$ ) microwave radiometer measures atmospheric brightness temperatures from which the precipitable water vapor and liquid water path (PWV and LWP) are derived (Westwater et al., 2001); this information constrains the retrieval of liquid water profiles from the MMCR. The com- bination of these sensors provides cloud boundaries, cloud thermodynamic phase, and cloud microphysical properties such as water content and characteristic hydrometeor size. An S-band cloud and precipitation radar (White et al., 2000) was additionally deployed, mainly as a backup. It is less sensitive than the MMCR but is rugged and was successfully operated in the Arctic during the AOE-2001 (e.g., Tjernström et al., 2004a, b).

A Marine-Atmospheric Emitted Radiance Interferometer (M-AERI; Minnett et al., 2001) was deployed on the seventh deck, on the roof of the port bridge wing, with an unobstructed view from the surface to the sky. The M-AERI is a Fourier-transform infrared interferometer adapted to operate for long durations at sea on the deck of a ship, while maintaining a high level of absolute accuracy. It operates in the $\sim 3$ to $\sim 18 \mu \mathrm{m}$ range of the infrared spectrum, passively measuring brightness temperatures with a high spectral resolution, while using two internal blackbody cavities 
Table A5. Summary of the meteorological surface-based remote-sensing instruments.

\begin{tabular}{|c|c|c|c|c|}
\hline Variables & Instrument & Operating principle & $\begin{array}{l}\text { Temporal/spatial res- } \\
\text { olution }\end{array}$ & $\begin{array}{l}\text { Time period and loca- } \\
\text { tion }\end{array}$ \\
\hline $\begin{array}{l}\text { Wind speed and direc- } \\
\text { tion, boundary layer } \\
\text { structure }\end{array}$ & $\begin{array}{l}\text { Scintec MFAS, } \\
\text { phased array sodar }\end{array}$ & $\begin{array}{l}\text { Active, phased array, } \\
\text { vertical and off verti- } \\
\text { cal Doppler sodar at } \\
\text { alternating frequency, } \\
1650-2750 \mathrm{~Hz}\end{array}$ & $\begin{array}{l}10 \mathrm{~min} \text { averages } / 30 \text { to } \\
\sim 600 \mathrm{~m} \text { at } 10 \mathrm{~m} \text { reso- } \\
\text { lution, }\end{array}$ & $\begin{array}{l}17 \text { Aug-1 Sep, on ice } \\
\text { by radiation stand }\end{array}$ \\
\hline $\begin{array}{l}\text { Wind speed and direc- } \\
\text { tion }\end{array}$ & $\begin{array}{l}\text { Wind profiler, NOAA } \\
\text { in-house design }\end{array}$ & $\begin{array}{l}\text { Active, phased array, } \\
\text { vertical and off verti- } \\
\text { cal Doppler radar at } \\
449 \mathrm{MHz}\end{array}$ & $\begin{array}{l}30 \mathrm{~min} \quad \text { aver- } \\
\text { ages } / 144 \mathrm{~m}-\sim 3 \mathrm{~km} \text { at } \\
30 \mathrm{~m} \text { resolution }\end{array}$ & $\begin{array}{l}15 \text { Aug-8 Sep, on } \\
\text { board on foredeck lab } \\
\text { roof }\end{array}$ \\
\hline $\begin{array}{l}\text { Cloud reflectivity and } \\
\text { boundaries, precip- } \\
\text { itation hydrometeor } \\
\text { Doppler fall velocity }\end{array}$ & $\begin{array}{l}\text { MMCR Doppler Mil- } \\
\text { limeter Cloud Radar, } \\
\text { NOAA design }\end{array}$ & $\begin{array}{lr}\text { Active, } & \text { vertically } \\
\text { pointing } & \text { Doppler } \\
\text { radar at } & 35 \mathrm{GHz} \\
\text { (Ka-band) } & \end{array}$ & $\begin{array}{l}0.03 \mathrm{~Hz} / 95 \mathrm{~m}- \\
14.3 \mathrm{~km} \text { at } 45 \mathrm{~m} \\
\text { resolution }\end{array}$ & $\begin{array}{l}3 \text { Aug-8 Sep, on } \\
\text { board on foredeck lab } \\
\text { roof }\end{array}$ \\
\hline $\begin{array}{l}\text { Cloud reflectivity and } \\
\text { boundaries, precip- } \\
\text { itation hydrometeor } \\
\text { Doppler fall velocity }\end{array}$ & $\begin{array}{l}\text { Doppler cloud and } \\
\text { precipitation radar, } \\
\text { NOAA in-house } \\
\text { design }\end{array}$ & $\begin{array}{lr}\text { Active, } & \text { vertically } \\
\text { pointing } & \text { Doppler } \\
\text { radar at } & 2.875 \mathrm{GHz} \\
\text { (S-band) } & \end{array}$ & $\begin{array}{l}2 \mathrm{~min} . \text { ave. } / \text { two set- } \\
\text { tings: } 57 \mathrm{~m}-2.2 \mathrm{~km} \text { or } \\
230 \mathrm{~m}-8.5 \mathrm{~km} \text { at } 60 \text { or } \\
105 \mathrm{~m} \text { resolution }\end{array}$ & $\begin{array}{l}3 \text { Aug-8 Sept, on } \\
\text { board on foredeck } \\
\text { CTD container roof }\end{array}$ \\
\hline $\begin{array}{l}\text { Vertical temperature } \\
\text { profiles }\end{array}$ & $\begin{array}{l}\text { Microwave radiome- } \\
\text { ter, NOAA in-house } \\
\text { design }\end{array}$ & $\begin{array}{l}\text { Passive, scanning in } \\
\text { the vertical plane, } \\
\text { sensing at } 60 \mathrm{GHz}\end{array}$ & $\begin{array}{l}5 \mathrm{~min} . \quad \text { ave } . / 15 \mathrm{~m}- \\
1.2 \mathrm{~km} \text { at variable } \\
\text { resolution: } \sim 10 \mathrm{~m} \text { at } \\
\text { surface to } \sim \mathrm{O}(100 \mathrm{~m}) \\
\text { at } 1 \mathrm{~km}\end{array}$ & $\begin{array}{l}4 \text { Aug-7 Sep, on } \\
\text { board on starboard } \\
\text { wing of seventh deck }\end{array}$ \\
\hline $\begin{array}{l}\text { Frequency-resolved } \\
\text { brightness temper- } \\
\text { ature of surface, } \\
\text { environment } \\
\text { sky and } \\
\text { horizontal viewing } \\
\text { angles) }\end{array}$ & $\begin{array}{l}\text { Marine-Atmospheric } \\
\text { Emitted Radiance } \\
\text { Interferometer (M- } \\
\text { AERI) }\end{array}$ & $\begin{array}{l}\text { Passive, Fourier } \\
\text { transform infrared } \\
\text { interferometer, } \\
\text { frequency-resolved } \\
\text { brightness tempera- } \\
\text { ture at preset angles }\end{array}$ & $\begin{array}{l}11 \text { min ave./vertically } \\
\text { integrating in the } \sim 3 \\
\text { to } \sim 18 \mu \mathrm{m} \text { range at } \\
\sim 0.5 \mathrm{~cm}^{-1} \text { spectral } \\
\text { resolution }\end{array}$ & $\begin{array}{l}2 \text { Aug-8 Sep, on } \\
\text { board on port wing of } \\
\text { seventh deck }\end{array}$ \\
\hline $\begin{array}{l}\text { Integrated liquid wa- } \\
\text { ter and precipitable } \\
\text { water vapor }\end{array}$ & $\begin{array}{l}\text { Dual-wavelength mi- } \\
\text { crowave radiometer }\end{array}$ & $\begin{array}{l}\text { Passive sensing at } 24 \\
\text { and } 31 \mathrm{GHz}\end{array}$ & Vertically integrated & $\begin{array}{l}2 \text { Aug-8 Sep, fore- } \\
\text { deck lab roof }\end{array}$ \\
\hline $\begin{array}{l}\text { Aerosol and cloud } \\
\text { particles and phase }\end{array}$ & MuLID micro-lidar & $\begin{array}{l}\text { Active lidar } 35 \mu \mathrm{J} \text { at } \\
532 \mathrm{~nm} \text {, w/ depolar- } \\
\text { ization }\end{array}$ & $\begin{array}{l}5 \mathrm{~min} \text { ave. } / 0-1850 \mathrm{~m} \\
\text { at } 2 \mathrm{~m}\end{array}$ & 2-24 August \\
\hline
\end{tabular}

for accurate real-time calibration. The scene mirror directs the field of view to either of the blackbody calibration targets or to the environment. In ASCOS the mirror was programmed to view horizontally and $\pm 45^{\circ}$, up and down. The horizontal and downward views essentially provide air and surface temperatures, respectively, while the upward view provides spectral information from the atmosphere. The MuLID was also deployed on the port side wing on the seventh deck. This instrument measures aerosol backscatter and depolarization ratio at the $532 \mathrm{~nm}$ wavelength. Finally, ultraviolet radiation was measured on the roof of the sounding station above the seventh deck with a NILU-UV multiband filter radiometer. The instrument has five channels with nominal center wavelengths at 305, 313, 320, 340, $380 \mathrm{~nm}$, and an additional channel (400-700 nm) for the measurement of photosynthetically active radiation (PAR).

\section{A2 Atmospheric chemistry and aerosol physics}

The atmospheric chemistry and physics programs were primarily concerned with determining the role of marine biochemical sources for CCN and IN formation, with emphasis on the open lead surface microlayer, and to determine the evolution of CCN and IN, how they form cloud droplets and ice crystals and partition water between the liquid and solid 
Table A6. Atmospheric chemistry - gases.

\begin{tabular}{ll}
\hline Sensors/variables & Instrument \\
\hline $\begin{array}{l}\mathrm{DMS} \text { (ship and helicopter) } \\
\mathrm{SO}_{2} \text { (ship) }\end{array}$ & PTR-TOFMS/GC/FPD \\
HPLC/FD
\end{tabular}

Table A7. Atmospheric chemistry - aerosol.

\begin{tabular}{|c|c|}
\hline Variables & Instrument system \\
\hline Aerosol mass size distribution $\left(D_{50}: 25 \mathrm{~nm}-10 \mu \mathrm{m}\right)$ : & 5-stage BCI, 13-stage LPI, 2-stage SFU, 1-stage FP and TSP \\
\hline Major soluble ions & IC \\
\hline $\begin{array}{l}\text { Saccharides, Amino acids and proteins, microgel } \\
\text { abundance }\end{array}$ & Ultrafiltration/LC-MS/MS, HRGC-HRMS, TEM/SEM/Biotechn \\
\hline Trace metals & $\mathrm{PM}_{10} / \mathrm{ICP}-\mathrm{MS}$ \\
\hline Polycyclic aromatic hydrocarbons: e.g., PAH & $\mathrm{PM}_{10} / \mathrm{GC} /$ mass detector \\
\hline $\mathrm{BC}\left(D_{50}<2 \mu \mathrm{m}\right)$ & $\begin{array}{l}\text { Photometer detection of light absorption at } \lambda=550 \mathrm{~nm} / 1 \text {-stage filter unit } \\
\text { with PCMB filters. }\end{array}$ \\
\hline Gravimetric mass $\left(D_{50}<10 \mu \mathrm{m}\right.$ and $\left.D_{50}<1 \mu \mathrm{m}\right)$ & CAHN-microbalance/TSP, 1-stage filter unit \\
\hline Non-refractory chemical mass $\left(D_{50}: 70 \mathrm{~nm}-0.7 \mu \mathrm{m}\right)$ & C-ToF-AMS \\
\hline $\begin{array}{l}\text { Single particle chemical composition }\left(D_{50}: 10 \mathrm{~nm}-\right. \\
1 \mu \mathrm{m})\end{array}$ & $\begin{array}{l}\text { TEM/SEM/DIA /Collection by dual impactors, one electrostatic } \\
\text { precipitator and one nanosampler (TSI) }\end{array}$ \\
\hline $\begin{array}{l}\text { Single particle chemical composition }\left(D_{50}: 200 \mathrm{~nm}-\right. \\
3 \mu \mathrm{m})\end{array}$ & ATOFMS \\
\hline $\begin{array}{l}\text { Inferred chemical composition and state of mixture } \\
D_{50}: 20 \mathrm{~nm}-9 \mu \mathrm{m}\end{array}$ & SMPS and OPC-volatility instruments \\
\hline Nascent particulate matter $D_{50}<1 \mu \mathrm{m}$ (“Open Lead") & SEA-CATAMARAN, SEM/TEM, LC-MS/MS \\
\hline $\begin{array}{l}\text { Bubble generated nascent particulate matter } \\
D_{50}<1 \mu \mathrm{m} \text { ("Open Lead") }\end{array}$ & Laboratory glass tower ( $2 \mathrm{~m}$ in height) \\
\hline
\end{tabular}


Table A8. Atmospheric aerosol - physical and cloud active properties.

\begin{tabular}{ll}
\hline Variables & Instrument system \\
\hline Aerosol number size distribution $\left(D_{50}: 3 \mathrm{~nm}-10 \mu \mathrm{m}\right)$ & $\begin{array}{l}\text { UDMPS: UDMA + UCPC (TSI 3025), DMPS: DMA + CPC (TSI 3010): } \\
\text { SMPS (DMS + CPC), APS, OPC, Grimm-EDM, fast-response UCPC (TSI } \\
3025)\end{array}$ \\
\hline $\begin{array}{l}\text { Vertical aerosol number and cloud/fog structure } \\
\left(D_{50}: 3 \mathrm{~nm}-30 \mu \mathrm{m}\right)\end{array}$ & $\begin{array}{l}\text { Micro-lidar (MuLID, see Table A5), and helicopter mounted counters } \\
(\text { UCPC }(\text { TSI-3025 })+\text { CPC (TSI-7610) + CLASP) }\end{array}$ \\
\hline CCN spectrum and IN & CCNC DMT $(\times 2) /$ PINC ETH \\
\hline Cloud/fog size distribution $\left(D_{50}: 1-47 \mu \mathrm{m}\right)$ & FSSP-100A \\
\hline Cloud active properties $\left(D_{50}: 6 \mathrm{~nm}-1 \mu \mathrm{m}\right)$ & H-TDMA/VH-TDMA/UFO-TDMA/TDMPS \\
\hline $\begin{array}{l}\text { Aerosol particle fluxes from water and ice } \\
\left(D_{50}: 11 \mathrm{~nm}-3 \mu \mathrm{m}\right)\end{array}$ & $\begin{array}{l}\text { Eddy-covariance system }(\mathrm{CPC} \text { TSI-3760 and a Sonic anemometers, LI- } \\
\text { COR open path analyzer), gradient pole }(\mathrm{CPC} \text { TSI-3010) }\end{array}$ \\
\hline Fog water analysis & Microgel abundance and size distribution: SEM/TEM/LC-MS/MS \\
\hline Cloud water analysis & Microgel abundance and size distribution, pH: SEM/TEM/LC-MS/MS \\
\hline
\end{tabular}

Table A9. Summary of the physical oceanography instruments at the "Met Alley" site.

\begin{tabular}{|c|c|c|c|c|}
\hline Variables & Instrument & Height & Sampling & In operation \\
\hline $\begin{array}{l}\text { 3-D velocity, turbulent fluxes } \\
\text { of momentum, sensible heat } \\
\text { and salinity }\end{array}$ & ADVOcean, Sontek/YSI & $-3.8,-7.8$ and $-9.6 \mathrm{~m}$ & $2 \mathrm{~Hz}$ & 14-31 August \\
\hline Fast-response temperature & SBE3, SeaBird Electronics & & & \\
\hline Conductivity (salinity) & SBE7, SeaBird Electronics & & & \\
\hline $\begin{array}{l}\text { Vertical structure (tempera- } \\
\text { ture, salinity and mixing) }\end{array}$ & $\begin{array}{l}\text { MSS-90 ISW } \\
\text { Wassermesstechnik }\end{array}$ & Continuous profiling $0--500 \mathrm{~m}$ & $1024 \mathrm{~Hz}$ & \\
\hline $\begin{array}{l}\text { Spectral surface albedo and } \\
\text { transmission }\end{array}$ & RAMSES ACC Trios GmbH, & Above and below ice & & \\
\hline
\end{tabular}

phase. The programs attempted a specification of most of the aerosol particle sources as well as the chemical properties, morphology and state of mixture of the aerosol particles, and to understand the processes involved in the particles becoming capable of cloud drop formation. The specific goals were to

- harvest the open lead microlayer film and to collect the surface bulk water at depths down to ca $50 \mathrm{~cm}$

- examine and evaluate the presence and properties of bubble populations in the upper water column, their dependence on environmental conditions and the capacity of the open leads to emit particles to the air

- make shipboard measurements of the chemical and physical properties of aerosol and cloud-active particles, sampled in air and cloud/fog
- measure concentrations of gases that might participate in aqueous-phase condensation, with or without oxidation.

- sample vertical profiles and horizontal variation of aerosol particles and gases.

The next sections will discuss the instrumentation required for meeting these needs. The complete set of instruments used during the expedition is listed in Table 2. The headings of the subsections (Sects. A2.1-A2.3) below match the headings used in Table 2 and Tables A6-A8. If not otherwise indicated, instruments were located in the aerosol container on the port side of the fourth deck of Oden. Unless otherwise noted, the onboard measurements were operational throughout the expedition, occasionally interrupted by pollution episodes (also see Table 4). 


\section{A2.1 Atmospheric chemistry: gases (Table A6)}

Sulfur dioxide. $\mathrm{SO}_{2}$ was monitored with a modified automated real-time Saltzman et al. (1993) technique involving HPLC/FD. To avoid potential surface losses, sub-micrometer aerosol particles were filtered out. Reproducibility was $4.5 \%$ at $20 \operatorname{ppt}(\mathrm{v})$ and $\pm 20 \%$ at $5 \operatorname{ppt}(\mathrm{v})$ (the detection limit) respectively. The instrument sampled off the $\mathrm{PM}_{1}$ inlet and was located in the first chemistry container on the fourth deck of Oden.

Ozone. The technique for shipborne $\mathrm{O}_{3}$ monitoring was based on UV absorption and performed by two monitors operating in parallel, both sampling with 1 min time resolution off the $\mathrm{PM}_{1}$ inlet. Additionally eight vertical $\mathrm{O}_{3}$ soundings with electrochemical ozone sensors were released. A third UV absorption instrument for in situ sampling of surface level $\mathrm{O}_{3}$ was deployed on the top of the aerosol container during the transit and at the Open Lead site during the drift. This instrument was part of the OOTI package that also included an atomic absorption instrument measuring mercury a well as a MAXDOAS primary deployed to measure bromine monoxide. The sampling rate was between 5 and $15 \mathrm{~min}$. The OOTI was battery powered and fully automated.

Volatile organic compounds. VOCs including DMS, acetonitrile, acetone and various pollution markers such as benzene, toluene and xylene, were measured with a PTRTOFMS built at Innsbruck University. The instrument was used both for quasi-continuous observations on board, in the second chemistry container on the fourth deck (Fig. 5), and for analysis of canister samples obtained during vertical profiling by the helicopter. The PTR-TOFMS technique is a well-established method for fast online VOC analysis (Lindinger et al., 1998; de Gouw and Warneke, 2007) in the atmosphere. The instrument used in this study is described in detail in Graus et al. (2010). The PTR-TOFMS was calibrated by applying a dynamically diluted VOC gas standard (Apel \& Riemer Environmental Inc); zero-calibrations were performed every $2-6 \mathrm{~h}$ using catalytically scrubbed air. The PTR-TOFMS co-sampled next to the main sampling manifold described in Sect. 6 through a Teflon filter and a heated $6.4 \mathrm{~mm}$ Sulfinert ${ }^{\circledR}($ Restek Performance Coating) tubing with a residence time of $<3 \mathrm{~s}$.

Radon-222. ${ }^{222} \mathrm{Rn}$ can be used as a tracer for air that has been in contact with land. Using a US Department of Homeland Security, Environmental Measurements Laboratory instrument based on the in-growth and subsequent alpha counting of short-lived ${ }^{222} \mathrm{Rn}$ progeny, it was measured every hour on the seventh deck of Oden. The sample air was pumped through a high efficiency particulate air filter, which removed all the radionuclides, including short-lived ${ }^{222} \mathrm{Rn}$ progeny, attached to ambient aerosol particles. ${ }^{222} \mathrm{Rn}$, being a noble gas, passed through this filter. Next the air entered a $500 \mathrm{~L}$ delay chamber where part of the ${ }^{222} \mathrm{Rn}$ decayed to its short-lived daughter nuclides. These nuclides are heavy metals and were trapped by a second filter. The alpha particles emitted by the collected daughter nuclides were finally counted with a scintillation detector (Hutter et al., 1995).

Non-methane hydrocarbons. NMHCs play a key role in the photochemistry of the remote atmosphere and play an important role for the production of $\mathrm{O}_{3}$. The sampling for NMHCs was conducted on the seventh (uppermost) deck, on the upwind side of the ship. Air samples were collected into $0.85 \mathrm{~L}$ canisters using a Teflon membrane pump. In total 36 canisters were collected. The samples were analyzed later in the laboratory using a GC/FID with a $\mathrm{Al}_{2} \mathrm{O}_{3} / \mathrm{KCl}$ PLOT column. Prior to analyses, samples were pre-concentrated in two liquid nitrogen traps: in a stainless steel loop with glass beads and in a capillary trap. To remove $\mathrm{CO}_{2}$, the sample was passed through a $10 \mathrm{~cm}$-long stainless steel tube filled with $\mathrm{K}_{2} \mathrm{CO}_{3}$ and $\mathrm{NaOH}$. Calibration was performed using a gaseous standard from the UK National Physical Laboratory containing 27 hydrocarbons and analyzed as regular samples. It was not possible to measure alkenes, since they are formed in the canisters during the storage.

\section{A2.2 Atmospheric chemistry: aerosol (Table A7)}

Chemical characterization of nascent aerosol from artificial bubble bursting on board Oden. Bubble experiments were performed in the permanent laboratory on the third deck (foredeck) of Oden, using a modified method by Mopper et al. (1995). Seawater without pre-filtration was fed directly into a pre-cleaned glass tower ( $2 \mathrm{~m}$ high and $15.3 \mathrm{~cm}$ wide). Purified zero air was forced into the system through a sintered glass frit (nominal pore size $15-25 \mu \mathrm{m}$ ) at the bottom of the tower at a flow rate of $150 \mathrm{~mL} \mathrm{~min}^{-1}$. This flow rate enabled production of a sufficient number of bubbles with diameter $\sim 300 \mu \mathrm{m}$, to mimic natural conditions (Norris et al., 2011). The purpose of this experiment, unlike that by Mopper et al. (1995), was to simulate accumulation of SML material by bubbles rising in the water column, and the air flow was therefore kept constant. Throughout the $1 \mathrm{~h}$ bubbling period aerosol particles, generated by bursting bubbles, were collected on a pre-combusted glass plate at $\sim 10 \mathrm{~cm}$ above the water surface. The particles on the glass plate were carefully rinsed with ultra-purified (Milli-Q) water into a pre-cleaned polycarbonate tube and frozen (to $-80^{\circ} \mathrm{C}$ ).

Chemical characterization of nascent aerosol from artificial bubble bursting at the air sea interface. From a floating platform at the "Open Lead site", approximately $2 \mathrm{~m}$ from the edge of the ice floe, filtered particle-free air was released through two porous heads located $10-20 \mathrm{~cm}$ below the water surface. Two filter holders were placed above the bubble bursting region at a height of $10-30 \mathrm{~cm}$ above the water surface. An electrostatic precipitator, collecting particles for subsequent SEM/TEM analyses, was located between the two filter holders and the sampling durations were varied from $30 \mathrm{~min}$ to $3 \mathrm{~h}$.

Chemical size distributions (mass). Aerosol bulk chemical composition resolved over size was determined from one 
filter group that sampled off the $\mathrm{PM}_{1}$ inlet. This group used duplicate filter pack cassettes, FP (Millipore Teflon filter, $1.0 \mu \mathrm{m}$ poor size), in which one filter served as a blank. In addition one FP was used for collection of total $\mathrm{PM}_{1}$ mass for subsequent gravimetrical analyses, and a special filter stack unit (PCMB filters) for collecting BC. Also for gravimetrical analyses we collected TSP $\left(\mathrm{PM}_{10}\right)$ with both $D_{50}<10 \mu \mathrm{m}$ EAD and $>2 \mu \mathrm{m}$ EAD. A FP and a 2-stage SFU (Maenhaut et al., 1996) were used, respectively.

To obtain further size resolution, a second group of collectors sampled off the $\mathrm{PM}_{10}$ inlet was used. It included (1) quadruplicate 5 -stage high-volume $\left(80 \mathrm{dm}^{3} \mathrm{~min}^{-1}\right)$, lowpressure BCI (Berner et al., 1979) that collected particles with cut points of $D_{50} 10,5.0,2,1.2,0.161$ and $<0.161 \mu \mathrm{m}$ EAD (the latter was serving as a backup filter); and (2) one 13-stage ( $\left.30 \mathrm{dm}^{3} \mathrm{~min}^{-1}\right)$, LPI (Dekati, http://dekati.com/ $\mathrm{cms} /$ ) with cut points of $D_{50} 10,6.57,3.96,2,45,1,60$, $0.990,0.634,0.391,0.253,0.165,0.104,0.060$ and 0.029 EAD. Tedlar films (DuPont ${ }^{\mathrm{TM}}$ ) were used as the collection substrate in the BCI except for the backup filter that consisted of one $47 \mathrm{~mm}$ Millipore Teflon filter (1.0 $\mu \mathrm{m}$ pore size). The LPI used polycarbonate collection foils. To avoid supermicrometer particles bouncing off, the Tedlar stage-5 (BCI) and the polycarbonate stages 11-13 were greased (Apiezon$\mathrm{L}$ dissolved in acetone).

The BCIs and FP collected sufficient material for analysis in $4 \mathrm{~h}$ in the early parts of the expedition; later sampling times had to be increased to as long as $12 \mathrm{~h}$. The BCI samples thus have the highest time resolution of all size-resolved chemical bulk samples (in total 48) performed during ASCOS. The FP, EC, TSP, and SFU samplers, and the more detailed size segregated LPI impactor, required significantly longer sampling times, $12-72 \mathrm{~h}$, so that 18 sampling periods were obtained. Blank levels were determined by loading the impactor with the substrates at the sampling site for the length of the sampling period with zero flow.

Ambient samples and blanks were carefully handled in a glove box both prior to and after sampling. Analyses of the filter/substrate extracts (FP, STP, BCI and LPI) were performed with IC used for quantitative aerosol inorganic analyses (Engström and Leck, 2011). At the time of the IC analyses, still in the glove box, the filters were extracted (in centrifuge tubes) with $5 \mathrm{~cm}^{3}$ deionized water $(18 \mathrm{M} \Omega \mathrm{cm})$. For sufficient extraction the filter extracts were finally placed in an ultra-sonic bath for $60 \mathrm{~min}$.

The BC content was derived from a comparison of $550 \mathrm{~nm}$ light intensity transmitted through samples and blank filters (Engström and Leck, 2011) using an integrating plate photometer (Heintzenberg, 1988). For the determination of total particle mass, TSP and FP filters (sample and blanks) were weighed $\left(\mathrm{CAHN}^{\circledR}\right.$ micro-balance; $\left.\mathrm{RH}<50 \%\right)$ prior to extraction and subsequent IC analysis. The FP, SFU and two of the four BCIs were analyzed for saccharides, amino acids and proteins using novel ultrafiltration/LC-MS/MS (Gao et al., 2010) and HRGC-HRMS techniques.
Sub-micrometer aerosol non-refractory chemical composition (mass). A C-ToF-AMS (Aerodyne Research Inc.) measured the bulk sub-micrometer aerosol non-refractory chemical composition of sulfate, nitrate, organics and MSA. The standard range quoted is $D_{50}: 70-700 \mathrm{~nm}$ EAD sampling efficiency, averaged over $5 \mathrm{~min}$ intervals. This is the first time that such highly time-resolved bulk chemical measurements have been made in the boundary layer of the central Arctic Ocean. The instrument sampled from the $\mathrm{PM}_{10}$ inlet with a flow rate of $\sim 100 \mathrm{~cm}^{3} \mathrm{~s}^{-1}$. For blank measurements a filter was put in the line daily. Ionization efficiency calibrations were performed about once every week. Particles entered the C-ToF-AMS through a $100 \mu \mathrm{m}$ critical orifice at 2 torr and passed through a series of aerodynamic lenses, which both focus the particles into a beam and accelerate them into a vacuum chamber. Subsequently, particles impact on a resistively heated ceramic oven, which flash-vaporizes the nonrefractory components of the aerosol at $870 \mathrm{~K}$ and $10^{-7}$ torr. The resulting gaseous compounds are ionized by electron impact $(70 \mathrm{eV})$ and detected with a unit mass resolution timeof-flight mass spectrometer. Specific details on the general operation of the C-ToF-AMS during ASCOS can be found in in Chang et al. (2011).

Chemical mapping of single particles. The determination of chemical properties, morphology and state of mixture of individual particles both in air and in aqueous phase is common to many scientific objectives. One of the two methods deployed captured the airborne particles by impaction or electrostatic precipitation using TEM and SEM. Aerosol samples were collected off the $\mathrm{PM}_{10}$ inlet directly onto the formvar surfaces of $3 \mathrm{~mm}$ copper grids. Two different impactors were used. Estimated $50 \%$ collection efficiency cut points were $\sim 200 \mathrm{~nm}$ and $\sim 70 \mathrm{~nm}$ diameter, respectively. An electrostatic precipitator was used in addition to the impactors. Particle charges were imparted at the inlet by a ${ }^{63} \mathrm{Ni}$ $\beta$-emitting radioactive source and particles were precipitated by a $12 \mathrm{kVcm}^{-1}$ electric field between the inlet and the collecting surface. Flow rate was kept very low $\left(0.17 \mathrm{~mL} \mathrm{~s}^{-1}\right)$ in order to collect particles up to $D_{50} \sim 1 \mu \mathrm{m}$. The collection efficiency of the electrostatic precipitator was intercompared with the TSI 3089 Nanometer Aerosol Sampler $\left({ }^{63} \mathrm{Ni}\right.$ $\beta$-emitting radioactive source and sample flow of $1 \mathrm{Lm}^{-1}$ ) mounted side by side with the electrostatic precipitator. Both collected a small but statistically significant number of particles $D_{50}<25 \mathrm{~nm}$.

Information on the state of mixture and morphology of the collected particles was obtained in the laboratory after the expedition by photographing individual particles after being examined by TEM/SEM. Before being examined in the TEM, grids were "shadowed" or coated with a thin platinum film ( $<1 \mathrm{~nm}$ thick) laid down by vacuum evaporation at an angle of $26^{\circ}$ to the surface. The purpose is to provide threedimensional structure and to preserve a replica of particles that evaporate, either in the high vacuum of the microscope or when heated by the electron beam. One further advantage 
with coating is to increase contrast to minimize errors concerning losses on electron-lucent particles during the subsequent digital image analysis. The electron beam intensity can be increased during examination of the grids in order to assess the volatility of particles. To test for organic components, specimens are subjected to water-insoluble vapors. One additional method is to float the grid on an aqueous solution containing a reagent that will react with specific functional groups. Ions are then exchanged through a plastic supporting membrane, allowing the reaction to proceed. Using the X-ray backscatter facility of the TEM/SEM, complementary elemental analysis of un-shadowed specimen was carried out. TEM/SEM examination is not primarily a quantitative method - obtaining statistics of the proportion of particles having a particular property is very time-consuming. To obtain quantitative information from the grid images, digital image analysis (Coz and Leck, 2011) was used.

The second method used to measure the chemical composition of single particles used a TSI TMInc $3800-100$ ATOFMS: an instrument making real-time measurements of both the aerodynamic size $\left(200 \mathrm{~nm}<D_{50}<3000 \mathrm{~nm}\right)$ and single particle composition. A comprehensive description of the instrument can be found in Gard et al. (1997) and Prather et al. (1994). The ATOFMS comprises two distinct regions: the initial sizing region followed by the mass spectrometry region. Both regions are kept under vacuum and the flow of aerosol into the instrument controlled by a critical orifice at $0.1 \mathrm{~L} \mathrm{~min}^{-1}$. The aerosol sample enters an aerodynamic focusing lens, which concentrates the sample into a $1 \mathrm{~mm}$-wide beam with particles ranging in speed from 40 to $200 \mathrm{~m} \mathrm{~s}^{-1}$, before it enters the sizing region. Sizing is carried out by two continuous wave lasers $(532 \mathrm{~nm}, 50 \mathrm{~mW})$, the circuit being triggered when a particle passes the first laser and stopped when it passes the second. As a particle intersects each laser beam, the light it scatters is detected by a photon multiplier; thus particles can only be sized if their diameter is sufficient to scatter light above a threshold. In practice this imposes a lower size limit of $100 \mathrm{~nm}$ EAD. The timing circuit is also used to trigger the Nd:YAG UV (266) ablation laser (5 ns pulse length, maximum pulse power $5 \mathrm{~mJ}$ ). The induced desorption/ionization produces both positive and negative ions that are drawn into two separate mass spectrometry regions for classification.

Inferred size-resolved aerosol composition and mixing by thermal analysis. The inferred chemical composition and mixing state of the atmospheric aerosol was determined from the thermal behavior of the bulk aerosol population. The instrumentation consists of a PCASP, size range $100 \mathrm{~nm}<D_{50}<9 \mu \mathrm{m}$, preceded by a microprocessor controlled $500 \mathrm{~W}, 4 \mathrm{~mm}$ inner diameter, $20 \mathrm{~cm}$-long tube heater: the PCASP generates a continuous $1 \mathrm{~Hz}, 32$-channel aerosol size spectrum with a sample flow of $0.18 \mathrm{~L} \mathrm{~min}^{-1}$. The temperature of the tube heater is controlled in a 15 min measurement cycle of a $90 \mathrm{~s}$ heating period, during which the heater temperature is raised from room temperature to $750^{\circ} \mathrm{C}$, fol- lowed by a 13.5 min cooling period, during which the heater temperature is returned linearly to room temperature. The cooling rate of approximately $1^{\circ} \mathrm{C} \mathrm{s}^{-1}$ ensures that thermodynamic equilibrium between the heater environment and the aerosol is achieved within the hydrodynamic entry length of the heater; a full hydrodynamic and thermodynamic analysis of the volatility heater system can be found in Brooks et al. (2002).

The underlying principle behind the thermal analysis of aerosol is that changing the temperature of an aerosol population results in changes in either the size or the number of aerosol particles, or both. The temperature at which transitions occur gives the composition, and the manner in which the transitions occur provides insight into the mixing state (external or internal). For the cooling portion of the heating cycle, the mean aerosol size spectrum in discreet temperature bands is determined, and the difference spectra between bands is used to define the composition spectrum. The composition types are defined as follows: ambient mean room temperature spectrum $\left(T<100^{\circ} \mathrm{C}\right)$; Type 1 is loss of compounds within the temperature range $100^{\circ} \mathrm{C}$ $<T<300^{\circ} \mathrm{C}$; Type II within the temperature range $300^{\circ} \mathrm{C}$ $<T<400^{\circ} \mathrm{C}$; Type III within $400^{\circ} \mathrm{C}<T<580^{\circ} \mathrm{C}$; Type IV at $580^{\circ} \mathrm{C}<T<620^{\circ} \mathrm{C}$; and Type $\mathrm{V}$ is compounds remaining at $T>620^{\circ} \mathrm{C}$. For the determination of aerosol composition and mixing in the size range $20 \mathrm{~nm}<D_{50}<800 \mathrm{~nm}$ by thermal analysis, the same principle of operation outlined above was applied. In this case, $500 \mathrm{~W}, 20 \mathrm{~mm} \mathrm{ID,} 20 \mathrm{~cm}$-long tube heater precedes a TSITM SMPS (long column and 3762 CPC). A $2.5 \mathrm{~min}$ SMPS scan time is used, however, discrete temperature steps $\left(25,50,100,200,300,400,500\right.$ and $\left.600^{\circ} \mathrm{C}\right)$ rather than a ramped temperature regime are employed.

Lead-210 and Beryllium-7. In order to indicate the time since air was last in contact with land, the radioactive decay product of ${ }^{222} \mathrm{Rn},{ }^{210} \mathrm{~Pb}$, can be used. Located on the seventh deck of Oden, high-volume aerosol samples were collected onto glass fiber filters (Munktell MGA) with a flow rate of ca $140 \mathrm{~m}^{3} \mathrm{~h}^{-1}$ for $24 \mathrm{~h}$ at a time. Six months after the sampling, the exposed filters and the field blanks were assayed for ${ }^{210} \mathrm{~Pb}$ in the laboratory with an automatic alpha/beta analyzer (Mattsson et al., 1996). ${ }^{210} \mathrm{~Pb}$ activity content of the filters was calculated from the in-grown ${ }^{210} \mathrm{Po}$ activity, which was assayed with alpha counting. ${ }^{7} \mathrm{Be}$ was determined on the same filters using semiconductor gamma spectrometry.

Heavy metals. $\mathrm{PM}_{10}$ particle samples were collected onto Teflon filters with $24 \mathrm{~h}$ sampling periods. In the laboratory the filters were wet digested and analyzed for trace metals using ion-coupled plasma mass spectrometry (ICP-MS).

$P A H$ compounds. $\mathrm{PM}_{10}$ particle samples were collected onto Teflon filters with $24 \mathrm{~h}$ sampling periods. Aerosol particles on the filters were Soxhlet extracted and analyzed for polycyclic aromatic hydrocarbons (PAH compounds, e.g., benzo $(\alpha)$ pyrene) using a gas chromatograph with a mass detector. 


\section{A2.3 Atmospheric aerosol - physical and cloud proper- ties (Table A8)}

Open lead-aerosol flux system and near-surface profiles of aerosol number. Turbulent aerosol number fluxes (as well as fluxes of momentum and sensible and latent heat) were measured directly by the eddy covariance technique at the edge of an open lead, at a height of $2.5 \mathrm{~m}$ (Held et al., 2011a, Table A3). The open lead flux system consisted of a sonic anemometer, an open path analyzer for carbon dioxide and water vapor, and a TSI ${ }^{\mathrm{TM}}$ CPC $3760 \mathrm{~A}$ condensation particle counter for particle number measurements, with nominal lower and higher cutoff diameters, $D_{50}$, of 11 and $\sim 3 \mu \mathrm{m}$, respectively. The response time of the particle counter, including the sampling line, was approximately $1.4 \mathrm{~s}$.

Near-surface profiles of aerosol number concentration and temperature were also measured using a gradient-pole technique, where the pole was positioned on a tripod so that its inlet could be lifted to different heights. The inlet was positioned manually with a repeatable accuracy of $\pm 1 \mathrm{~cm}$ between the surface and a maximum height of $1.6 \mathrm{~m}$; see Held et al. (2011b) for a detailed description.

Aerosol size distribution. Particle size distribution, from $3 \mathrm{~nm}$ to $10 \mu \mathrm{m}\left(D_{50}\right)$, was continuously monitored with a time resolution of 10-20 min sampled off the $\mathrm{PM}_{10}$ inlet. Two DMAs were deployed to measure the number size distributions of dry sub-micrometer particles. The counters used in the TDMPS (Birmili et al., 1999) were size and concentration calibrated against an electrometer and the $\mathrm{TSI}^{\mathrm{TM}}$ 3025 (Stolzenburg, 1988). The two DMA-based spectrometers were working in parallel with overlapping size ranges: a $\mathrm{TSI}^{\mathrm{TM}}-3025 \mathrm{CPC}$ was used for $3 \mathrm{~nm}<D_{50}<20 \mathrm{~nm}$ and a TSI ${ }^{\mathrm{TM}}-3020 \mathrm{CPC}$ for $10 \mathrm{~nm}<D_{50}<800 \mathrm{~nm}$. The total size range was scanned in 45 size steps with 10 min time resolution. To extend the above characterization to include particles at sizes with $D_{50}>800 \mathrm{~nm}$, a Grimm EDM 180 Environmental dust monitor $\left(250 \mathrm{~nm}<D_{50}<10 \mu \mathrm{m}\right)$ was connected at the very beginning of the $\mathrm{PM}_{10}$ inlet line, as it entered the aerosol container. This is a 32-channel, $1.2 \mathrm{~L} \mathrm{~min}^{-1}$ optical aerosol spectrometer, producing a size spectrum every $6 \mathrm{~s}$. To check for possible inlet losses when sampling interstitial air in low cloud or fog, an SMPS system $\left(7 \mathrm{~nm}<D_{50}<500 \mathrm{~nm}\right)$ was working in parallel with the TDMPS system. During testing the SMPS system switched between the $\mathrm{PM}_{1}$ and $\mathrm{PM}_{10}$ inlets. To extend the SMPS characterization to include particles at sizes $D_{50}>500 \mathrm{~nm}$ EAD, an APS $\left(280 \mathrm{~nm}<D_{50}<10 \mu \mathrm{m}\right.$ EAD) was also added.

In order to sample the vertical and horizontal variability of aerosol, trace gases and some meteorological parameters, 70 helicopter flights were performed totaling about $40 \mathrm{~h}$ of flight time. The aerosol particle size concentrations were measured at $1 \mathrm{~Hz}$ in several size ranges, using two condensation particle counters (UCPC, TSITM- 3025 for $D_{50}>3 \mathrm{~nm}$ and CPC, TSI ${ }^{\mathrm{TM}} 7610$ for $D_{50}>14 \mathrm{~nm}$ ) and a CLASP for $D_{50}>300 \mathrm{~nm}$; the CLASP is a fast-response optical aerosol spectrometer based on light scattering. It has a size range of approximately $300 \mathrm{~nm}<D_{50}<18 \mu \mathrm{m}$, a sample flow of $3 \mathrm{~L} \mathrm{~min}^{-1}$, and a sampling rate of $10 \mathrm{~Hz}$. The hydrodynamics of the CLASP inlet and path are such that they do not dry the aerosol. The aerosol instruments were mounted in a rack replacing the left passenger back seat in the helicopter, with a isokinetic inlet at the lower port side $\sim 2 \mathrm{~m}$ in front of the helicopter, well out of the rotor downwash at the nominal sampling true air speed of $\sim 20 \mathrm{~m} \mathrm{~s}^{-1}$, maintained manually by the pilot. Supporting meteorological information (temperature, relative humidity and pressure) was also measured at 2$3 \mathrm{~Hz}$. Helicopter flights were flown perpendicular to the wind direction, turning slightly upwind before the return flight, to ensure both that unpolluted air was sampled and to avoid contaminating measurements on board the ship.

Analyses of hygroscopic and volatility properties and oxidized organics fraction of aerosol by number using tandem differential mobility analyzers. The measurement systems used for an oxidized organic fraction detection in ultrafine and the lower end of Aitken mode (6-60 nm diameter) consisted of an O-TDMA (organic TDMA; Joutsensaari et al., 2001; Vaattovaara et al., 2005). The UFO-TDMA method (ultrafine organic TDMA; Vaattovaara et al., 2005) utilizes two DMAs in series. The first DMA selects a monodisperse sample from a polydisperse charged aerosol particle population taken from the main aerosol sampling line. This is brought to a selected subsaturated ethanol vapor environment where they can grow in size, according the composition and size. The analysis principle is based on the fact that inorganic compounds are not able to grow at 0.82 ethanol vapor saturation; however, oxidized organic particles grow very well (Vaattovaara et al., 2005). The size change is monitored with the second DMA. The ratio between the size in second and first DMA is called ethanol growth factor (EGF) or organic growth factor (OGF), which is then used to calculate a minimum organic volume fraction (OVF) for the moderately oxidized organics (see Vaattovaara et al., 2006). The selected sizes were typically $6,8,10,15,20,30,40,50$, and $60 \mathrm{~nm}$, respectively.

Hygroscopic properties of the particles were examined using an H-TDMA, sampling air from the $\mathrm{PM}_{10}$ inlet. The hygroscopic growth of individual aerosol particles with dry diameters (at relative humidity $<20 \%$ ) of mainly 31,50 , $72,108,163$ and $263 \mathrm{~nm}$, taken to a controlled humidified state, was determined. The H-TDMA consists mainly of three parts: (1) the first DMA, which selects a narrow, quasimonodisperse size range of the atmospheric aerosol at low $\mathrm{RH}$; (2) humidifiers, which condition the air to a well-defined $\mathrm{RH}$; and (3) the second DMA, which determines the change in diameter. The sheath air and the aerosol entering the second DMA were humidified separately, to the same set point, $90 \%$ RH during the entire cruise. Accurate control and monitoring of temperature, humidity and flow in the H-TDMA are needed for determination of hygroscopic growth. Ammonium sulfate validations were carried out on four occasions, 
with satisfactorily results. More details on the instrument can be found in Nilsson et al. (2009). The raw data were inverted with TDMAinv (Gysel et al., 2009).

The V-TDMA (Philippin et al., 2004) is capable of measuring number volatility distributions of thermally conditioned particles of selected monodisperse sizes within the submicrometer size range. Chemical information about residual non-volatile components (e.g., soot) within the aerosol can thus be inferred (e.g., Wehner et al., 2004; Rose et al., 2006). The V-TDMA system consists of three parts. In the first part defined particle diameters of the polydisperse aerosol population in the exhaust gas are selected with a DMA and counted with a CPC (TSI Model 3010). The particles then pass on to a conditioning unit in order to be heated to a specific temperature up to $300{ }^{\circ} \mathrm{C}$ to volatilize part or all of their material, leaving only non-volatile components at this particular temperature behind. In the last part of the system, the resulting number size distribution of the residual aerosol particles as well as of an according reference distribution at ambient $25^{\circ} \mathrm{C}$ are measured with a second DMA/CPC. The $300^{\circ} \mathrm{C}$-size distribution usually results in an altered size distribution indicated by a shift of the initial mode towards smaller particle diameters or its flattening due to evaporation processes, based on the different chemical components inherent to the aerosol. The presence of four heating units in parallel allows measurements at different heating temperatures subsequently. The V-TDMA can distinguish between particle core and covering layer if the core consists of less volatile material.

Full details of the VH-TDMA system can be found in Fletcher et al. (2007). The aerosol is first charged using a Ni63 neutralizer and then enters a diffusive drier to reduce the RH to about $15 \%$. This is followed by a preclassifying DMA, and the emerging mono-disperse aerosol passes through a chamber that can be heated to $400^{\circ} \mathrm{C}$. Half of the flow enters a second DMA, and the other half of the flow is first humidified to RH $90 \%$, then passes through a third DMA also monitored by a particle counter. The air sample was taken from the $\mathrm{PM}_{10}$ sampling line.

Determination of cloud condensation nuclei $(C C N)$. Two $\mathrm{CCN}$ counters were operated in parallel. The first counter scanned five different super-saturations between 0.1 and $0.7 \%$, with a measurement period of $30 \mathrm{~min}$ each. The settings of this counter were adjusted after each calibration, several times during the cruise. The second $\mathrm{CCN}$ counter was set to a constant super-saturation at $0.2 \%$. The instrument used to measure the $\mathrm{CCN}$ number concentration was a continuousflow stream-wise thermal gradient $\mathrm{CCN}$ counter $(\mathrm{CCNC})$ described in full detail by Roberts and Nenes (2005). The temperature determining the super-saturation of the instrument was calibrated several times during the cruise for both counters using mono-disperse ammonium sulfate particles, which have a known activation curve (Rose et al., 2008; Martin et al., 2011).
Determination of ice nuclei (IN): ice nuclei was detected with the Portable Ice Nucleation Chamber (PINC) instrument, a development of the Zurich Ice Nucleation Chamber (ZINC, Stetzer et al., 2008) IN chamber, especially constructed for field studies. ZINC is an instrument to measure heterogeneous ice nucleation on airborne particles. The concept is derived from the Continuous Flow Diffusion Chamber (CFDC) developed at Colorado State University. In contrast to the CFDC, it has a parallel-plate geometry, and is almost entirely made of aluminum.

Fog droplet characterization. A Droplet Measurement Technology FSSP was deployed on the roof of the fourth deck aerosol laboratory. This is an optical scattering instrument with a size range of $0.5 \mu \mathrm{m}<D_{50}<47 \mu \mathrm{m}$, aspirated at $24 \mathrm{~m} \mathrm{~s}^{-1}$ by an internal fan. The sample volume is aligned to points into wind and is therefore a function of the wind speed. Aerosol passing through the sample volume undergoes no drying, and combined with its size range it can be used for the detection of not only aerosol but also fog and cloud droplets and thus liquid water content.

\section{A3 Marine chemistry and biology}

The marine chemistry and biology program had three major aims: (i) to examine if the colloidal and micrometer size particles in the Arctic ocean SML are microgels and to quantify their abundance and size distribution; (ii) to characterize possible precursors of gel-forming polymers in the SML by quantifying the concentration of carbohydrates, proteins, amino acids, and lipids as well as the concentration of DMS and its precursor DMSP; and (iii) to determine the effect of in situ environmental parameters on gel assembly, equilibrium size and phase transition (UV, temperature, salinity, DMS and DMSP).

Samples were collected daily from surface water and the SML in the leads, unless freezing conditions prevented sampling of the latter. Samples for gel size and abundance, DMS, particulate and dissolved DMSP, chlorophyll $a$, particulate and total organic carbon and nitrogen, as well as amino acid, total protein and total carbohydrate content were collected. The field effort concentrated on sampling and collection, with some experimental work for gel properties; these experiments were repeated in the laboratory on Oden. Surface microlayer material was collected with two batterypowered remote-controlled catamaran-type vessels (Knulst et al., 2003) while subsurface seawater was collected by hand, with acid-cleaned Milli-Q water-rinsed containers at the lead or Ruttner samplers from the icebreaker during transit.

Cloud water was also collected with acid-cleaned Milli-Q water-rinsed polypropylene strings attached to the tethered balloon system operated at "Met Alley". Fog and aerosol samples were also collected on board Oden as described previously. Sea ice samples were collected either from newly frozen seawater or cored from the ice floe. Ice algae were 
scraped from sea ice or collected as floating mats. Surface microlayer, subsurface seawater and selected samples of cloud and fog water, as well as selected aerosol, sea ice, snow, and ice algae were sampled for some or all of the variables described below.

Total amino acids were analyzed with the fluorescamine method (Packard and Dortch 1975; Clayton et al., 1988), individual amino acids were quantified with reverse phase HPLC with precolumn orthophosphate acid derivatization (Mopper and Dawson, 1986; Keil and Kirchman, 1991), and total proteins were measured colorimetrically (Dortch et al., 1984) in the laboratory on Oden. Chlorophyll $a$ was determined according to Holm-Hansen et al. (1965). DMSP and DMS were quantified according to Matrai and Keller (1993). Lipids in microgels in seawater and microlayer samples were stained with Nile red (Greenspan and Fowler, 1985), examined by qualitative shipboard microscopy followed by quantitative flow cytometry. Particulate and dissolved polysaccharides were analyzed by the TPTZ protocol (Myklestad et al., 1997; Hung et al., 2001, 2003). Spectrophotometric determination of acidic polysaccharides was performed following Hung et al. $(2001,2003)$ in the laboratory on Oden. Post-cruise determination of monosaccharide composition was made possible using LC/MS/MS. In brief, vacuum-dried samples were hydrolyzed with $4 \mathrm{M}$ trifluoroacetic acid at $100^{\circ} \mathrm{C}$ for $2 \mathrm{~h}$. Excess trifluoroacetic acid was removed by vacuum evaporation, and the hydrolysate was further cleaned up by solid phase extraction. The hydrolysate was reconstituted in acetonitrile and water $(80: 20, v / v)$ prior to the analysis with LC/MS/MS (Gao et al., 2012).

Particulate organic carbon and nitrogen were analyzed according to the modified Dumas method while total organic carbon and total nitrogen were analyzed by high temperature combustion (Knap et al., 1996). The abundance and size distribution of microgels were determined by flow cytometry at the Institute of Systems Biology (Orellana et al., 2007), as well as fluorometrically (Chin et al., 1998; Orellana and Verdugo, 2003). All microgel samples resulting from experimental manipulations were observed with fluorescence and phase-contrast microscopy and documented and quantified with a Diagnostic Instruments Spot Pursuit 4 Meg slider digital camera on board the ship.

\section{A4 Physical oceanography}

The oceanographic measurement program was launched with the aim of (1) measuring turbulence in the upper ocean and at the ice/ocean interface and (2) measuring stratification, heat content and turbulent mixing in the upper ocean. This was achieved using a tethered free-falling microstructure turbulence profiler and eddy covariance instruments suspended in the boundary layer beneath the sea ice. In addition, spectral albedo and transmittance measurements were made both above and below the ice. The ocean measurement site was situated about $160 \mathrm{~m}$ from the ship location. A summary of the instrumentation and sampling periods is given in Table A9.

The microstructure profiling was performed using a loosely tethered free-fall profiler equipped with precision CTD sensors and a suite of turbulence sensors including two airfoil shear probes, a fast-response thermistor and a microconductivity sensor (Fer, 2006; Fer and Sundfjord, 2007). The profiler was deployed through the ice with a motorized winch; profiles were made hourly from the underside of the ice at $2 \mathrm{~m}$ depth and down to $500 \mathrm{~m}$. In total 345 profiles were obtained during the ice drift. High-resolution profiles (sampling rate $1024 \mathrm{~Hz}$ ) were processed (Sirevaag et al., 2011; Fer, 2006) to provide profiles with vertical resolutions of $10 \mathrm{~cm}$ and $50 \mathrm{~cm}$.

For measurements of ocean properties, turbulence and turbulent fluxes of heat, salt and momentum close to the iceocean interface, a mast containing three turbulent instrument clusters (TICs; McPhee, 2008) was deployed through a hole in the $1.8 \mathrm{~m}$-thick sea ice. Each TIC comprised a $5 \mathrm{MHz}$ acoustic Doppler velocimeter, which measured the 3-D velocity in a small sampling volume and fast-response temperature and conductivity sensors. All sensors were aligned at the same vertical level to make covariance estimates. In addition, a ducted conductivity sensor was mounted roughly $20 \mathrm{~cm}$ above the others to make accurate measurements of the absolute conductivity. The TICs sampled at $2 \mathrm{~Hz}$; data processing and flux calculations are described in Sirevaag et al. (2011). The turbulence mast was fixed to the ice, and the mast was aligned manually towards the mean current in the under-ice boundary layer.

Spectral albedo and transmittance were also measured with spectrally resolving radiometers (Nicolaus et al., 2010). Two sensors were installed above the surface for albedo measurements: one downward-looking and another upwardlooking. For transmittance measurements, an additional upward-looking sensor was installed $1.0 \mathrm{~m}$ under the sea ice. In total, 2410 albedo and 2325 transmittance spectra were recorded. The site was visited daily to check for leveling of the station and condensation or icing on the sensors. The data were corrected for shadow effects (Nicolaus et al., 2010). Manual measurements of snow and ice temperatures, snow thickness and texture were also made every 3 days, and observations of precipitation and changes in surface conditions were made daily at the optical measurement site, to document snow and sea-ice conditions and their changes.

A video-based bubble imaging system (Leifer et al., 2003) was suspended $0.5 \mathrm{~m}$ below a floatation ring on the surface of the water at the "Open Lead" site to obtain measurements of bubble size spectra (Table A3). Images were obtained at a rate of $20 \mathrm{~Hz}$ over $2 \mathrm{~min}$ sampling intervals every $15 \mathrm{~min}$ during periods when the Open Lead site was manned. These measurements are the first bubble size spectra to be obtained within leads in central Arctic sea ice (Norris et al., 2011). 